UNIVERSIDADE DE SÃO PAULO

FACULDADE DE FILOSOFIA, LETRAS E CIÊNCIAS HUMANAS

DEPARTAMENTO DE HISTÓRIA

PROGRAMA DE PÓS-GRADUAÇÃO EM HISTÓRIA SOCIAL

RAFAEL CESAR SCABIN

\title{
A correspondência jesuítica e a vivência religiosa dos colonos do planalto paulista $(1549-1588)$
}

(VERSÃO CORRIGIDA)

São Paulo 


\title{
A correspondência jesuítica e a vivência religiosa dos colonos do planalto paulista (1549-1588)
}

\author{
(VERSÃO CORRIGIDA)
}

Dissertação apresentada ao Programa de Pós-Graduação em História da Faculdade de Filosofia, Letras e Ciências Humanas da Universidade de São Paulo, para a obtenção do título de Mestre em História Social.

Área de Concentração: História Social.

Orientador: Prof. Dr. Carlos Roberto Figueiredo Nogueira. 
AUTORIZO A REPRODUÇÃO E DIVULGAÇÃO TOTAL OU PARCIAL DESTE TRABALHO, POR QUALQUER MEIO CONVENCIONAL OU ELETRÔNICO, PARA FINS DE ESTUDO E PESQUISA, DESDE QUE CITADA A FONTE.

Scabin, Rafael Cesar

A correspondência jesuítica e a vivência religiosa dos colonos do planalto paulista (1549-1588). / Rafael Cesar Scabin; Orientador: Professor Doutor Carlos Roberto Figueiredo Nogueira - São Paulo, 2012.

$121 \mathrm{fl}$ : fig

Dissertação (Mestrado - Programa de Pós-Graduação em História, Área de Concentração: História Social) - Faculdade de Filosofia, Letras e Ciências Humanas da Universidade de São Paulo, 2012. 
Nome: SCABIN, Rafael Cesar

Título: "A correspondência jesuítica e a vivência religiosa dos colonos do planalto paulista (1549-1588)"

Dissertação apresentada à Faculdade de Filosofia, Letras e Ciências Humanas da Universidade de São Paulo para obtenção do título de Mestre em História Social.

Aprovado em:

Banca Examinadora

Prof. Dr.

Instituição:

Julgamento:

Assinatura:

Prof. Dr.

Instituição:

Julgamento:

Assinatura:

Prof. Dr.

Instituição:

Julgamento:

Assinatura: 


\section{AGRADECIMENTOS}

Agradeço, em primeiro lugar, ao Professor Carlos Roberto Figueiredo Nogueira pela confiança e interesse com que aceitou e levou adiante a orientação da presente pesquisa. Mestre com quem compartilho o interesse pelos aspectos mais concretos e cotidianos das religiões e com quem aprendi a importante lição de que a seriedade não precisa de cara feia.

Agradeço também ao Professor Adone Agnolin pela gentileza e disposição com que atendeu às minhas impertinentes solicitações. Às professoras Raquel Glezer e Sara Albieri, integrantes da banca de qualificação, que deram sugestões indispensáveis para a estruturação dos capítulos e subitens, além de importantes indicações conceituais e bibliográficas. As disciplinas lecionadas pelas professoras Julieta Araújo, Ana Paula Megiani e Antonella Romano abriram caminhos e corrigiram deslizes. Agradeço ainda aos professores José Carlos Vilardaga, que gentilmente enviou-me uma cópia de sua tese, Carlos Alberto Zeron e Rafael Ruiz Gonzalez.

Devo, aos membros do Grupo de Estudos Medievais Portugueses (GEMPO), valiosas sugestões à pesquisa e os benefícios de um rico ambiente de debate historiográfico. Agradeço especialmente à Candice Quinelato, pela cuidadosa revisão do texto, e ao Bruno Miranda, pelo acolhimento em sua casa durante as consultas ao acervo da Biblioteca Nacional.

Em relação ao suporte pessoal, sou profundamente grato ao incentivo e auxílio dos meus pais, Luiz e Cristina Scabin, aos quais nunca poderei retribuir à altura. Agradeço a todos os amigos e parentes que estiveram presentes nesse período, principalmente Igor Koga, Lívia Sena, Leandro Aiosa e minha companheira Marília Mangueira. Finalmente, agradeço à Camila Bernardino, pela amizade e ajuda com os aspectos burocráticos da dissertação, e ao Glaumer Alves, que fez por mim nesse período mais do que se poderia esperar de um amigo. 
Aqueles que aceitam a noção da Igreja como uma instituição divina que é diferente de outras instituições devem enfrentar a dificuldade de que a história da Igreja revela de forma bastante óbvia uma mistura contínua de aspectos políticos e religiosos. [...] Em contraste, os historiadores da Igreja que a vêem como uma instituição do mundo têm de lidar com a dificuldade de descrever sem a ajuda da crença o que existiu apenas com a ajuda de uma crença. da historiografia eclesiástica". 


\section{RESUMO}

SCABIN, Rafael Cesar. A correspondência jesuítica e a vivência religiosa dos colonos do planalto paulista (1549-1588). 2012. 121 f. Dissertação (Mestrado) - Programa de PósGraduação em História Social, Faculdade de Filosofia, Letras e Ciências Humanas, Universidade de São Paulo, São Paulo, 2012.

Grande parte do que sabemos a respeito do planalto paulista no século XVI provém das cartas jesuíticas, fontes documentais de extraordinária riqueza, produzidas por meio de uma prática textual regida por parâmetros bastante específicos e parte fundamental da atividade missionária da Companhia de Jesus. Uma tradição historiográfica longa e influente buscou na correspondência jesuítica elementos que ajudaram a compor certas imagens tradicionais acerca da vida no planalto paulista colonial e das características de seus moradores, discutidas e problematizadas nas pesquisas mais recentes. Dentre estas imagens tradicionais, a ideia de que os moradores das vilas de Santo André da Borda do Campo e São Paulo de Piratininga davam pouca atenção à Igreja ou à vida cristã em geral ecoa ainda em estudos recentes. Esta ideia baseia-se na articulação entre as narrativas epistolares quinhentistas, algumas referências documentais do século posterior e o paradigma historiográfico da especificidade paulista. Entretanto, por meio de uma análise sistemática das cartas jesuíticas do século XVI, centrada na consideração de sua estrutura retórica e formal, é possível decompor estas camadas interpretativas e problematizar a prática discursiva da comunicação epistolar da Companhia de Jesus, no que se refere à vivência religiosa dos colonos do planalto paulista. Dessa forma, recupera-se a dimensão política de acusações como "indianização" dos costumes, desrespeito às autoridades ou vida pecaminosa.

Palavras-chave: São Paulo colonial, Companhia de Jesus, Epistolografia, Igreja, Interculturalidade 


\begin{abstract}
SCABIN, Rafael Cesar. The Jesuit letters and religious experience of the colonists of the Paulista Plateau (1549-1588). 2012. 121 f. Dissertação (Mestrado) - Programa de PósGraduação em História Social, Faculdade de Filosofia, Letras e Ciências Humanas, Universidade de São Paulo, São Paulo, 2012.

Much of what we know about the Paulista Plateau in the sixteenth century stems from Jesuitic letters, documentary sources of extraordinary wealth, produced through a textual practice governed by very specific parameters and fundamental part of the missionary activity of the Society of Jesus. A long and influential historiographical tradition searched elements in the Jesuitic correspondence that have helped to compose some traditional images about life in the colonial Paulista Plateau and the characteristics of its residents, which have been discussed and problematized in the latest researches. Among these traditional images, the idea that the villagers of Santo André da Borda do Campo and São Paulo de Piratininga paid little attention to the Church or the Christian life in general still echoes in recent studies. This idea is based on the articulation between the epistolary narratives of the sixteenth century, some documentary references from the subsequent century and the historiographical paradigm of paulista specificity. However, by means of a systematic analysis of the Jesuitic letters from the sixteenth-century, focused in the consideration of its formal and rhetorical structure, it is possible to decompose these interpretative layers and problematize the discursive practice of the epistolary communication of the Society of Jesus, in relation to the religious experience of the settlers of the Paulista Plateau. Thus, it is recovered the political dimension of accusations as "Indianization" of manners, disrespect for authority or sinful life.
\end{abstract}

Keywords: Colonial São Paulo, Society of Jesus, Epistolography, Church, Interculturality 


\section{LISTA DE ILUSTRAÇÕES}

Mapa 1 - Povoamento do Território Paulista no século XVI........................................... 17

Figura 1 - Assinatura de João Ramalho presente em ata da Câmara de Santo André........... 58 


\section{LISTA DE SIGLAS}

ACVSP Atas da Câmara da vila de São Paulo

ARSI Archivum Romanum Societatis Iesu

IHGB Instituto Histórico e Geográfico Brasileiro

IHGSP Instituto Histórico e Geográfico de São Paulo

MB Monumenta Brasiliae

RIHGB Revista do Instituto Histórico e Geográfico Brasileiro

RIHGSP Revista do Instituto Histórico e Geográfico de São Paulo 


\section{SUMÁRIO}

INTRODUÇÃO 11

CAPÍTULO 1: COLONOS, JESUÍTAS E ATIVIDADE EPISTOLOGRÁFICA 22

1.1. Escrita e circulação das cartas jesuíticas 23

1.2. O lugar dos colonos do planalto paulista nas cartas jesuíticas 37

1.3. O Caso de João Ramalho 53

CAPÍTULO 2: A VIVÊNCIA RELIGIOSA DOS COLONOS: INTERCULTURALIDADE E DIMENSÃO POLÍTICA___ 76

2.1. Os "costumes gentílicos" __ 77

2.2. A mancebia — 90

2.3. Administração de sacramentos __ 99

CONSIDERAÇÕES FINAIS___ 104

BIBLIOGRAFIA — 113 
INTRODUÇÃO 
A presente pesquisa teve como estímulo inicial a seguinte questão: como se dava a vivência religiosa cotidiana dos colonos paulistas durante o período inicial de ocupação portuguesa no planalto, em meio à escassa presença institucional da Igreja? Esta questão, neste formato amplo e ainda pouco desenvolvido, era animada por um interesse nas relações entre práticas religiosas populares e a ortodoxia católica ${ }^{1}$. As potencialidades do contexto paulista do século XVI para atender a esses interesses foram sugeridas, principalmente, pela leitura das obras de Sérgio Buarque de Holanda, Richard Morse e John Monteiro².

Durante a consulta bibliográfica que se seguiu, ficou imediatamente claro o papel central que a correspondência jesuítica cumpria em relação àquilo que sabemos sobre as práticas religiosas cotidianas no planalto paulista quinhentista. Esse material já foi exaustivamente lido e relido, submetido a revisões metodológicas diversas, e é quase onipresente na historiografia que trata do período colonial brasileiro. Mesmo parecendo não haver muito mais a ser dito a respeito das cartas jesuíticas, sua análise, no que se refere ao nosso tema, não parece ter acompanhado a profunda e longa revisão metodológica que se desenvolveu na abordagem de outros temas, como a escravidão indígena, a vida material no planalto paulista, os aldeamentos jesuítas ou o processo de evangelização dos nativos. Como consequência, é possível perceber na historiografia sobre o primeiro século paulista a persistência de imagens tradicionais de São Paulo e seus povoadores, ligadas a uma leitura fragmentária e pouco crítica dessas fontes.

A correspondência dos missionários jesuítas do Brasil é utilizada como fonte para a descrição da realidade americana desde a própria época de sua escrita. Giovanni Botero, no final do século XVI, valia-se desse material para descrever essa região em suas Relazioni Universali, tratado de geografia política universal ${ }^{3}$. A utilização das narrativas epistolares na composição de outros textos era corriqueira na Companhia de Jesus desde o século XVI,

\footnotetext{
${ }^{1}$ Ao mencionarmos práticas religiosas populares não partimos de uma pretensa religiosidade popular em um sentido orgânico e monolítico, como é muitas vezes assumido, mas de práticas concretas vivenciadas por um segmento social em determinado contexto, a partir de complexas relações culturais com os outros segmentos, a maior ou menor presença da Igreja constituída, entre outros fatores. Da mesma forma, consideramos a ortodoxia em seu sentido dinâmico e processual, determinada nas situações concretas da vivência religiosa e política.

${ }^{2}$ HOLANDA, Sérgio Buarque de. "Capelas antigas de São Paulo". Revista do Serviço de Patrimônio Histórico Nacional, vol. 5, Rio de Janeiro, 1941, pp.105-120;__. Caminhos e fronteiras. 3. ed. São Paulo: Companhia das Letras, 1994 [1956]; __ Raízes do Brasil. 26. ed. São Paulo: Companhia das Letras, 1995 [1936]; MORSE, Richard M. Formação histórica de São Paulo (de comunidade à metrópole). São Paulo: Difusão Européia do Livro, 1970 [1954]; MONTEIRO, John Manuel. Negros da Terra: Índios e bandeirantes nas origens de São Paulo. São Paulo: Companhia das Letras, 1994; __. Tupis, Tapuias e historiadores: Estudos de História indígena e do indigenismo. 2001. 233 f. Tese (Livre Docência em Etnologia) - Instituto de Filosofia e Ciências Humanas, Unicamp, Campinas, 2001.

${ }^{3}$ Cf. SOUZA, Laura de Mello e. Inferno Atlântico: demonologia e colonização: séculos XVI-XVIII. São Paulo: Companhia das Letras, 1993, capítulo 3, "Por fora do Império: Giovanni Botero e o Brasil", pp. 58-88.
} 
como parte da rede de leitura e circulação dessas cartas que analisaremos adiante, como acontece na obra seiscentista do jesuíta Simão de Vasconcelos. A influência também ocorria de forma indireta, como mostra o exemplo do cronista setecentista Frei Gaspar da Madre de Deus $^{4}$, que não cita diretamente as cartas, mas vale-se largamente da obra de Simão de Vasconcelos.

A partir da segunda metade do século XIX, esse uso se difundiu de maneira mais intensa, com as publicações esparsas dessa documentação pela Academia Brasileira de Letras, revistas do Instituto Histórico e Geográfico Brasileiro e do Instituto Histórico e Geográfico de São Paulo e, posteriormente, com as compilações mais sistemáticas do jesuíta Serafim Leite. A leitura realizada dessas cartas foi predominantemente narrativa, utilizando os relatos dos missionários como uma descrição relativamente objetiva do que ocorria no momento de sua redação. É a partir desse posicionamento que Serafim Leite organiza sua compilação dessa correspondência, a Monumenta Brasiliae, e suas análises históricas correspondentes. O desenvolvimento historiográfico desse critério fazia já parte da grandiosa História da Companhia de Jesus no Brasil $l^{5}$, na qual o autor apresenta um quadro descritivo da presença jesuítica no Brasil baseado principalmente nos relatos das cartas. Vitorino Nemésio sintetiza emblematicamente essa metodologia de leitura das cartas ao prefaciar seu próprio estudo dessa documentação:

[...] procurei trabalhar o mais possível directamente sobre o epistolário dos Padres e Irmãos, preferindo fazê-los falar a eles mesmos dos seres e das coisas da sua formidável experiência a narrá-la eu por minha conta. [...] a ponto de que, nas duas partes finais deste livro, mais pareço um notário de públicas-formas do que um historiador narrativo. Mas o tom da palavra de tais homens é tão forte e sincero que nos convida ao silêncio ${ }^{6}$.

A partir de meados do século XX, essa leitura factual-narrativa das cartas perdeu espaço na historiografia, que passou a privilegiar a retirada tópica de informações relativas a vida material, ocupação do espaço, conflitos entre colonos e indígenas e a análise das características da atuação missionária. Para o caso de São Paulo colonial, que aqui nos interessa, os trabalhos de John Monteiro, Sérgio Buarque de Holanda e Richard Morse ${ }^{7}$ são

\footnotetext{
${ }^{4}$ MADRE DE DEUS, Frei Gaspar da. Memórias para a história da Capitania de S. Vicente, hoje chamada de S. Paulo, do Estado do Brazil. Lisboa: Tipographia da Academia, 1797.

${ }^{5}$ LEITE, Serafim, S. J. História da Companhia de Jesus no Brasil, tomos I e II. Lisboa: Livraria Portugália; Rio de Janeiro: Civilização Brasileira, 1938.

${ }^{6}$ NEMÉSIO, Vitorino. O campo de São Paulo: A Companhia de Jesus e o plano português do Brasil. $3^{\mathrm{a}}$ ed. Lisboa: Secretaria de Estado da Informação e Turismo, 1971 [1954], p. XIII.

${ }^{7}$ MONTEIRO, John Manuel. Negros da Terra: Índios e bandeirantes nas origens de São Paulo. São Paulo: Companhia das Letras, 1994; Tupis, Tapuias e historiadores: Estudos de História indígena e do indigenismo. 2001. 233 f. Tese (Livre Docência em Etnologia) - Instituto de Filosofia e Ciências Humanas,
} 
exemplos representativos desse tipo de leitura documental. Ainda que essa utilização das cartas nem sempre dispensasse atenção suficiente aos seus condicionantes formais e institucionais, a retirada de informações era realizada em conjunto com uma série documental muito mais extensa e de diversa natureza, o que permitia uma avaliação bastante mais crítica. Não pretendemos em nossa pesquisa questionar essa leitura documental das cartas, que nos parece pertinente, nem tampouco desconsiderar que haja um aspecto objetivo nas informações nelas presentes. Apenas buscamos mostrar, por meio da metodologia que propomos, apresentada mais à frente, que essa leitura fragmentária e relativamente objetiva não apresenta sempre a mesma eficácia, podendo ser mais problemática quando utilizada para determinados temas e sem levar em conta o tipo de carta de que se tratava e as relações envolvidas em sua escrita.

Os estudos mais recentes apresentam ainda outras maneiras de utilizar a correspondência jesuítica como fonte documental. Há a análise de sua estrutura formal e retórica, como as desenvolvidas por João Adolfo Hansen ${ }^{8}$ e Alcir Pécora ${ }^{9}$; das relações intertextuais dessa epistolografia, como a realizada por Adriana Cerello ${ }^{10}$; de seu conteúdo teológico, como, por exemplo, o estudo de Laura de Mello e Souza sobre a relação desses relatos missionários com a demonologia europeia ${ }^{11}$; e de seus elementos simbólicos, como Luis Augusto Bicalho Kehl desenvolve a respeito dos eventos que envolveram a fundação da casa de São Paulo de Piratininga ${ }^{12}$. A utilização pontual de trechos dessa correspondência é constante na historiografia referente ao período colonial brasileiro, mas há trabalhos recentes nos quais essas cartas são analisadas mais sistematicamente. José Eisenberg investiga nas cartas a emergência de concepções políticas, na discussão da organização missionária, que repercutem no desenvolvimento do pensamento político europeu ${ }^{13}$. Em relação ao tema da

Unicamp, Campinas, 2001, especialmente o capítulo 2; HOLANDA, Sérgio Buarque de. "Capelas antigas de São Paulo". Revista do Serviço de Patrimônio Histórico Nacional, vol. 5, Rio de Janeiro, 1941, pp.105-120; MORSE, Richard M. Formação histórica de São Paulo (de comunidade à metrópole). São Paulo: Difusão Européia do Livro, 1970 [1954].

${ }^{8}$ HANSEN, João Adolfo. "O nu e a Luz: Cartas jesuíticas do Brasil. Nóbrega, 1549-1558”, Revista do Instituto de Estudos Brasileiros, São Paulo, n. 38, 1995, pp. 87-119.

9 PÉCORA, Alcir. "Arte das Cartas jesuíticas do Brasil". In: ENCONTRO INTERNACIONAL NÓBREGAANCHIETA, 1999, São Paulo. VOZ LUSÍADA. Anais do Encontro Internacional Nóbrega-Anchieta. São Paulo: Green Forest do Brasil, 1999, v. 1, p. 31-78.

${ }^{10}$ CERELLO, Adriana Gabriel. O livro nos textos jesuíticos do século XVI: edição, produção e circulação de livros nas cartas dos jesuítas na América Portuguesa (1549-1563). 2007. 143 f. Dissertação (Mestrado em Literatura Brasileira) - Faculdade de Filosofia, Letras e Ciências Humanas, Universidade de São Paulo, São Paulo, 2007.

${ }^{11}$ SOUZA, Laura de Mello. Inferno Atlântico: demonologia e colonização: séculos XVI-XVIII. São Paulo: Companhia das Letras, 1993.

12 KEHL, Luis Augusto Bicalho. Simbolismo e profecia na fundação de São Paulo: A casa de Piratininga. São Paulo: Editora Terceiro Nome, 2005.

${ }^{13}$ EISENBERG, José. As missões jesuíticas e o pensamento político moderno: Encontros culturais, aventuras 
escravidão, Carlos Alberto de M. R. Zeron realiza uma profunda revisão na maneira de se abordar a documentação jesuítica ${ }^{14}$. O autor problematiza o discurso institucional da ordem que, principalmente por meio das cartas, dissemina a imagem da Companhia como defensora da liberdade indígena. Desta forma, realiza por intermédio de uma leitura crítica e sistemática dessa correspondência, além do cotejamento com outras fontes, uma ampla análise da relação concreta e cotidiana dos jesuítas com a escravidão, para além do discurso institucional, longamente reafirmado pela historiografia por meio da utilização acrítica da documentação jesuítica.

Uma série de trabalhos recentes tem contribuído de forma capital para uma utilização crítica não apenas das cartas jesuíticas, mas da documentação missionária em geral. São pesquisas, inseridas no diálogo entre a História e a Antropologia, que têm se dedicado a analisar os mecanismos por meio dos quais se desenvolve uma cultura colonial com produção de códigos compartilhados nos contatos entre jesuítas e indígenas ${ }^{15}$. O foco desses trabalhos é principalmente o encontro entre as civilizações americanas e a europeia, e o necessário processo de mediação cultural que se estabelece na relação concreta de convivência (sem excluir a violência nela presente); mediação que se dá preferencialmente por meio de uma interpretação religiosa da diversidade cultural $^{16}$. Nesse sentido, as missões são um espaço privilegiado de análise, no qual é possível identificar a "civilização cristã em ação" ${ }^{17}$. De grande importância para nossa pesquisa é o desenvolvimento, nesses trabalhos, de uma metodologia de leitura da documentação missionária que permite apreender não apenas a subjetividade de quem a produz, mas também relações concretamente estabelecidas.

O objetivo de nossa pesquisa é reavaliar o que se pode afirmar sobre a vivência religiosa dos primeiros paulistas a partir da correspondência jesuítica no período em que a única presença institucional da Igreja no planalto era a da Companhia de Jesus, submetendo essas cartas a uma leitura sistemática que considere seus aspectos retóricos e formais. Dessa maneira, poderemos fornecer um enfoque diferenciado à investigação dessa temática, que

\footnotetext{
teóricas. Belo Horizonte: Ed. UFMG, 2000.

${ }^{14}$ ZERON, Carlos Alberto de M. R. Ligne de foi: La compagnie de Jésus et l'esclavage dans le processus de formation de la société coloniale en Amérique portugaise (XVIe-XVIIe siècles). Paris: Honoré Champion Éditeur, 2009.

${ }^{15}$ MONTERO, Paula (org.). Deus na Aldeia: missionários, índios e mediação cultural. São Paulo: Globo, 2006; AGNOLIN, Adone. Jesuítas e Selvagens: A negociação da fé no encontro catequético-ritual americano-tupi (séc. XVI - XVII). São Paulo: Humanitas Editorial, 2007; POMPA, Cristina. Religião como tradução: missionários, Tupi e "Tapuia" no Brasil colonial. Bauru: EDUSC, 2003.

${ }^{16}$ Essa problemática é o cerne do fundamental trabalho de Cristina Pompa, op. cit.

${ }^{17}$ GASBARRO, Nicola. "Missões: a civilização cristã em ação". In: MONTERO, Paula (org.), op. cit.
} 
consideramos ainda muito influenciada pelas construções historiográficas desenvolvidas entre a segunda metade do século XIX e meados do século XX.

A opção pelo termo vivência religiosa, propiciador de não poucas dificuldades, requer uma explicação mais detida. Ao longo da pesquisa, avaliamos a pertinência de aplicar ao objeto em questão os termos práticas religiosas, observância religiosa, religiosidade, entre outros. Ainda que o conceito de vivência religiosa não nos deixe plenamente satisfeitos, evita, quando devidamente definido, os problemas conceituais presentes nos demais termos, como a insuficiente historicização existente no conceito de religiosidade e a ligação do conceito de observância religiosa com o pertencimento a uma ordem religiosa. Com o objetivo de apreender a religião em sua historicidade ${ }^{18}$, optamos pela utilização de vivência religiosa, destacando o aspecto cotidiano, mas não exclusivamente litúrgico e ritual, da experiência religiosa dos colonos do planalto paulista, perspectiva esta que poderia não ser alcançada optando-se por práticas religiosas. No entanto, o termo vivência não se relaciona, em nossa pesquisa, à subjetividade da experiência religiosa dos colonos. Em outras palavras, nosso enfoque não se direciona ao entendimento que esses habitantes tinham do que seria ou não religioso em práticas como a mancebia, a poligamia ou a adoção de costumes indígenas rituais ou não. O nosso recorte temático parte do viés religioso com que a escrita jesuítica abordava diversos aspectos da vida cotidiana dos colonos, para assim problematizar essa própria perspectiva. Interessa-nos compreender sob quais critérios teológico-políticos e relações concretas de convivência definiu-se o campo do religioso naquele contexto. Como veremos adiante, a classificação religiosa de fenômenos como a mancebia e os costumes indígenas, além de bastante flexível, respondia a conflitos políticos específicos.

O período de exclusividade pastoral da Companhia no planalto paulista estende-se até 1588, data da criação da paróquia de São Paulo, que assinala o fim do período em que a presença institucional do catolicismo na região resumia-se aos inacianos, únicos aptos a administrar os sacramentos e celebrar missas, sendo a igreja do colégio jesuítico a única existente $^{19}$. Partimos da data inicial de 1549 , ano da chegada do primeiro grupo de jesuítas ao Brasil e das primeiras comunicações epistolares; a primeira referência ao campo de

\footnotetext{
${ }^{18}$ Para uma problematização da historicidade do conceito de religião, além dos trabalhos anteriormente citados acerca da mediação cultural, cf. MASSENZIO, Marcello. A história das religiões na cultura moderna. São Paulo: Hedra, 2005; BRELICH, A. "Prolegómenos a una historia de las religiones". In: PUECH, Henri-Charles (org.). Historia de las religiones, vol. 1: Las religiones antiguas I. $6^{a}$ ed. Madrid: Siglo XXI, 1986, pp. 30-97.

${ }^{19}$ WERNET, Augustin. "Vida religiosa em São Paulo: do Colégio dos jesuítas à diversificação de cultos e crenças (1554-1954)". In: PORTA, Paula (org.). História da Cidade de São Paulo, v.1: a cidade colonial. São Paulo: Paz e Terra, 2004, p. 194; LEITE, Serafim. História da Companhia de Jesus no Brasil, tomo I. Lisboa: Livraria Portugália; Rio de Janeiro: Civilização Brasileira, 1938, pp. 312-3.
} 
Piratininga nas cartas deu-se no ano seguinte. Dados o período e as problemáticas que nos ocupam, abordamos conjuntamente as vilas de Santo André da Borda do Campo e de São Paulo, resultado da transferência da primeira para o sítio do colégio jesuítico. Uma vez que tratamos dos colonos, a data de fundação da casa de São Paulo pelos jesuítas é, no âmbito de nossa pesquisa, menos relevante que o anterior estabelecimento da população branca no planalto, primeiramente em Santo André e posteriormente transferida para junto do Colégio. Valemo-nos do termo planalto paulista para designar a região compreendida pelas duas vilas (não contemporâneas) e as escassas áreas ao seu redor ocupadas por roças e aldeamentos jesuítas. Lembramos, nesse sentido, que a documentação jesuítica quinhentista é muitas vezes imprecisa ao informar a localização de seus assentamentos na região ${ }^{20}$.

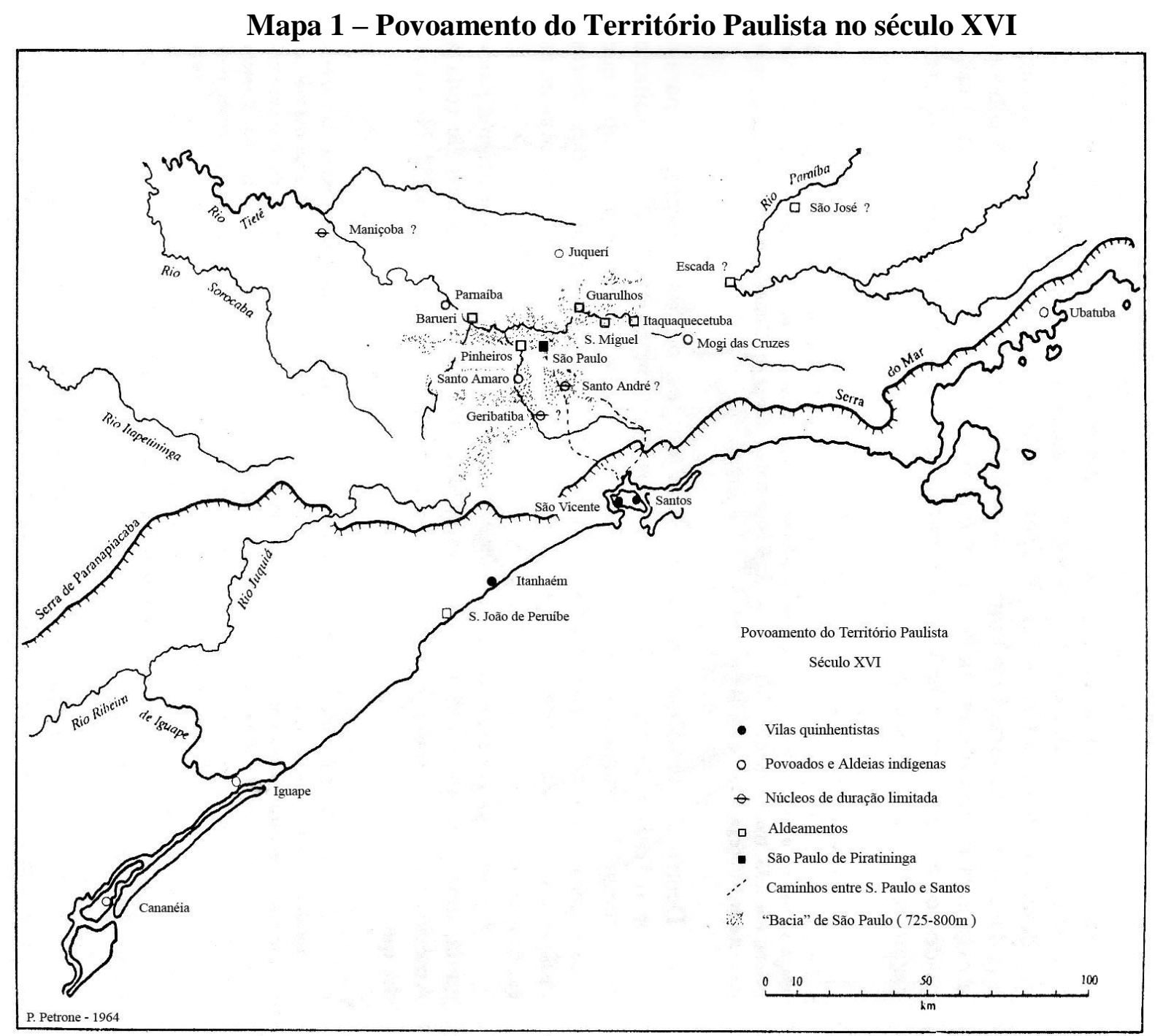

Fonte: PETRONE, Pasquale. Aldeamentos paulistas. São Paulo: Edusp, 1995, p. 47.

\footnotetext{
${ }^{20}$ PETRONE, Pasquale. Aldeamentos paulistas. São Paulo: Edusp, 1995, p. 107.
} 
Os colonos ocupam na correspondência jesuítica um lugar marginal, restrito a alguns aspectos específicos de sua presença na realidade colonial. Dessa forma, consideramos problemático e temerário tentar recompor um quadro factual do cotidiano religioso dos moradores das vilas do planalto a partir dessa documentação. Nossa abordagem consiste na análise sistemática desses aspectos mais citados, como a prática da mancebia, a recepção de sacramentos e a adoção de costumes indígenas, respeitando e delimitando melhor as lacunas existentes nessas fontes. A análise, ainda que parcial, das práticas religiosas dos colonos passa também pela melhor delimitação de tais lacunas, visto que as imagens construídas ao longo dos séculos XIX e XX sobre a vida no planalto basearam-se, em certa medida, em especulações e generalizações ocasionadas pela limitação documental. É a partir dessa consideração que abordamos os temas fragmentariamente citados nas cartas, como a realização de procissões e o presumido descaso dos mamelucos para com o Santo Ofício.

Nossa proposta de leitura da correspondência jesuítica baseia-se na recondução dos trechos sobre os colonos à totalidade retórica e formal desses textos. Consideramos que as passagens em questão somente podem ser compreendidas em sua historicidade se forem contextualizadas no exercício retórico de sua escrita. Analisar o procedimento formal de escrita das cartas não representa em nossa pesquisa um exercício de comparação estilística ou um alargamento do tema para questões de gênero de escrita. Entender a estrutura retórica e formal desse tipo de documento é essencial para considerar seu conteúdo. Como afirma João Adolfo Hansen, "[as maneiras do discurso] não são mera técnica aplicada do exterior, mas categorias de pensamento que modelam a forma mentis dos agentes da correspondência"21. Alcir Pécora também não considera a análise formal apenas um elemento dentre outros a ser estudado nas cartas. Para ele, a abordagem formal tem uma implicação epistemológica:

[...] o de que elas [as cartas] não são absolutamente uma tábua em branco impressionada por acontecimentos vividos pelos missionários - nem objetivamente, como representação ou notícia da gente e terra do Brasil; nem subjetivamente, como impacto sentimental ou expressivo dessa notícia em certa mentalidade católica européia [...], devem ser vistas, antes de mais nada, como um mapa retórico em progresso da própria conversão. [...]De tal modo que as determinações convencionais da tradição epistolográfica, revistas pela Companhia e aplicadas aos diversos casos vividos, mesmo os mais inesperados, sedimentam sentidos adequados aos roteiros plausíveis desse mapa ${ }^{22}$.

\footnotetext{
${ }^{21}$ HANSEN, João Adolfo "O nu e a Luz: Cartas jesuíticas do Brasil. Nóbrega, 1549-1558”, Revista do Instituto de Estudos Brasileiros, São Paulo, n. 38, 1995, p. 88.

${ }^{22}$ PÉCORA, Alcir. "Arte das Cartas jesuíticas do Brasil". In: ENCONTRO INTERNACIONAL NÓBREGAANCHIETA, 1999, São Paulo. VOZ LUSÍADA. Anais do Encontro Internacional Nóbrega-Anchieta. São Paulo: Green Forest do Brasil, 1999, v. 1, p. 31-32.
} 
$\mathrm{Na}$ presente pesquisa, portanto, ao analisarmos a construção do discurso jesuítico sobre as práticas religiosas dos colonos do planalto paulista, não pretendemos destacar apenas o aspecto subjetivo dessa documentação. Como alerta Paula Montero, além do risco de ler objetivamente as informações presentes na documentação missionária, há também o risco oposto de assumir que desses textos não podemos tirar nada além do próprio discurso jesuítico $^{23}$. A epistolografia jesuítica não é apenas uma descrição da ação missionária, é também parte fundamental dessa ação ${ }^{24} \mathrm{e}$, como tal, cristaliza relações concretamente estabelecidas $^{25}$, que só podem ser devidamente observadas se considerarmos os filtros subjetivos que orientam a escrita. Um bom exemplo de aplicação desta premissa epistemológica encontra-se, como já dissemos, na utilização da documentação jesuítica efetuada por Cristina Pompa ${ }^{26}$. Estas premissas metodológicas estão direcionadas para a análise do encontro cultural entre missionários e indígenas, mas são também essenciais para nosso tema. Primeiramente, porque a descrição dos colonos aparece nas cartas quase sempre subordinada ao tema da evangelização do indígena e é no interior dessa relação concreta que devemos considerá-la. Em segundo lugar, ainda que não devamos exagerar a oposição entre missionários e colonos, como fez certa historiografia, as relações muitas vezes conflituosas entre eles também se cristaliza na documentação, não nos permitindo reduzir as informações apenas a um discurso jesuíta sobre o colono.

De acordo com nossa proposta, a dissertação divide-se em dois capítulos. Não é uma divisão rígida, mas que se faz necessária para uma maior clareza expositiva. $\mathrm{O}$ primeiro capítulo analisa a prática epistolográfica da Companhia em seus aspectos mais amplos, identificando o papel que as narrativas sobre os colonos cumpriam nesse processo de escrita, enquanto o segundo capítulo detém-se na análise pormenorizada dos aspectos mais específicos da vivência religiosa dos colonos do planalto paulista de acordo com a maneira como aparecem nas cartas. Uma vez que propomos analisar as descrições a respeito dos moradores das vilas de Santo André da Borda do Campo e de São Paulo na totalidade de cada carta, o primeiro capítulo não apenas dá sentido ao segundo, mas muitas vezes eles acabam por se interpenetrar. Como exemplo dessa permeabilidade do texto, temos o item sobre o caso

\footnotetext{
${ }^{23}$ MONTERO, Paula. "Introdução". In: (org.). Deus na Aldeia: missionários, índios e mediação cultural. São Paulo: Globo, 2006, pp. 12-13.

${ }^{24}$ PÉCORA, Alcir. "Arte das Cartas jesuíticas do Brasil”. In: ENCONTRO INTERNACIONAL NÓBREGAANCHIETA, 1999, São Paulo. VOZ LUSÍADA. Anais do Encontro Internacional Nóbrega-Anchieta. São Paulo: Green Forest do Brasil, 1999, v. 1, p. 32; EISENBERG, José. As missões jesuíticas e o pensamento político moderno: Encontros culturais, aventuras teóricas. Belo Horizonte: Ed. UFMG, 2000, p. 49.

${ }^{25}$ MONTERO, op. cit., p. 11 et seq.

${ }^{26}$ POMPA, Cristina. Religião como tradução: missionários, Tupi e "Tapuia" no Brasil colonial. Bauru: EDUSC, 2003.
} 
de João Ramalho, que se situa no primeiro capítulo, ponto três, mas que poderia igualmente localizar-se no segundo capítulo, já que inclui praticamente todas as problemáticas que fazem parte do trabalho.

Para o desenvolvimento da presente pesquisa, optamos por utilizar a já citada coletânea Monumenta Brasiliae, realizada pelo jesuíta Serafim Leite, entre os anos de 1956 e 1968. Trata-se do trabalho de compilação mais sistemático, pormenorizado e completo das cartas jesuíticas do Brasil. A publicação é divida em cinco volumes, dos quais utilizamos os quatro primeiros $^{27}$, que contêm documentação referente ao período de 1538 a 1568.

Prestando o devido reconhecimento ao extenso e cuidadoso trabalho realizado por Serafim Leite, de fundamental importância para todos os pesquisadores que se lhe seguiram, é preciso, no entanto, explicitar os critérios que orientaram sua compilação, uma vez que não são os mesmos em que se fundamenta nossa leitura dessa documentação.

A coletânea Monumenta Brasiliae possui, como dissemos, um caráter fundamentalmente narrativo, que influencia a seleção, a organização e a edição dos documentos. A inclusão, nesta compilação, de documentação exterior à ordem, como as cartas de D. João III ou da Câmara da vila de São Paulo, relaciona-se de forma complementar às cartas da Companhia, fornecendo informações que preencheriam um quadro cronológico e factual dos acontecimentos referentes à atuação dos jesuítas no processo de colonização. Também a publicação parcial de algumas cartas da ordem, com a indicação "edita-se o que toca ao Brasil", repetida durante toda a compilação, bem como a natureza das notas explicativas de Serafim Leite, indicam a prevalência do critério narrativo sobre o formalestrutural. O exemplo mais patente dessa interferência encontra-se na carta do bispo D. Pedro Fernandes ao Padre Simão Rodrigues de julho de $1552{ }^{28}$, na qual Serafim Leite responde com numerosas notas aos questionamentos que o bispo levantou sobre o procedimento do padre Manuel da Nóbrega e da Companhia, justificando tais procedimentos e apresentando negativamente a atuação de D. Pedro Fernandes.

É importante salientar que o processo editorial realizado por Serafim Leite faz parte da construção institucional de uma memória jesuítica, o que explica muitos dos critérios que adota. A interferência do compilador dá-se em diversos níveis; nos critérios de seleção da documentação, que atendem à tradição historiográfica da Companhia; na adequação da ortografia e pontuação, que pode apresentar opções duvidosas; na parcialidade dos

\footnotetext{
${ }^{27}$ LEITE, Serafim, S.J. Monumenta Brasiliae, v. I-IV. Roma, 1956-60. O quinto volume traz as cartas do Beato Inácio de Azevedo, que não estão diretamente ligadas ao nosso tema.

${ }^{28} M B I$, pp. 357-366.
} 
comentários etc. $^{29}$ A utilização historiográfica dessa compilação deve estar ancorada em uma problematização dos próprios critérios de sua organização, para evitar a reprodução acrítica da voz institucional e dos pressupostos metodológicos do Padre Serafim Leite.

Também foram consultadas cartas que não fazem parte dessa coletânea, por serem posteriores a 1568. Algumas estão em Cartas, Informações, Fragmentos Históricos e Sermões do Padre Joseph de Anchieta, S.J. $(1554-1594)^{30}$ e em publicações esparsas, como os apêndices da já citada História da Companhia de Jesus no Brasil. Foi-nos possível realizar uma consulta de poucos dias no Archivum Romanum Societatis Iesu (ARSI), por meio da qual pudemos analisar algumas cartas referentes ao nosso tema. Em caráter complementar, utilizamos documentação de outra natureza, como as atas da Câmara das vilas de Santo André da Borda do Campo e de São Paulo, relatos cronísticos como os de Fernão Cardim ${ }^{31}$, Simão de Vasconcelos ${ }^{32}$ e Gabriel Soares de Sousa ${ }^{33}$, além de alguma outra referência pontual.

Buscamos evitar o quanto possível que a análise sistemática das cartas tornasse o texto exageradamente carregado de citações longas da documentação. Dessa forma, o caráter fragmentário de muitas das referências documentais não são reflexo da nossa metodologia de leitura, mas uma tentativa de melhorar a clareza expositiva da pesquisa. Ainda assim, a necessidade de explicitar o contexto narrativo dos trechos analisados torna imperativo, em alguns momentos, a reprodução de trechos mais longos das cartas. Mesmo que esse procedimento prejudique um pouco a fluidez do texto, garante uma melhor exposição de nosso procedimento metodológico. Mantivemos a grafia original das citações tanto no que tange aos documentos quanto à bibliografia publicada anteriormente ao acordo ortográfico de 2009.

\footnotetext{
${ }^{29}$ Adriana Gabriel Cerello faz uma boa síntese das questões que envolvem a edição das cartas jesuíticas pelo Padre Serafim Leite no primeiro capítulo da dissertação O livro nos textos jesuíticos do século XVI: edição, produção e circulação de livros nas cartas dos jesuítas na América Portuguesa (1549-1563). 2007.143 f. Dissertação (Mestrado em Literatura Brasileira) - Faculdade de Filosofia, Letras e Ciências Humanas, Universidade de São Paulo, São Paulo, 2007, pp.15-30.

30 ANCHIETA, José de, S. J. Cartas, Informações, Fragmentos Históricos e Sermões do Padre Joseph de Anchieta, S .J. (1554-1594). Rio de Janeiro: Civilização Brasileira, 1933.

${ }^{31}$ CARDIM, Fernão. Tratados da terra e gente do Brasil. Introduções e notas de Baptista Caetano, Capistrano de Abreu e Rodolpho Garcia. Rio de Janeiro: J. Leite \& Cia., 1925.

${ }^{32}$ VASCONCELOS, Simão de. Chronica da Companhia de Jesu do Estado do Brasil, vol. I. $2^{\text {a }}$ ed. Lisboa: 1865 [1663].

${ }^{33}$ SOUSA, Gabriel Soares de. Tratado descriptivo do Brasil em 1587. Introdução e comentários de Francisco Adolpho de Varnhagen. Rio de Janeiro: Typographia de João Ignacio da Silva, 1879.
} 
CAPÍTULO 1

COLONOS, JESUÍTAS E ATIVIDADE EPISTOLOGRÁFICA 


\subsection{Escrita e circulação das cartas jesuíticas}

Desde a chegada do primeiro grupo de jesuítas ao Brasil, em 1549, na armada do governador-geral Tomé de Sousa, a comunicação epistolar cumpriu um papel fundamental nas atividades da Companhia de Jesus aqui desenvolvidas. Poucos dias após chegar à Bahia, o padre Manuel da Nóbrega, superior da nova Missão ${ }^{34}$, já escrevia ao provincial de Portugal, Simão Rodrigues, dando conta da chegada e do que se havia realizado até então ${ }^{35}$. A partir daí, a troca de cartas com Portugal e Roma seria constante, ainda que submetida a contingências como a frequência de embarcações.

A mais evidente função dessa correspondência era de ordem administrativa. Por intermédio das cartas, os irmãos e padres relatavam aos superiores a situação de determinada região, os trabalhos realizados, as dificuldades enfrentadas e solicitavam auxílio. Os superiores em Portugal e Roma, por sua vez, orientavam os missionários, assegurando que se cumprissem as diretrizes da ordem nos trabalhos de evangelização do gentio e ajuda aos portugueses $^{36}$. Esse caráter administrativo da epistolografia jesuítica levou muitos historiadores a atribuir-lhe uma objetividade tal que lhes permitisse recompor factualmente a história da Companhia de Jesus no Brasil ${ }^{37}$. Dessa forma, outros aspectos formais e teológicopolíticos desses textos, de que trataremos adiante, acabaram pouco considerados pelos pesquisadores até recentemente.

A grande distância e as dificuldades de comunicação - não apenas entre Europa e América, mas também entre as diversas capitanias brasileiras - reservaram às cartas um papel central na organização do trabalho missionário dos jesuítas no Brasil ${ }^{38}$. A importância da comunicação epistolar esteve presente na Companhia de Jesus desde os seus primeiros anos de existência, com vistas à manutenção da unidade de uma ordem que crescia e se expandia rapidamente. Havia outros procedimentos com o mesmo fim, como o envio de padres

\footnotetext{
${ }^{34}$ Vieram com Nóbrega os padres Leonardo Nunes, Juan de Azpilcueta Navarro, Antônio Pires e os irmãos Vicente Rodrigues e Diogo Jácome (MB I, Introdução geral, p. 7).

${ }^{35} M B I$, p. $108-15$.

${ }^{36}$ Essa função mais evidente da comunicação epistolar vem expressa nas Constituições da Companhia de Jesus, no parágrafo 629: "[...] [o superior] por meio de um frequente contato epistolar e mediante informações, tanto quanto possível, sobre o que acontece, do lugar onde reside, não deixará faltar, na medida em que as pessoas e os afazeres demandem, o seu conselho e outras possíveis ajudas" (LOYOLA, Inácio de. Gli scritti, A cura dei gesuiti della Provincia d'Italia. Roma: Edizioni Adp, 2007, p. 840, tradução nossa).

${ }^{37} \mathrm{O}$ mais emblemático nessa tendência é o próprio Serafim Leite, com a monumental História da Companhia de Jesus no Brasil, 10 vols. Lisboa: Livraria Portugália; Rio de Janeiro: Civilização Brasileira, 1938-1950.

${ }^{38}$ Cristina Pompa afirma que "a atividade epistolar dos jesuítas foi a verdadeira chave de todo seu sistema missionário" (Religião como tradução: missionários, Tupi e "Tapuia” no Brasil colonial. Bauru: EDUSC, 2003, p. 81).
} 
visitadores. No entanto, as visitações, ainda que algumas vezes bastante prolongadas, não seriam suficientes por si só para garantir o cumprimento das diretrizes provenientes da administração central da ordem, sediada em Roma. Até o final do século XVI, apenas duas visitações seriam realizadas no Brasil, a primeira pelo Padre Inácio de Azevedo, entre 1566 e 1568, e a segunda pelo Padre Cristóvão de Gouveia, entre 1583 e 1590.

A comunicação epistolar, devido à importância que lhe atribuía Inácio de Loyola, à centralidade que adquiriu com o crescimento da ordem e ao seu papel na organização das missões, foi minuciosamente regulamentada, com o objetivo de torná-la eficiente no cumprimento das diversas funções que dela se esperava. As orientações para a escrita de cartas, presentes nas Constituições da Companhia de Jesus, incorporam a experiência prática da atividade epistolar que já vinha sendo desenvolvida na ordem anteriormente. Em alguns momentos, a própria correspondência foi utilizada para a transmissão dessas diretrizes ${ }^{39}$.

As Constituições ${ }^{40}$, aprovadas pela primeira Congregação Geral da ordem em 1558, mas já presentes no Brasil desde 1556, apresentavam orientações bastante específicas sobre o desenvolvimento dessa atividade. Tais orientações seguiam o teor geral do documento, que não regulamentava as atividades da Companhia de maneira inflexível, deixando bastante espaço à prudência, ao discernimento espiritual e à obediência hierárquica. Em relação a essa interpretação das diretrizes do documento, temos como exemplo o que escreve o Padre Luís da Grã, em carta de 1556, enviada da casa de Piratininga a Inácio de Loyola. Grã dá notícia do recebimento das Constituições e afirma que trabalhará "con la gracia divina de hazer con que nos acomodemos quanto más possible fuere por la diversidad de tierra" ${ }^{41}$.

O texto das Constituições, fruto de um longo processo de escrita e diversas revisões, sob os cuidados de Loyola e do secretário Juan Alfonso de Polanco, apresenta um caráter de síntese da experiência prática da Companhia até então, incorporando e sistematizando documentações produzidas anteriormente e a própria maneira de proceder desenvolvida em sua atividade ministerial desde a união dos primeiros companheiros ${ }^{42}$. A comunicação

\footnotetext{
${ }^{39}$ Para o caso dos missionários brasileiros, conferir, por exemplo, a carta de Inácio de Loyola de 18 de julho de 1553 (MB I, pp. 512-3) e a do secretário Polanco de agosto do mesmo ano, de que trataremos adiante (MB I, pp. 519-20).

${ }^{40}$ Utilizamos aqui o sentido amplo de Constituições, que inclui também o Exame Geral e as Declarações sobre as Constituições e Exame Geral. Esta versão mais ampla foi impressa pela primeira vez em 1570, sob o generalato de Francisco de Borja. Na versão aprovada pela primeira Congregação Geral em 1558, estavam reunidos somente as Constituições e o Exame Geral, sendo as correspondentes Declarações impressas à parte.

${ }^{41} M B$ II, p. 288.

${ }^{42}$ Sobre a História da escrita, revisões e diferentes versões e publicações das Constituições, conferir a detalhada introdução de Maurizio Costa S. I. ao texto, In: LOYOLA, Inácio de. Gli scritti, A cura dei gesuiti della Provincia d'Italia. Roma: Edizioni Adp, 2007, pp. 541-601.
} 
epistolar é tratada mais detidamente na Parte Oitava ${ }^{43}$, que se ocupa da união dos membros da Companhia; união que não se limita a um aspecto administrativo ou prático, mas que se refere também ao aspecto consolador, no sentido espiritual, da "união dos ânimos". Esse caráter consolador da epistolografia é fundamental para compreender sua circulação e leitura dentro e fora da Companhia. O texto determina detalhadamente a frequência com que as cartas devem ser escritas, ainda que segundo as circunstâncias, propondo a comunicação mensal com os superiores para quem está em localidades distantes e estabelecendo a carta quadrimestral, contendo somente as notícias edificantes e escrita na língua falada na região, acompanhada de outra do mesmo teor em latim $^{44}$.

A epistolografia jesuítica configurou-se como um gênero misto, variando em seu aspecto formal de acordo com a matéria tratada e a maior ou menor abertura da carta para fora da Companhia. Nesse sentido, podemos identificar, até o final do século XVI, dois tipos principais de $\operatorname{cartas}^{45}$ : as edificantes/noticiosas e as hijuelas ${ }^{46}$. Estas últimas tratavam de assuntos administrativos da Companhia e não deveriam circular fora da ordem. A hijuela foi instituída pelo próprio Inácio de Loyola em 1541, com o objetivo de separar da carta principal, que deveria ter um teor edificante, os assuntos referentes à vida interna da Companhia. A necessidade de escrever separadamente sobre temas de edificação e demais assuntos vem expressa em 1553 por Inácio, em uma carta a Manuel da Nóbrega, nos seguintes termos:

[...] V.R. tenga forma de scrivir y hazer que los suyos scrivan a Roma (ultra de lo que querrán scrivir a Portugal), no solamente de cosas de edificación, pero lo demás también, que conviene que sepa el Prepósito General; y las letras de edificación no contengan otros negocios. Vengan de por $\mathrm{si}^{47}$.

A carta é ela mesma um claro exemplo de hijuela, bastante sucinta e direta, trata pontualmente de questões práticas, orientando a atuação de Nóbrega. No trecho citado, as diretrizes que Inácio transmite para a escrita de cartas fornecem-nos especularmente a avaliação que o prepósito-geral fazia da prática epistolar dos missionários do Brasil até aquele

\footnotetext{
${ }^{43}$ LOYOLA, Inácio de. Gli scritti, A cura dei gesuiti della Provincia d'Italia. Roma: Edizioni Adp, 2007, pp. 855-7. A própria estrutura do documento, dividido por situações a serem enfrentadas e não por temas, leva a um tratamento fragmentado dessa atividade; assim, o benefício espiritual da leitura das cartas edificantes é abordado na Parte Terceira, sobre os progressos dos que estão na fase de Provação; o aspecto administrativo é citado rapidamente na Parte Sétima, sobre as relações no interior da ordem, e assim por diante.

${ }^{44}$ LOYOLA, op. cit., p. 856.

${ }^{45}$ Havia também as listas, com nomes e informações sobre os padres e irmãos, bem como sobre colégios e residências. São regulamentadas no parágrafo 676 das Constituições (ibid., p. 857).

${ }^{46}$ POMPA, Cristina. Religião como tradução: missionários, Tupi e "Tapuia" no Brasil colonial. Bauru: EDUSC, 2003, p. 82. Segundo a autora, essa divisão iria tornar-se menos rígida no século XVII.

${ }^{47} M B I$, p.513.
} 
momento. A indicação para que se escrevesse "no solamente de cosas de edificación" é uma clara referência ao predomínio desse tipo de texto e à carência de informações mais concretas sobre a atividade dos missionários, o que também explica a orientação de se escrever diretamente a Roma, além do que se escrevesse a Portugal. A necessidade de se indicar que as cartas de edificação não contenham "otros negocios" mostra que, no entender de Loyola, a correspondência não estava até então seguindo essa divisão na medida desejada.

A separação entre cartas edificantes e hijuelas relacionava-se à maneira como os jesuítas - Inácio de Loyola em particular - incorporaram as tradições epistolográficas medieval e renascentista. $\mathrm{O}$ aspecto formal da epistolografia jesuítica liga-se intimamente à tradição da ars dictaminis, que, apesar das contribuições anteriores, notadamente da retórica clássica, configurava-se como uma invenção medieval, sistematizada no século $\mathrm{XI}^{48}$. Os dictatores consolidaram a epistolografia como um campo de estudos específico ${ }^{49}$, com o qual irão dialogar as posteriores propostas humanistas, erasmianas e inacianas de escrita epistolográfica $^{50}$. A proposta humanista retomará a tradição clássica, que entendia a carta como espaço para a conversação informal, acabando por acentuar a "oposição entre a carta formal (contentio) pensada pelo dictator medieval e a carta familiar (sermo) ${ }^{, 51}$. O modelo inaciano aproxima-se mais daquele formulado por Erasmo, que propõe uma adequação flexível do gênero à matéria tratada ${ }^{52}$. Na proposta jesuítica, os dois tipos principais de cartas seguiam a oposição sermo/contentio. As cartas que tratam de assuntos internos à ordem hijuelas - seriam mais objetivas, amigáveis e, portanto, ligadas ao modelo da correspondência clássica. As cartas edificantes/noticiosas circulariam também no exterior da Companhia e atenderiam a objetivos mais amplos, adequando-se ao modelo sistemático da $\operatorname{ars~dictaminis~}^{53}$.

Ainda que houvesse orientações bastante específicas para os diferentes tipos de carta, nem sempre a distinção é simples de ser feita, como destaca Cristina Pompa ${ }^{54}$. As cartas ditas edificantes cumprem também o papel de informar a administração central da ordem a respeito dos sucessos do trabalho missionário, mesmo que organize essas informações

\footnotetext{
48 MURPHY, James J. La retorica nel Medioevo: Una storia delle teorie retoriche da s. Agostino al Rinascimento. Napoli: Liguore Editore, 1983, p. 223.

${ }^{49}$ Ibid., pp. 223-33.

${ }^{50}$ PÉCORA, Alcir. "Arte das Cartas jesuíticas do Brasil”. In: ENCONTRO INTERNACIONAL NÓBREGAANCHIETA, 1999, São Paulo. VOZ LUSÍADA. Anais do Encontro Internacional Nóbrega-Anchieta. São Paulo: Green Forest do Brasil, 1999, v. 1, p. 32-43.

${ }^{51}$ Ibid., p. 36.

52 Ibid., p. 38.

${ }^{53}$ EISENBERG, José. As missões jesuíticas e o pensamento político moderno: Encontros culturais, aventuras teóricas. Belo Horizonte: Ed. UFMG, 2000, p. 53-58.

54 POMPA, Cristina. Religião como tradução: missionários, Tupi e "Tapuia" no Brasil colonial. Bauru, SP: EDUSC, 2003, p. 83.
} 
priorizando o aspecto edificante ou a descrição das populações nativas. A adequação ao gênero, por sua vez, no que diz respeito ao conteúdo e ao estilo, não é uniforme para todo o século XVI, nem para todos os missivistas. As diretrizes para a escrita das cartas edificantes tornam-se mais específicas a partir da experiência dos primeiros anos, e mudam de acordo com as necessidades apontadas pelas lideranças romanas da Companhia, como apontamos anteriormente com as orientações de Loyola para Nóbrega. No decorrer da segunda metade século XVI, o aspecto edificante vai progressivamente cedendo espaço ao informativo, mesmo nas cartas edificantes/noticiosas ${ }^{55}$.

Em carta de 1553, o padre Juan de Polanco, por comissão de Inácio de Loyola, escreve a Nóbrega dando orientações para a comunicação epistolar. A carta é curta, em linguagem bastante objetiva e clara, como deveriam ser as hijuelas ${ }^{56}$. Nela predomina o tom prescritivo, pelo qual se evidencia a relação hierárquica entre os interlocutores. Polanco justifica as diretrizes apresentadas por ter, até o momento, "informaciones muy imperfectas de las cosas de allá [Brasil]",57. Para as cartas "mostrables" (edificantes/noticiosas), as informações desejadas são bastante específicas:

[...] se dirá en quántas partes ay residentia de los de la Compañía, quántos ay en cada una, y en qué entienden, tocando lo que haze a edificatión; asimesmo cómo andan vestidos, de qué es su comer y beber, y las camas en que duermen, y qué costa haze cada uno dellos. También, quanto a la región dónde está, en qué clima, a quántos grados, qué vezindad tiene la tierra, cómo andan vestidos, qué cómen, etc.; qué casas tienen, y quántas, según se dize, y que costumbres; quántos christianos puede aver, quántos gentiles o moros; y finalmente, como a otros por curiosidad se scriven muy particulares informaciones, asi se scrivan a nuestro Padre, porque mejor sepa cómo se ha de proveer $[\ldots]^{58}$.

Podemos visualizar na carta quadrimestral escrita pelo ainda irmão José de Anchieta em 1554, referente ao período entre maio e agosto daquele ano ${ }^{59}$, uma adequação rigorosa a esse formato, fornecendo pontualmente as informações apontadas como desejadas. As quadrimestrais subsequentes, dele e do também irmão Antônio Blasquez, apresentam já alguma flexibilização, dado que buscavam apenas atualizar o quanto se enviara

\footnotetext{
55 Fernando Torres-Londoño destaca a insistência maior de Inácio de Loyola no aspecto edificante da correspondência durante a década de 1540 , enquanto na década seguinte a insistência seria em seu aspecto informativo. Esta mudança de ênfase reflete também uma já boa assimilação do modelo edificante por parte dos missionários ("Escrevendo Cartas. Jesuítas, Escrita e Missão no Século XVI", Revista Brasileira de História. São Paulo, v. 22, nº 43, 2002, pp. 11-32).

${ }^{56} M B I$, pp. 519-20.

${ }^{57} M B I$, p. 519.

${ }^{58} M B$ I, p. 520.

${ }^{59}$ MB II, pp. 83-118.
} 
anteriormente ${ }^{60}$. Justamente por responderem ao que se considerou em Roma uma deficiência nas cartas anteriores, diferenciam-se das edificantes precedentes tanto no conteúdo quanto na maneira de organizá-los. Dessa forma, não é possível considerar as cartas edificantes/noticiosas como um formato único e constante. As primeiras quadrimestrais escritas por Anchieta são indicativas do momento de mais clara diferenciação entre as cartas edificantes e hijuelas, que se verifica inclusive na divisão do encargo de sua produção. $\mathrm{O}$ Padre Luís da Grã, também de Piratininga, escreve a Inácio de Loyola, em junho de 1556, acerca de diversos problemas de ordem prática, tratando "solamente destas cosas que avían menester consultadas, y las otras de edificación y nuevas de acá escrevirá el Hermano Joseph, a quien el Provincial, tiene dado esse cargo" ${ }^{\circ 1}$. Ainda que busquemos, em nossa pesquisa, identificar suas características específicas, é necessário considerar como cada carta relacionase com as determinações da epistolografia jesuítica, visto que não se trata de uma normatização estanque.

Considerando-a de maneira geral, a técnica epistolográfica jesuítica para as cartas edificantes utiliza, com alguma flexibilidade, a tradicional divisão em cinco partes, própria da ars dictaminis medieval: salutatio, benevolentiae captatio, narratio, petitio e conclusio ${ }^{62}$. As cinco partes não aparecem sempre como uma divisão física do texto; a petitio e a benevolentiae captatio estão frequentemente diluídas ao longo da narratio ou daquilo que outras propostas de divisão classificam de exordium, que inclui, além da benevolentiae captatio, algumas informações sobre a escrita da carta e resumo do que se escreveu antes.

A salutatio, parte mais discutida pelos teóricos medievais da ars dictaminis, assume, na maioria das cartas da Companhia de Jesus, fórmulas que reforçam a união entre os membros, como as variações do tema básico "A graça/paz/amor de Cristo seja sempre em nosso favor e ajuda/em nossas almas", podendo assumir até mesmo a forma resumida "A paz e amor de Cristo etc". Pode ou não ser precedia de uma reverência, como o respeitoso e frequente "Muy Reverendo em Christo Padre". O destaque à hierarquia é mais frequente nas cartas dirigidas a autoridades exteriores à Companhia, como aparece em carta de Nóbrega ao

\footnotetext{
${ }^{60}$ Cf., por exemplo, $M B$ II, cartas 32, 43, 48 (trimestral), 52 e 65.

${ }^{61}$ MB II, pp. 295-6.

${ }^{62}$ A divisão em cinco partes não é a única utilizada pelos dictatores medievais, mas, segundo James J. Murphy, é o modelo que se cristaliza como padrão no século XII e com o qual as outras propostas dialogam (La retorica nel Medioevo: Una storia delle teorie retoriche da s. Agostino al Rinascimento. Napoli: Liguore Editore, 1983, p. 257). João A. Hansen propõe uma divisão na qual petitio e conclusio não aparecem como categorias destacadas: “[...] a carta jesuítica apropria-se dos esquemas gerais da técnica epistolar da ars dictaminis, apresentando as três ou quatro partes definidas nas doutrinas antigas e medievais da mesma - salutatio, exordium (captatio), narratio (argumentatio), subscriptio" ("O nu e a Luz: Cartas jesuíticas do Brasil. Nóbrega, 1549-1558”, Revista do Instituto de Estudos Brasileiros, São Paulo, n. 38, 1995, p 88).
} 
governador-geral Tomé de Sousa, com a salutatio "A pax e amor de Christo N. Senhor seja sempre em seu continuo favor e ajuda. Amen" ${ }^{\prime 63}$.

A benevolentiae captatio, que visa a alcançar a boa disposição do leitor, aparece nas cartas da Companhia por meio de fórmulas de humildade, desejo de martírio e obediência. Frequentemente repete-se ao longo da narratio, mas é comum concentrar-se no exordium, que funciona como uma preparação para a narratio. A utilização desse recurso, assim como das outras divisões, não é rígida, o que torna possível encontrar diferenças em sua aplicação por parte dos missivistas. A carta edificante que o Padre Juan de Azpilcueta Navarro escreve em Porto Seguro, a 19 de setembro de 1553, apresenta um exemplo limite de utilização quase que desmesurada desse recurso:

Quando mi flaco entendimiento se pone a pensar en vos, Charíssimos, recibe tanto esfuerço y tanta consolación, quanta Dios sabe, y si aún tiene alguna virtud o fortalesa, es con vuessa memoria que el Señor sustenta en las aguas y peligros spirituales y corporales destas partes, donde andamos dispargidos in eodem spiritu devaxo de la bandera de la santa obediciencia sembrando la palabra de Christo Jesú nuestro Maestro, la qual en partes vay en acrecentamiento, puesto que yo soy por mis peccados el que menos trabaja y por quien el Señor menos obra, por mi poca abelidad [...] O Charíssimos, quán differente es hablar de las virtudes y tenerlas, y platicar del martirio y ponerla por obra! [...] Si mi ánima fuera clara y limpia, charíssimos Hermanos, las lágrimas hallara por consolación, los trabajos dulces por Jesú Christo, empero a este cuerpo malo y sensualidad lo bueno le parece malo, lo dulce amargoso. Suppla pues el bendito Jesú mis flaquezas por su bondad y misericordia y déme gracia en su Compañia ${ }^{64}$.

A citação é longa, mas sua reprodução permite visualizar não somente alguns dos elementos mais comuns da benevolentiae captatio nas cartas jesuíticas, como também a grande importância que lhe era atribuída. Na carta em questão, essa benevolentiae captatio inicial ocupa quase um quarto do espaço, além de haver algumas outras utilizações mais discretas ao longo da narratio. No geral, a utilização era bastante mais contida e curta, mas seguia esse mesmo direcionamento.

A narratio, nas cartas jesuíticas, trata principalmente dos temas da evangelização do gentio; da condenação dos maus hábitos dos colonos, dentre os quais o cativeiro injusto de indígenas cumpre papel central; da fundação de casas e colégios, bem como de outras medidas administrativas da Companhia; da atividade ministerial com índios e colonos; e das características da terra e das populações nativas. João Adolfo Hansen, tratando especificamente das cartas de Manuel da Nóbrega, identifica "pelo menos 4 grandes recortes

\footnotetext{
${ }^{63} \mathrm{MB} I I I$, p. 70, grifo nosso.

${ }^{64} \mathrm{MB} I I$, pp. $4-5$.
} 
temáticos": o do índio, o do colono e da depravação de seus costumes, o das medidas administrativas e militares de governadores e o do clero secular ${ }^{65}$. Dados os aspectos referentes à comunicação epistolar que discutimos até aqui, fica claro que a narratio não se configura como um simples relato dos avanços da Missão. De fato, mesmo restringindo-se a essa documentação, o cotejamento entre cartas de diferentes períodos mostra que os relatos edificantes não retratavam o real avanço na evangelização do gentio, notadamente nas duas primeiras décadas ${ }^{66}$, nas quais, além do predomínio do modelo edificante, havia um otimismo um tanto exagerado quanto à disposição do gentio para a fé. A descrição do trabalho missionário com os indígenas, bem como dos demais temas, era organizada na narratio de acordo com as diversas funções que as cartas cumpriam, como a consolação e união dos membros da ordem, a construção de uma imagem da Companhia (internamente e externamente), a divulgação dos resultados da missão, a devoção religiosa e, até mesmo, a de suprir uma demanda leiga por informações relativas às populações americanas.

É importante destacar ainda que a narração da atividade missionária não era feita apenas em relação aos resultados com o gentio, mas também se procurava apresentar o cumprimento por parte do missionário do Instituto da Companhia, que tinha na atividade ministerial sua própria identidade. Em relação a esse ponto, uma carta do visitador Cristóvão de Gouveia, enviada da Bahia em 19 de agosto de 1585, constitui notável exemplo, ainda mais interessante por não se tratar de uma carta mostrable, já que discorre objetivamente sobre assuntos internos à ordem. Em trecho no qual relata a situação dos padres e irmãos na capitania do Espírito Santo, destaca o impecável cumprimento do ministério pelo padre Manuel de Paiva:

todos los padres y hermanos tenian salud, excepto el P. Manoel de Paiva que por ser de 80 annos y tener mas de treinta de la conp ${ }^{a}$ siendo delos primeros que uenieron a esta prouincia, y en ella auia trabajado, predicando, confessando, y ensennando alos indios, y portugueses con gran fruito y edificacion, lleuole nuestro snor $\sim$ para si a 23 de deziembre de 83 fue su muerte muy sentida de todos los de aquella uilla por ser muy amado de $\operatorname{todos}^{67}$.

Explicitar os critérios de organização dos temas na narratio não significa considerar falsas as informações ali presentes. Seria anacrônico interpretar as cartas jesuíticas a partir de modalidades de escrita alheias a esse contexto histórico. As categorias teológico-políticas e a

\footnotetext{
${ }^{65}$ HANSEN, João Adolfo. "O nu e a Luz: Cartas jesuíticas do Brasil. Nóbrega, 1549-1558”, Revista do Instituto de Estudos Brasileiros, São Paulo, n. 38, 1995, p. 91.

${ }^{66}$ TORRES-LONDOÑO, Fernando. "Escrevendo Cartas. Jesuítas, Escrita e Missão no Século XVI", Revista Brasileira de História. São Paulo, v. 22, n 43, 2002, p. 26.

${ }^{67}$ ARSI, Lus. 69, f. 133.
} 
disposição formal que organizam os relatos não estão ligadas apenas à operação de escrita, mas à própria interpretação dessa realidade e à maneira de nela atuar. A veracidade de um episódio narrado não é dada pela objetividade de um relato factual, mas pela sua capacidade em exprimir um estado geral das coisas, interpretado a partir de categorias compartilhadas pelo círculo mais amplo em que as cartas circulam. Dessa forma, é comum os temas serem dispostos na narratio como uma sequência de cenas exemplares, capazes de transmitir à pessoa ausente esse estado geral das coisas. Isso se dá de formas variadas e dependendo da maior ou menor especificidade do tema tratado.

Insistimos, contudo, que esse procedimento analítico não visa a reduzir a possibilidade documental da correspondência jesuítica à subjetividade do discurso da ordem, mas pressupõe a problematização da estrutura retórica e formal do texto na análise da realidade colonial, como discutimos em nossa introdução. Assim como Cristina Pompa, consideramos que "a idéia não é a de extrair o quanto de 'verdadeiro' nelas [cartas jesuíticas] existe, e distingui-lo do "retoricamente construído",68, mas a de lidar com as informações no interior da prática discursiva que as compreende.

Nesse mesmo sentido, não é possível separar claramente, nas cartas edificantes/noticiosas, o aspecto propriamente edificante do informativo (no sentido de um relatório das atividades e das questões com que se devia lidar). Ainda que entre esta modalidade de carta e a hijuela houvesse diferenças na maneira de selecionar e apresentar os assuntos, ambas cumpriam a função de informar os interlocutores europeus da situação dos membros e do estado da terra. Da mesma forma, não é possível afirmar que o aspecto edificante estivesse de todo ausente nas hijuelas, mesmo com sua objetividade e circulação mais restrita. A consciência dessa dupla função da correspondência aparece nas próprias cartas, como podemos detectar em uma escrita pelo Padre Diego Mirón em Lisboa, no ano de 1554 e destinada ao prepósito-geral Inácio de Loyola. Nela, Mirón afirma que o cardeal D. Henrique informa-se sobre a situação da Companhia no Brasil e Índia através das cartas, para poder "ayudar e prover acerca dello todo lo que fuesse menester". Indicava-lhe a leitura o próprio padre Mirón, por lhe "parecer que se edificaría e alegraría mucho in Domino"69. Considerando o contexto mais amplo do trecho, percebemos que "edificar", nesse caso, além de se referir ao proveito espiritual do cardeal, era também uma maneira sutil de dizer que o tornaria mais bem disposto a favorecer o trabalho missionário da Companhia.

\footnotetext{
${ }^{68}$ POMPA, Cristina. Religião como tradução: missionários, Tupi e "Tapuia” no Brasil colonial. Bauru: EDUSC, 2003 , p. 81.

${ }^{69}$ MB II, pp. 24-5.
} 
A petitio presente nas cartas jesuíticas do Brasil diz respeito, na maioria das vezes, à necessidade do envio de mais padres, a pedidos mais pontuais, como o envio de livros, adornos para as Igrejas e dispensas papais, e ao recorrente pedido de orações. Frequentemente vem localizado ao longo da narratio, no espaço dedicado ao assunto correspondente. Pode também ser retomado ou reforçado na conclusio, que, algumas vezes, reapresenta sumariamente o conteúdo ou os argumentos da carta. Em algumas, no entanto, o encerramento é mais brusco, passando-se da narratio para uma saudação final.

O caminho mais comum dessas cartas era seguir primeiramente para Portugal, e somente depois para $\operatorname{Roma}^{70}$, o que tornava a comunicação e a tomada de medidas administrativas relativamente lentas. Em relação às questões práticas, muito se provinha já em Portugal, em um primeiro momento, o que levou à instrução já citada de que se escrevesse também a Roma ${ }^{71}$. As cartas eram copiadas e traduzidas, sendo depois enviadas às casas e colégios da Companhia, em cópias impressas e manuscritas, para servirem de leitura edificante e consoladora, além de instrução para os noviços ${ }^{72}$. Para o nosso período, esse processo de circulação foi bastante marcado pela atuação do secretário Juan Alfonso de Polanco, que corrigia, censurava e emendava as cartas antes de sua difusão. A grande flexibilidade com que se resumia, juntava ou cortava partes das cartas é bastante reveladora do contexto de leitura no interior da Companhia. O próprio Serafim Leite, em seu trabalho editorial, identifica diversas alterações e distorções referentes a datas, destinatários, locais de origem etc., o que o leva a recomendar cuidado ao se utilizar as versões emendadas por Polanco $^{73}$. Isso, que para nós parece uma menor atenção aos pormenores factuais das narrativas edificantes, indica um maior interesse em outro aspecto dos relatos, seu papel mais amplo de "reiteração do código" 74 doutrinário, o que está em acordo com a maneira com que os missivistas dispunham os temas na narratio. Não significa, contudo, que a leitura das cartas como narrativa factual estivesse ausente. De fato, as cartas foram utilizadas frequentemente na composição de crônicas mais amplas sobre a presença jesuítica nas

\footnotetext{
70 PROSPERI, Adriano. "As missões no Brasil, vistas de Roma”. Comunicação apresentada no Colóquio internacional Contextos missionários: Religião e poder no Império português, realizado na Universidade de São Paulo, 1-5 de outubro de 2007, p. 3.

${ }^{71} M B I$, p.513.

${ }^{72} M B$ I, Introdução geral, pp. 53-6.

${ }^{73} M B I$, Introdução geral, p. 59.

${ }^{74}$ Utilizamos aqui a expressão de João Adolfo Hansen (“O nu e a Luz: Cartas jesuíticas do Brasil. Nóbrega, 1549-1558”, Revista do Instituto de Estudos Brasileiros, São Paulo, n. 38, 1995, p. 94).
} 
diversas províncias, das quais o exemplo mais emblemático é o Chronicon Societatis Jesu do mesmo Juan Alfonso de Polanco ${ }^{75}$.

A publicação de compilações das cartas jesuíticas não estava voltada apenas à própria Companhia. Durante o século XVI, diversas compilações desta correspondência foram publicadas em diferentes línguas ${ }^{76}$. Ao serem compiladas e publicadas em forma de livro, as cartas são "inseridas em novo meio material de circulação e em novos contextos de leitura que lhes modificam a função”, perdendo o aspecto prático que baseava sua escrita, como apontado por João Adolfo Hansen ${ }^{77}$. As compilações circulavam também nos ambientes externos à Companhia, funcionando como texto apologético ou respondendo à demanda leiga por informações sobre as populações do Novo Mundo ${ }^{78}$. Desta forma, o aspecto edificante que orientava a escrita das cartas assim nomeadas assume um caráter devocional mais amplo, adequado ao novo contexto de circulação. Esse novo meio de circulação representava também, para a Companhia de Jesus, um espaço para construir uma autoimagem para fora da ordem. Nas palavras de Adriano Prosperi:

[...] de facto, o que tinha sido impresso não era o texto real das cartas enviadas pelos missionários, mas o fruto de um trabalho editorial complexo, feito de selecção e de censura, destinado a fornecer uma determinada imagem e a controlar rigorosamente as reacções dos leitores. Em suma, um trabalho destinado à propaganda ${ }^{79}$.

A partir das diversas problemáticas sinteticamente apresentadas, evidencia-se como os missionários jesuítas escreviam suas cartas em uma situação institucionalmente condicionada $^{80}$, à qual somente de maneira anacrônica pode-se atribuir o conceito de escrita autoral, tal como a entendemos hoje. Além do fato, já destacado, de que as cartas eram livremente cortadas e emendadas pelos superiores antes de serem inseridas em seu meio de circulação, a atividade epistolográfica era regida por determinações formais e materiais, por

\footnotetext{
75 O’MALLEY, John W. Os primeiros jesuítas. Tradução Domingos Armando Donida. São Leopoldo, RS: Editora UNISINOS; Bauru, SP: EDUSC, 2004, pp. 29-30.

${ }^{76}$ Serafim Leite apresenta uma relação das edições das primeiras cartas do Brasil. Para o século XVI, indica traduções em castelhano, italiano e latim, publicadas em Coimbra, Roma e Veneza (MB I, Introdução geral, pp. 69-73).

${ }^{77}$ HANSEN, João Adolfo. “O nu e a Luz: Cartas jesuíticas do Brasil. Nóbrega, 1549-1558”, Revista do Instituto de Estudos Brasileiros, São Paulo, n. 38, 1995, pp. 90-1.

${ }^{78}$ Em relação à importância do gênero da carta para a época e seu aspecto "literário", cf. AGNOLIN, Adone. Jesuítas e Selvagens: A negociação da fé no encontro catequético-ritual americano-tupi (séc. XVI - XVII). São Paulo: Humanitas Editorial, 2007, pp. 454-8.

79 PROSPERI, Adriano. “O missionário”. In: VILLARI, Rosario (dir.). O homem barroco. Lisboa: Presença, 1995, p. 148.

${ }^{80}$ Referimo-nos aqui à proposta analítica de João Adolfo Hansen para as letras coloniais ("Para uma história dos conceitos das letras coloniais luso-brasileiras dos séculos XVI, XVII e XVIII”. In: FERES JÚNIOR, João; JASMIN, Marcelo (orgs.). História dos conceitos: diálogos transatlânticos. Rio de Janeiro: Editora PUC-Rio/ Edições Loyola/ IUPERJ, 2007, pp. 253-266).
} 
códigos retóricos e teológico-políticos, bem como por uma seleção de temas influenciada pelas expectativas de seu meio de circulação. A escrita, portanto, desenvolve-se pela adequação aos parâmetros institucionais da Companhia de Jesus. Este processo pode ser visualizado até nas próprias cartas, como podemos constatar em uma que o irmão Antônio Blasquez escreve da Bahia, em janeiro de 1557:

Em a outra contey o que o Senhor se dignou de obrar antes da vinda de nosso Padre, e creo que confusamente e não com tanta ordem como convinha, porque não estava ainda destro em esta maneira de escrever; agora com a enformação que do Padre tenho tomado proseguirey com mais clareza que até qui ${ }^{81}$.

O eixo temático da correspondência jesuítica do Brasil não é um reflexo dos elementos presentes nas atividades cotidianas dos missionários. Há diversas particularidades que só podemos entrever de forma bastante indireta e outras que podemos apenas supor. $\mathrm{O}$ tema da escravidão indígena é o maior exemplo desta questão. Lembrando que a escrita de cartas não é apenas uma narração da atuação jesuítica a respeito da sujeição do indígena, mas parte fundamental desta atuação, não encontramos nestas cartas uma descrição da relação cotidiana da Companhia com a escravidão, mas uma ativa interferência com sentido prospectivo, contrária aos procedimentos adotados pelos colonos. Dessa forma, a utilização de escravos nas casas e colégios jesuíticos do Brasil aparece discretamente na correspondência, somente quando se torna necessário discuti-la internamente ou responder a questionamentos exteriores à ordem, sem que figurasse nas cartas destinadas à circulação mais ampla. Encontramos referências desse tipo, por exemplo, nas cartas em que se discute a sustentação das casas e colégios, nas quais se contrapõem os posicionamentos de Manuel da Nóbrega e Luís da Grã ${ }^{82}$.

Diversos outros aspectos do cotidiano dos missionários jesuítas podem ser visualizados somente quando referidos por algum questionamento exterior. É o caso dos Capítulos que Gabriel Soares de Sousa escreveu contra os padres da Companhia, aos quais os próprios responderam ponto a ponto ${ }^{83}$. As diversas críticas dirigidas por Soares de Sousa à Companhia de Jesus concentraram-se na condenação da atuação jesuítica em relação aos índios, a fartura econômica das casas e colégios, os conflitos por terras, o desrespeito às

\footnotetext{
${ }^{81}$ MB II, pp. 346-7.

${ }^{82}$ Cf., por exemplo, a carta que Nóbrega escreve ao padre Diego Laines em junho de 1561 (MB III, carta 52, pp. 354-67).

${ }^{83}$ SOUSA, Gabriel Soares de. "Capítulos que Gabriel Soares de Sousa deu em Madrid ao Sr. D. Cristovam de Moura contra os padres da Companhia de Jesus que residem no Brasil, com umas breves respostas dos mesmos padres que dêles foram avisados por um seu parente a quem os ele mostrou", Anais da Biblioteca Nacional, 62, 1940 [1587], pp. 347-381.
} 
autoridades monárquicas etc. Ainda que nos atenhamos às respostas dos jesuítas, a imagem de um cotidiano pobre fornecido pelas cartas acaba por ser bastante relativizado, mesmo se considerarmos aquelas em que se discute a sustentação econômica da atividade missionária. Na década de 1580 a situação econômica da ordem é bastante diferente em relação aos anos iniciais, mas não será tratada na correspondência com a clareza e os pormenores com que aparece neste texto. As cartas tampouco abordam os temas da expulsão de padres e irmãos e do uso de excomunhões com a objetividade e detalhes com que são debatidos nos Capítulos $^{84}$.

Uma situação semelhante ocorre com as respostas de Manuel da Nóbrega às críticas levantadas pelo bispo D. Pedro Fernandes. Além das questões propriamente doutrinárias, de que nos ocuparemos mais à frente, o bispo questiona, em carta para o padre Simão Rodrigues ${ }^{85}$, algumas práticas dos membros da ordem ligadas à disciplina e a mortificação, bem como atividades econômicas ${ }^{86}$. Nóbrega escreve, ao mesmo Simão Rodrigues, que de “nossas mortificações entende [o bispo] pouco o spirito dellas e reprehende-o muito" ${ }^{\text {, }}$. Que estes temas não fossem ordinariamente abordados na correspondência é fácil de compreender. Além de não corresponderem aos temas de interesse do meio de circulação das cartas, referem-se a particularidades cotidianas da vida na ordem que, juntamente com outros pormenores práticos, não teriam relevo algum para os próprios membros. $\mathrm{O}$ padre Baltasar Fernandes fornece-nos alguns dos critérios que justificam a ausência de informações: “[...] as particularidades não conto, por serem ellas comuns aos da Companhia, aonde quer que se acham, e mays pera não enfandar e por não violar ou injuriar o sygillo da confissam" Outras questões internas, como desentendimentos entre membros, relaxamento na observância do Instituto etc., podem ser visualizados apenas em algumas cartas de circulação restrita ${ }^{89}$. A clareza com que o visitador Cristóvão de Gouveia aponta as falhas de um padre de Piratininga, por exemplo, difere em muito do tom presente nas cartas edificantes:

En piratininga el $p .^{\text {e }}$ Pantelaon gtz andaua muy inquieto en la uocacion, pediome con instançia le diesse la licencia; es persona de muy poco spu', y muy aparejado para desastres, mas como no alle del cosa muy notable,

\footnotetext{
${ }^{84}$ SOUSA, Gabriel Soares de. "Capítulos que Gabriel Soares de Sousa deu em Madrid ao Sr. D. Cristovam de Moura contra os padres da Companhia de Jesus que residem no Brasil, com umas breves respostas dos mesmos padres que dêles foram avisados por um seu parente a quem os ele mostrou", Anais da Biblioteca Nacional, 62, 1940 [1587], pp. 372-3.

${ }^{85} M B I$, carta 49, pp. 357-66.

${ }^{86} M B I$, pp. 362-3.

${ }^{87} M B$ I, p. 374.

${ }^{88} M B I V$, pp. 459-60.

${ }^{89}$ Cf., por exemplo, ARSI, Lus. 69, ff. 133-4 e ff. 53-4.
} 
procure [1] e consolarle y animarle y ansi quedo, mas tengo pocas esperanças de su perseuerancia ${ }^{90}$

Havia ainda a consciência de que nem todos os assuntos deveriam ser tratados por carta ou, ao menos, não explicitamente. Assim se expressa Anchieta em carta de 1583 ao rei Felipe II, na qual apresenta informações acerca da presença da armada de Diego Flores Valdés no Brasil, mas omite algumas "que no son para carta" 91 , que depois deveriam ser apresentadas pessoalmente pelo próprio Valdés. O padre Miguel de Torres escreve a Nóbrega de Lisboa, em maio de 1559, recomendando cautela na relação com as autoridades monárquicas portuguesas. No que toca à comunicação epistolar, afirma:

Quanto más necessario es que V. R. ${ }^{a}$ nos dee los avisos y informe como haze de las cosas universales y particulares dessas partes, tanto más importa el secreto en ello, porque se viniesse a descubrirse no se podría tam bien hazer y seguirse hian muchos inconvenientes y este medio para el servicio de Dios que se pretende podrá perder su efficacia, por lo qual advierta V. R. ${ }^{a}$ de escrivir siempre por las personas más fiadas que hallare. Acerca del modo nos parecía que devría narrar el facto y las ponderaciones moderadas con palabras escogidas, escusando quanto sea possible la intención agena [...] y quando este modo no bastase para declarar lo necesario y importante de la cosa, sería bueno escrivir en latín o en cifra lo que podía offenser si se viesse de alguno ${ }^{92}$.

Para o assunto de nossa pesquisa, a consideração desses critérios de seleção dos temas é fundamental, já que uma parte considerável das atividades cotidianas dos jesuítas com os portugueses inserem-se justamente no conjunto de temas que ordinariamente não são abordados pelas cartas, ou o são de forma apenas marginal ${ }^{93}$, como veremos no tópico a seguir. Considerando ainda que os colonos são tratados no mais das vezes em função do tema da evangelização do indígena, podemos compreender a predominância da imagem conflituosa da relação entre jesuítas e colonos na correspondência.

As cartas que apresentam informações a respeito do planalto paulista provêm, em sua maioria, das penas de Manuel da Nóbrega, José de Anchieta, Leonardo Nunes, Pero Correia e Baltasar Fernandes. São elas enviadas tanto de Piratininga quanto de São Vicente, já que, na maior parte das vezes, os assuntos tratados seguem o recorte da capitania como um todo. A primeira carta proveniente da capitania de São Vicente foi escrita pelo padre Leonardo Nunes,

\footnotetext{
${ }^{90}$ ARSI, Lus. 69, f. 133v, grifos presentes no manuscrito.

91 ARMAS, Antonio Rumeu de. "Una carta inédita del apostol del Brasil, beato José de Anchieta, al rey Felipe II”, Anuário de estudos Atlânticos, 43. Madrid/Las Palmas, 1997, p. 11.

${ }^{92} \mathrm{MB}$ III, p. 28.

93 Janice Teodoro da Silva apontou, dentre os problemas em se utilizar as cartas jesuíticas no estudo dos primórdios de São Paulo, o das omissões (São Paulo: 1554-1880: discurso ideológico e organização espacial. São Paulo: Editora Moderna, 1984, p. 17).
} 
a ela enviado por Nóbrega em fins de 1549 com dez ou doze meninos ${ }^{94}$. Nesta carta, o padre relata já a entrada que realiza ao sertão para tratar com os cristãos que estavam espalhados no lugar e com os índios que tinham suas aldeias no Campo ${ }^{95}$. Dentre os motivos apontados para o estabelecimento de uma casa, posteriormente colégio, destacam-se: o objetivo de estabelecer contato com as populações indígenas do interior, a melhor condição de sustentação no planalto, a distância em relação aos portugueses e a própria distribuição espacial dos índios na capitania, com as aldeias localizadas nesta região ${ }^{96}$. Após a fundação da casa de Piratininga em 25 de janeiro de 1554, ficou por superior o padre Manuel de Paiva e, como professor de latim, o irmão José de Anchieta ${ }^{97}$. Serafim Leite esforça-se em atribuir a fundação de São Paulo ao padre Manuel da Nóbrega, recuando-a para o ano de 1553. Raquel Glezer relaciona o debate quanto ao "verdadeiro" fundador ao que denomina "mito de origem" (a leitura do passado da cidade em função de sua proeminência posterior, característica fundamental de grande parte dos estudos a respeito do período colonial paulista), como se o fundador tivesse impingido seus traços de caráter, atuação e personalidade à cidade que se desenvolveu posteriormente ${ }^{98}$.

\subsection{O lugar dos colonos do planalto paulista nas cartas jesuíticas}

Considerando-se os diversos condicionantes que organizam o tratamento dos temas nas cartas jesuíticas do Brasil, como discutido no tópico anterior, resta agora situar mais pormenorizadamente o colono no interior da estrutura formal, retórica e teológico-política desses textos. O procedimento de isolar os trechos referentes aos colonos e neles buscar informações não permitiria mais do que repetir a avaliação institucional da Companhia acerca daquele processo histórico. Outro risco a ser evitado é o de tomar isoladamente as narrativas sobre os colonos do planalto, dado que algumas problemáticas observáveis na correspondência não são exclusividade da região. Esse recorte arbitrário, bastante comum nos

\footnotetext{
${ }^{94}$ LEITE, Serafim, S. J. História da Companhia de Jesus no Brasil, tomo I. Lisboa: Livraria Portugália; Rio de Janeiro: Civilização Brasileira, 1938, p. 252.

${ }^{95}$ MB I, pp. 200-10.

${ }^{96}$ LEITE, op. cit., pp. 260-70.

${ }^{97}$ Ibid. 273.

${ }^{98}$ GLEZER, Raquel. Chão de terra e outros ensaios sobre São Paulo. São Paulo: Alameda, 2007, pp. 42-4.
} 
estudos referentes à vila de São Paulo, faz parte de uma influente tradição historiográfica, que analisaremos mais adiante.

Primeiramente, é imprescindível considerar que as cartas, notadamente aquelas de teor edificante, focavam-se no trabalho de evangelização do gentio, não sendo os colonos muitas vezes sequer citados, o que não correspondia - ou pelo menos não sempre - à real proporção da divisão cotidiana da atividade ministerial entre índios e população branca ou mestiça. Na maioria das vezes em que o colono é citado, aparece relacionado a este tema principal. Dentre as construções em que os colonos mais frequentemente aparecem nesses textos, podemos destacar: a comparação com o indígena, no que se refere à boa disposição para o entendimento da fé e para a vida cristã; a denúncia dos "danos" causados aos gentios, centrada na questão do cativeiro injusto; o "mau exemplo" que seus costumes constituíam para essas populações que se buscava evangelizar. Há, contudo, algumas vezes em que a atividade ministerial com a população branca não é descrita em função do indígena. Nesses casos, o mais comum é que se tratasse de um relato da atividade do padre ou irmão em questão, apresentando-o como empenhado e obediente cumpridor do Instituto da Companhia, ou de algum episódio de interesse particular ou piedoso. Algumas das cartas das décadas de 1570 e 1580, período em que o aspecto prático-administrativo predomina na correspondência preservada, apresentam uma divisão bem menos desigual na abordagem do trabalho com os indígenas e os portugueses. Estas cartas possibilitam-nos recuperar alguns pormenores dificilmente presentes nas edificantes dos períodos anteriores, desde que consideremos as mudanças pelos quais a estratégia de evangelização e a sustentação das casas e colégios passaram durante o período. As "Informações" e relatos de viagem também apresentam diferenças na maneira de abordar os colonos, como veremos.

Ao descreverem sua própria atuação no Brasil, os jesuítas ordinariamente elencam lado a lado o trabalho com portugueses e indígenas. Nesse sentido há até mesmo uma espécie de "fórmula" utilizada constantemente: "tanto índios como portugueses", a qual indica o zelo ministerial em todas as esferas possíveis. Todavia, essa constatação genérica raramente se desenvolve em uma descrição circunstanciada das atividades com os portugueses e episódios exemplificadores, como quando se aborda os "danos" que provocam aos índios. Há ocasiões em que a evangelização do indígena vem expressa como a motivação principal da presença jesuítica no Brasil, em detrimento do branco ${ }^{99}$. É necessário, nas duas situações, analisar o

\footnotetext{
${ }^{99}$ MEIHY, José Carlos Sebe Bom. A presença do Brasil na Companhia de Jesus (1549-1649). 1975. 255 f. Tese (Doutorado em História Social) - Faculdade de Filosofia, Letras e Ciências Humanas, Universidade de São Paulo, São Paulo, 1975, p. 237.
} 
contexto retórico em que se inserem as afirmações. O padre Manuel da Nóbrega apresenta um exemplo bastante revelador deste procedimento. Em uma carta datada de setembro de 1551, enviada de Pernambuco, o padre afirma: "Destes escravos e das pregações corre a fama às Aldeas dos Negros, de maneira que vem a nós de muy longe a ouvir nossa pratica. Dizemoslhe que por seu respeito principalmente viemos a esta terra e não por os brancos". Mais abaixo, vale-se da "fórmula" apontada ao descrever suas atividades na vila e, ao final da carta, admite não terem conseguido se dedicar muito aos índios:

Eu prego domingos e festas duas vezes a toda a gente da Villa, que hé muyta, e às sextas-feiras tem pratica com disciplina com que se muyto aproveitão todos. Vão-se confessando e juntamente fazendo penitencia; asi em brancos como nos Indios há grande fervor e devação.

[...] Até agora pouco podemos conversar ho gentio, porque os christãos estavão taes que nos occupão muyto suas confissões e negocios com elles ${ }^{100}$.

Embora a Companhia tenha sido enviada ao Brasil para a conversão do gentio, sua atuação é, em muitos sentidos, condicionada pela ocupação portuguesa e ligada ao aparato institucional dessa realidade ${ }^{101}$. Mesmo após a elevação do Brasil a província, passando a responder diretamente à direção romana da ordem, a atuação dos jesuítas não se desenvolverá independentemente das condições práticas proporcionadas pela ocupação portuguesa. Ainda assim, o fundamento de sua presença estará sempre no horizonte dos missionários, e a correspondência é profundamente marcada por tal fundamento. Os irmãos que aguardam ansiosamente pelas cartas dos missionários, bem como o público mais amplo em que elas circulam, não esperam ler a respeito do cotidiano das aulas, pregações e administração de sacramento aos portugueses, mortificações dos irmãos etc., com a mesma intensidade com que esperam informações a respeito do canibalismo, costumes alimentares e conjugais, crenças e a maneira como Deus revela sua presença nos muitos episódios edificantes narrados e nas muitas almas que se espera conquistarem para Cristo.

A descrição dos hábitos dos colonos, por sua vez, cumpre frequentemente uma função retórica mais pontual. Quando a carta condena o cativeiro injusto dos indígenas pelos colonos, as descrições destes últimos são bastante mais negativas, mesmo em relação a temas tratados frequentemente, como a constante prática da mancebia. Da mesma forma, quando se

\footnotetext{
${ }^{100}$ MB I, p. 288-9, grifo nosso. A palavra "negro" tem aqui a acepção de índio, o "negro da terra" e não o "negro da Guiné".

101 "No caso dos jesuítas, é necessário ter presente que a sua obra foi fortemente influenciada pela cultura e pelo poder dominantes na sociedade portuguesa" (PROSPERI, Adriano. "As missões no Brasil, vistas de Roma". Comunicação apresentada no Colóquio internacional Contextos missionários: Religião e poder no Império português, realizado na Universidade de São Paulo, 1-5 de outubro de 2007, p. 3).
} 
defende e se solicita autorização para a entrada no sertão, acentuam a ineficácia do trabalho ministerial entre os portugueses pela indisposição destes, o que tem a óbvia função retórica de justificar a empreitada: "Ya cansamos de clamar, ya los que nos avían de oir, de los christianos, nos tienen oydo, no nos queda más que la gentilidad, y si ésta nos impiden, no haremos nada" ${ }^{\prime 102}$. Sendo assim, é na comparação (e não na simples acumulação de trechos) entre as diversas maneiras de se abordar um tema nas cartas que podemos estabelecer as modalidades em que se dava a relação dos jesuítas com os colonos e o que elas podem revelar em relação às práticas religiosas destes últimos.

Nas cartas jesuíticas de todas as capitanias do Brasil é bastante comum a utilização de um tipo específico de comparação entre índios e colonos. Esta comparação apresentava o índio como superior ao branco em sua devoção, entendimento ou costumes, a depender do caso. Não se trata de uma comparação analítica, mas sim de um recurso retórico que acentua com enorme capacidade expressiva a boa disposição dos indígenas para o cristianismo, o que é possível visualizar na maneira genérica com que era utilizada. São muitas as cartas que trazem esse tipo de argumentação, mas encontramos no famoso Diálogo sobre a conversão do gentio do P. Manuel da Nóbrega sua utilização mais emblemática, uma vez que a obra discute justamente a disposição do "gentio" para o cristianismo, fornecendo uma avaliação ampla da situação da atividade missionária no Brasil. Quando Matheus Nugueira, um dos interlocutores do diálogo, argumenta a favor da igual condição natural de entendimento a todas as "gerações", afirma que os padres "achão [os filhos dos indígenas] de tão boom entendimento que muitos fazem avantagem aos filhos dos christãos". Tal comparação é utilizada na correspondência, nos mesmos moldes, para se referir à lealdade, fervor religioso, costumes etc. Trata-se, portanto, de mais uma espécie de "fórnula" utilizada pelos jesuítas que, com muita probabilidade, dialogava com a opinião corrente a respeito da pouca capacidade do indígena. É contra essa opinião que se direciona toda a argumentação do Diálogo escrito por Nóbrega.

A relação entre jesuítas e colonos foi profundamente marcada pelo conflito em torno da assimilação da população indígena. A historiografia mais tradicional, notadamente aquela ligada à própria Companhia de Jesus, esquematizou esse conflito contrapondo colonos escravistas e jesuítas defensores da liberdade indígena, construção que foi baseada, no que tange ao século XVI, principalmente na leitura das cartas jesuíticas. O problema da escravização dos índios era, contudo, bastante mais complexo, como demonstrou a

\footnotetext{
${ }^{102}$ Carta de Manuel da Nóbrega ao padre Luís Gonçalves da Câmara, datada de 15 junho de 1553 (MB I, p. 502).
} 
fundamental pesquisa de Carlos A. Zeron sobre o papel da escravidão indígena na Companhia de Jesus ${ }^{103}$. Mesmo que o conflito entre colonos e jesuítas não possa ser reduzido ao dualismo liberdade/escravidão, a diferença nas modalidades de assimilação dos nativos como mão de obra levou, já no século XVI, a uma tensão entre essas duas esferas da presença colonial no Brasil. Nesse sentido, a situação do planalto paulista, ainda que com suas particularidades, não diferia em linhas gerais do que sucedia em outras capitanias, como se pode visualizar na correspondência ${ }^{104}$.

Todavia, este conflito, como afirma John Monteiro, "não se materializou imediatamente, uma vez que antes se fazia necessária, para a permanência dos invasores em solo indígena, a colaboração entre colonos e jesuítas perante a resistência dos índios" ${ }^{105}$. Em toda a capitania de São Vicente, as dificuldades geradas pela Guerra dos Tamoios, em meados do século, tornaram essa colaboração uma questão de sobrevivência, ainda que as diferenças de opinião em relação ao cativeiro indígena se fizessem presentes. O fim do século XVI, com o fracasso da experiência jesuíta dos aldeamentos, assinala o início de uma nova fase nas relações euro-indígenas, que representa também um novo delineamento para o conflito entre jesuítas e colonos. É imprescindível estar atento, ao se buscar na correspondência jesuítica informações sobre os colonos do planalto, às características desse cenário mais amplo.

A maneira como os colonos aparecem nas cartas apresenta, no caso de São Paulo quinhentista, uma problemática peculiar. Essas referências documentais foram lidas repetidamente sob o viés do persistente e influente paradigma historiográfico da especificidade $^{106}$ paulista no contexto colonial. Não seria possível refazer aqui o complexo percurso da construção desse paradigma, hoje já um tanto envelhecido. Entretanto, por encontrarmos ecos dessa leitura mesmo em trabalhos bastante recentes, é necessário destacar sinteticamente alguns direcionamentos que essa ideia assumiu na historiografia. Para compreender o papel dos paulistas nas narrativas epistolares jesuíticas do século XVI é preciso decompor essas camadas interpretativas, construídas principalmente a partir de situações referentes aos séculos posteriores.

\footnotetext{
${ }^{103}$ ZERON, Carlos Alberto de M. R. Ligne de foi: La compagnie de Jésus et l'esclavage dans le processus de formation de la société coloniale en Amérique portugaise (XVIe-XVIIe siècles). Paris: Honoré Champion Éditeur, 2009. Na introdução (pp. 17-38), o autor faz uma síntese crítica da historiografia referente ao tema, indicando a leitura enviesada dos autores ligados à própria Companhia de Jesus, bem como de outros que também seguem esta leitura.

${ }^{104}$ John M. Monteiro analisa a situação específica do planalto paulista no subitem "Jesuítas e Colonos na ocupação do Planalto", in: Negros da Terra: índios e bandeirantes nas origens de São Paulo. São Paulo: Companhia das Letras, 1994, pp. 36-42.

${ }^{105}$ Ibid., p. 38.

106 Termo utilizado por Ilana Blaj no artigo "Mentalidade e Sociedade: revisitando a historiografia sobre São Paulo colonial”. Revista de História da Universidade de São Paulo, n. 142-143, $1^{\circ}$ sem. 2000, pp. 239-259.
} 
A utilização da ideia de especificidade paulista pela historiografia não diz respeito, na maioria das vezes, às peculiaridades que cada região obviamente possuía no interior de um contexto colonial mais amplo. Um grande número de autores, de tendências variadas, procurou apresentar o planalto paulista como uma região única na América portuguesa, praticamente alheia ao que poderíamos tomar conjuntamente como Brasil colonial. Nesse sentido, compartilham esse paradigma tanto os autores que buscam louvar a independência e autossuficiência paulistas, quanto aqueles que destacam a pobreza material da região e sua marginalidade na estrutura colonial. Com o objetivo de avaliar criticamente a ideia da especificidade paulista, Ilana Blaj aponta essa convergência entre as tendências desenvolvidas a partir da virada do século XX por autores ligados ao Instituto Histórico e Geográfico de São Paulo (IHGSP) e as abordagens utilizadas a partir da década de 1950:

Seja enaltecendo a independência, altivez, rebeldia do paulista e a fartura de sua lavoura auto-suficiente (visão do IHGSP), seja ressaltando a pobreza de sua economia de subsistência e as dificuldades de enriquecimento de sua população (abordagens a partir da década de cinqüenta), São Paulo colonial tem sido apresentada como uma formação peculiar, atípica, diferenciada com relação às áreas exportadoras escravistas ${ }^{107}$.

A autora tem o objetivo de inserir São Paulo na estrutura senhorial-escravista que entende como característica de toda a América portuguesa, baseada na propriedade, escravidão e símbolos de honraria e prestígio. Aponta também as motivações políticas ligadas à utilização historiográfica da especificidade paulista entre 1930 e 1945, notadamente pelos escritos ligados ao IHGSP. A imagem do paulista altivo, desbravador e autossuficiente, tendo como fundamento o bandeirante, ligou-se profundamente à situação econômica e às pretensões políticas da São Paulo cafeeira no Estado Novo, e havia sido gestada no interior de uma visão republicana da História da região que vinha sendo esboçada desde as últimas décadas do século XIX ${ }^{108}$. Teremos a ocasião de acompanhar mais detidamente no próximo tópico, sobre o caso de João Ramalho, como essa abordagem - que podemos chamar mais

\footnotetext{
107 BLAJ, Ilana. "Mentalidade e Sociedade: revisitando a historiografia sobre São Paulo colonial", Revista de História da Universidade de São Paulo, n. 142-143, 1 sem. 2000, p. 242.

108 "Assim, o que predomina e permanece nos escritos do Instituto Histórico e Geográfico de São Paulo, entre 1930 e 1945, é menos a imagem do isolamento do que a da auto-suficiência. São Paulo seria uma verdadeira autarquia que não necessitava da Metrópole, vale dizer, do poder central em 1930; não necessitava, igualmente, das outras regiões, logo dos outros Estados; em suma, São Paulo e os paulistas sobreviveram galhardamente no período colonial como sobreviviam heroicamente durante o Estado Novo". Ibid., p. 241. Sobre o desenvolvimento inicial dessa autoimagem paulista a partir de fins do século XIX, conferir a detalhada pesquisa de Danilo José Z. Ferretti. A construção da paulistanidade: identidade, historiografia e política em São Paulo (1856-1930). 2004. 391 f. Tese (Doutorado em História Social) - Faculdade de Filosofia, Letras e Ciências Humanas, Universidade de São Paulo, São Paulo, 2004, principalmente a parte II, pp. 102-250.
} 
genericamente de historiografia paulística, ainda que não fosse homogênea ${ }^{109}$ - enviesou a leitura da correspondência jesuítica do século XVI.

A construção da ideia de especificidade paulista teve como um dos fundamentos as constantes referências documentais à insubmissão dos colonos do planalto às autoridades e legislação real, tendo como cerne a questão da utilização da mão de obra indígena e, como principais propagadores dessa imagem, os jesuítas. Como afirma John Monteiro:

[...] desde meados do século XVII, diversos observadores sublinharam a suposta autonomia e rebeldia dos colonos de São Paulo, sobretudo em função da sua franca desobediência às leis do Reino referentes à liberdade dos índios. Certamente esta tendência começou a ser fomentada pelos jesuítas durante os conflitos em torno das missões de Guairá ${ }^{110}$.

Nas cartas jesuíticas quinhentistas encontramos referências a conflitos entre missionários da Companhia e colonos do planalto, mas em moldes diversos do que podemos visualizar nas descrições posteriores. Segundo John Monteiro, a própria utilização do termo paulista remonta ao século XVII, adquirindo contornos mais definidos nas narrativas referentes ao conflito dos emboabas, durante o século XVIII, nos quais ora era possível distinguir um habitante da vila de São Paulo de um habitante de Taubaté, ora essas diferenças eram diluídas em um uso mais genérico do termo, que incluía todos os habitantes de Serra Acima $^{111}$. Na defesa de uma especificidade paulista, seja pelo viés da rebeldia como da autossuficiência, é frequente a extensão do conceito ao século XVI, tomando a documentação de um e outro período como complementares, o que acaba por diminuir a importância das modificações econômicas, populacionais e administrativas pelas quais a região do planalto passou a partir da década de $1580^{112}$.

\footnotetext{
${ }^{109}$ Danilo Ferretti aponta a necessidade de evitar uma leitura focada apenas em um recorte social, como "elite paulista", uma vez que dilui as importantes clivagens políticas e subdimensiona a importância de autores que contestam a vertente perrepista (A construção da paulistanidade: identidade, historiografia e política em São Paulo (1856-1930). 2004. 391 f. Tese (Doutorado em História Social) - Faculdade de Filosofia, Letras e Ciências Humanas, Universidade de São Paulo, São Paulo, 2004, principalmente a parte II, p. 5).

${ }^{110}$ MONTEIRO, John. Tupis, Tapuias e historiadores: Estudos de História indígena e do indigenismo. 2001. 233 f. Tese (Livre Docência em Etnologia) - Instituto de Filosofia e Ciências Humanas, Unicamp, Campinas, 2001, pp. 105-6.

${ }_{111}$ MONTEIRO, Ibid., p. 109.

112 Em relação a esse tema, o trabalho fundamental é MONTEIRO, John Manuel. Negros da Terra: índios e bandeirantes nas origens de São Paulo. São Paulo: Companhia das Letras, 1994. Cf. ainda a recente pesquisa de José Carlos Vilardaga. São Paulo na órbita do Império dos Felipes: Conexões castelhanas de uma vila da América portuguesa durante a União Ibérica (1580-1640). 2010. 399 f. Tese (Doutorado em História Social) Faculdade de Filosofia, Letras e Ciências Humanas, Universidade de São Paulo, São Paulo, 2011.
} 
A imagem de uma vila autônoma politicamente e marginal economicamente esteve profundamente ligada à ideia de isolamento geográfico ${ }^{113}$. De fato, as dificuldades de acesso ao planalto paulista pela Serra do Mar são bem conhecidas e são citadas inclusive pela documentação jesuítica aqui analisada ${ }^{114}$. Essa situação geográfica, associada às acusações de insubmissão dos colonos da região, foi fundamental na elaboração do paradigma da especificidade paulista. A leitura da História de São Paulo tendo como traço constitutivo o isolamento foi bastante explorada por autores como Afonso Taunay, Alcântara Machado, Washington Luiz e Alfredo Ellis Jr. ${ }^{115}$. Atribuiu-se ainda ao isolamento a formação de uma "raça paulista", mestiça e tendo como uma das principais qualidades o sentimento de independência ${ }^{116}$. Para tratar de maneira pertinente dos reflexos dessa situação geográfica na vida dos colonos do planalto, é preciso, em primeiro lugar, evitar a associação automática do isolamento à imagem do paulista rebelde e autossuficiente, e, em segundo lugar, analisar mais pormenorizadamente as ligações da vila de São Paulo com outras regiões, dimensionando melhor o quanto a região seria ou não isolada.

Algumas pesquisas articularam a ideia de isolamento geográfico à questão da pobreza do planalto no campo da vida material. Alcântara Machado debruçou-se sobre os inventários e testamentos para apresentar um quadro dos objetos que faziam parte do cotidiano dos desbravadores do sertão ${ }^{117}$. Mais recentemente, Carlos A. C. Lemos leva adiante essa proposta analítica ${ }^{118}$. Estas pesquisas apontam, em relação aos séculos XVI e XVII, para um cotidiano pobre, caracterizado por "um repertório de bens culturais, além de modesto, calcado em repetições de soluções antigas" $" 119$, gerando situações curiosas como o caso do vestido de seda e de veludo preto lavrado de Isabel Ribeiro, avaliado como cinco vezes mais valioso que sua casa assobradada na Rua Direita ${ }^{120}$. Afonso Taunay havia já tratado rapidamente da "desproporção" entre os valores de bens imóveis e manufaturados,

\footnotetext{
${ }^{113}$ VILARDAGA, José Carlos. São Paulo na órbita do Império dos Felipes: Conexões castelhanas de uma vila da América portuguesa durante a União Ibérica (1580-1640). 2010. 399 f. Tese (Doutorado em História Social) Faculdade de Filosofia, Letras e Ciências Humanas, Universidade de São Paulo, São Paulo, 2011, p. 190.

${ }^{114}$ MB II, p. 159, 316.

${ }^{115}$ VILARDAGA, loc. cit.

116 Ilana Blaj analisa como Paulo Prado desenvolve essa articulação (A trama das tensões: O processo de mercantilização de São Paulo colonial (1681-1721). São Paulo: Humanitas/FFLCH/USP: Fapesp, 2002, pp. 445).

${ }^{117}$ MACHADO, Alcântara. Vida e morte do bandeirante. São Paulo: Imprensa Oficial do Estado de São Paulo, 2006 [1929].

${ }^{118}$ LEMOS, Carlos A. C. "Notas sobre a cultura material e o cotidiano em São Paulo nos tempos coloniais". In: PORTA, Paula (org.) História da Cidade de São Paulo, v.1: a cidade colonial. São Paulo: Paz e Terra, 2004, pp. 179-189.

${ }^{119}$ Ibid., p. 180.

${ }^{120}$ Ibid., p. 179.
} 
apontando também a pobreza material da vila nos séculos XVI e XVII ${ }^{121}$. Taunay e Alcântara Machado apontam a dificuldade causada pelo transporte através da serra, bem como do marítimo, mas destacam a falta de uma atividade econômica pulsante como fundamento dessa carência de produtos europeus ${ }^{122}$. No entanto, Taunay destaca ainda que, mesmo nas regiões mais opulentas, não havia à época uma diversidade muito grande de utensílios ${ }^{123}$. O "isolamento de serra-acima" como fundamento dessa carência, sem que se desconsidere a influência da pobreza, recebe maior destaque no texto de Carlos Lemos ${ }^{124}$.

Decerto a vida em São Paulo era bastante modesta, como atestam os inventários e testamentos, principalmente até a última década do século XVI, quando sobrevém um relativo incremento econômico. A dificuldade em se transportar os produtos pelo caminho do mar, às costas dos índios, certamente valorizava ainda mais os produtos europeus. No entanto, se a carência de bens está fartamente documentada, o mesmo não se pode dizer de sua ligação com o pretenso isolamento do planalto, para qual consideramos haver ainda uma influência da tradição historiográfica da especificidade paulista. Os trabalhos indicados dedicam, por exemplo, uma atenção marginal à explicação dada por Fernão Cardim de que havia uma "grande falta de vestido" na vila de São Paulo "porque não vão os navios a S. Vicente senão tarde e poucos" ${ }^{\prime 25}$. Trata-se, evidentemente, de uma referência isolada, que não deve ser sobrevalorizada, mas que permite conjecturar outras possibilidades explicativas.

José Carlos Vilardaga realizou uma análise mais detida das relações comerciais da vila de São Paulo durante a União Ibérica (1580-1640). A quantidade de ligações comerciais e empreendimentos em outras regiões, por parte de alguns moradores, coloca alguns questionamentos ao binômio pobreza-isolamento. Um caso representativo é o de Afonso Sardinha, residente em São Paulo desde 1565, tratado por Afonso Taunay como exceção em meio ao contexto de pobreza ${ }^{126}$. É sempre lembrado o episódio em que justifica sua ausência em uma sessão da Câmara por não ter botas. Ainda assim, possuía negócios em Santos, Rio de Janeiro e Buenos Aires, deslocando-se frequentemente "ao mar". "Negociava escravos da

121 TAUNAY, Afonso de E. São Paulo nos primeiros anos (1554-1601): ensaio de reconstituição social; São Paulo no Século XVI: história da vila piratiningana. Coordenação de Paula Porta. São Paulo: Paz e Terra, 2003 [1920, 1921], pp. 155-8. O autor recorre aos inventários e testamentos do século XVII por não ter restado quase nenhum do século anterior, objeto do livro.

${ }^{122}$ Ibid., p. 156 e 180; MACHADO, Alcântara. Vida e morte do bandeirante. São Paulo: Imprensa Oficial do Estado de São Paulo, 2006 [1929], p. 40.

123 TAUNAY, op. cit., p. 158.

${ }^{124}$ LEMOS, Carlos A. C. "Notas sobre a cultura material e o cotidiano em São Paulo nos tempos coloniais". In: PORTA, Paula (org.) História da Cidade de São Paulo, v.1: a cidade colonial. São Paulo: Paz e Terra, 2004, passim.

${ }^{125}$ CARDIM, Fernão. Tratados da terra e gente do Brasil. Introduções e notas de Baptista Caetano, Capistrano de Abreu e Rodolpho Garcia. Rio de Janeiro: J. Leite \& Cia., 1925, p. 357.

${ }^{126}$ TAUNAY, op. cit., p. 157. 
Guiné, tecidos, marmelada e gentios. Foi de sua propriedade um dos primeiros trapiches de açúcar no planalto"127. Para o nosso período, Vilardaga apresenta diversos exemplos da utilização do caminho que ligava São Vicente ao Paraguai através de São Paulo, desde a década de $1550^{128}$. O tema do isolamento geográfico da vila de São Paulo, portanto, está longe de ser esgotado, e o paradigma da especificidade paulista ainda pesa sobre muitas análises.

Cabe aqui uma observação a respeito da utilização das referências epistolares jesuíticas para justificar a ideia de isolamento. Recorre-se com frequência aos trechos relativos à dificuldade de acesso ao planalto como indicação da falta de contato com a metrópole, do que nos dá notável exemplo uma passagem de Ernani Silva Bruno:

De sua localização em planalto de acesso difícil resultou a falta de contacto da capitania tôda com a Metrópole desde os tempos coloniais. Já em sua Informação de 1585 escrevia Anchieta: "A quarta vila na capitania de São Vicente é Piratininga, que está dez a doze léguas pelo sertão e terra a dentro. Vão lá por umas serras tão altas que dificultosamente podem subir nenhuns animais, e os homens sobem com trabalho e às vezes de gatinhas por não despenharem-se, e por ser o caminho tão mau e ter ruim serventia padecem os moradores e os nossos grandes trabalhos" $" 129$.

A passagem de Anchieta acentua o quão dificultoso era o caminho até o planalto, o que permite, por sua vez, valorizar o esforço dos missionários. Porém, longe de indicar o isolamento de São Paulo, o texto alude justamente à efetiva utilização do caminho. Se tanto "moradores" quanto jesuítas "padecem grandes trabalhos", é porque de fato percorriam o trajeto, ainda que não seja possível saber a frequência. Não é o caso de concluir daí que a movimentação entre a costa e o planalto fosse corriqueira, mas o documento tampouco indica que era rara. É possível entrever também nesta leitura que Silva Bruno faz da Informação uma projeção das temáticas seiscentistas ligadas ao paulista, nas quais se relacionavam isolamento e insubmissão. O autor efetivamente faz a ponte entre os temas já na página seguinte.

Uma indicação semelhante, com mais pormenores, está presente na narrativa epistolar de Fernão Cardim acerca da visitação do padre Cristóvão de Gouveia às partes do Brasil, realizada entre 1583 e 1590 . Cardim também menciona que o caminho para Piratininga

\footnotetext{
${ }^{127}$ VILARDAGA, José Carlos. São Paulo na órbita do Império dos Felipes: Conexões castelhanas de uma vila da América portuguesa durante a União Ibérica (1580-1640). 2010. 399 f. Tese (Doutorado em História Social) Faculdade de Filosofia, Letras e Ciências Humanas, Universidade de São Paulo, São Paulo, 2011, p. 116. É o autor que chama a atenção para a incongruência entre o episódio das botas e as extensas ligações comerciais de Sardinha. Para as ligações da vila de São Paulo na América Meridional, conferir o capítulo 3, pp. 189-280.

128 Ibid., p. 222.

129 BRUNO, Ernani Silva. História e tradições da cidade de São Paulo, vol. I: Arraial de sertanistas (15541828). Rio de Janeiro: Livraria José Olympio Editôra, 1953, pp. 38-9.
} 
era "tão íngreme que às vezes íamos pegando com as mãos", "o peor que nunca vi”,"130, repleto de brejos, com subidas e descidas constantes. Como na Informação de Anchieta, não há menção a isolamento, apenas à dificuldade do trajeto. $O$ texto chega a fazer uma referência sutil à existência de um contato não tão espaçado entre os jesuítas de São Vicente e Piratininga. Escreve Cardim que a partida para São Paulo ocorreu porque "desejavam os padres de Piratininga que o padre visitador se achasse naquella casa aos 25 de Janeiro, dia da conversão de S. Paulo, por ser orago da nossa igreja"131. Dado que a chegada de Gouveia e Cardim a São Vicente deu-se já em meados de janeiro, a informação correu com relativa rapidez. Em 1550, antes mesmo da fundação da casa de Piratininga e da vila de Santo André da Borda do Campo, Leonardo Nunes narra um episódio semelhante. Dirigindo-se ao Campo, por tomar conhecimento da "gente christiana derramada" ali, "en la postrera jornada topamos un mancebo con unas cartas para mí, que me estavan esperando, porque ya tenían nuevas que yo desseava de les yr a ver" ${ }^{132}$. Insistimos, contudo, que casos pontuais como os citados não permitem concluir a existência de um tráfego intenso de moradores entre o planalto e a costa. São apenas indícios de que a ligação de Santo André e São Paulo com o litoral precisa ser dimensionada sem uma adequação prévia à ideia de isolamento, que leva a enxergar nas fontes mais do que elas efetivamente apresentam. A quantidade de vezes em que as atas da Câmara mencionam a ida de alguém "ao mar", mesmo com o espaçamento entre as reuniões, indica que a frequência desse deslocamento poderia ser maior do que ordinariamente se apresenta $^{133}$.

É importante considerar ainda que, se a situação geográfica do planalto paulista tornava o acesso trabalhoso, também fazia da região uma passagem fundamental entre o litoral vicentino e o interior do continente, como já indicara Caio Prado Júnior em estudo clássico $^{134}$, uma vez que o obstáculo da Serra do Mar era ali mais facilmente ultrapassado. Atingir o Paraguai a partir de São Vicente, através do planalto paulista, não era um caminho pouco usual, mesmo que fosse proibido, e foi o trajeto escolhido até mesmo por Luis de Céspedes e Xeria para assumir o governo do Paraguai em 1628, bem como por diversos

\footnotetext{
${ }^{130}$ CARDIM, Fernão. Tratados da terra e gente do Brasil. Introduções e notas de Baptista Caetano, Capistrano de Abreu e Rodolpho Garcia. Rio de Janeiro: J. Leite \& Cia., 1925, p. 353.

131 Ibid., p. 352.

132 MB I, p.209.

${ }^{133}$ Cf., dentre outras: ACVSP (24/06/1575, 14/08/1575, 02/09/1581); e na Câmara de Santo André da Borda do Campo, em 28/09/1555 (“Actas da Camara de Santo André da Borda do Campo”. In: TAUNAY, Afonso de E. João Ramalho e Santo André da Borda do Campo. São Paulo: Publicação comemorativa do Quarto Centenário da Fundação de Santo André da Borda do Campo, 1953, p. 273.

${ }^{134}$ PRADO Jr., Caio. "O fator geográfico na formação e no desenvolvimento da cidade de São Paulo". In: Evolução política do Brasil e outros estudos. São Paulo: Editora Brasiliense, 1953, pp. 99-118.
} 
"aventureiros e conquistadores", ainda no século XVI ${ }^{135}$. A listagem que José Carlos Vilardaga apresenta de indivíduos que cruzaram o caminho ilegal de São Paulo ao Paraguai durante a União Ibérica indica, por sua vez, que se tratava de uma ligação com alguma constância $^{136}$.

Dessa forma, para se compreender o planalto paulista no século XVI é necessário, além de problematizar o paradigma da especificidade, analisar detidamente a situação concreta no que concerne aos respectivos temas. Ao se problematizar o viés ideológico da utilização historiográfica da especificidade paulista, e a visão exageradamente homogênea que apresenta em relação às outras regiões da colônia, as questões como o isolamento e a pobreza material do planalto, a liberdade política e a economia de subsistência não estão automaticamente resolvidas. Ainda que não se procure construir uma oposição entre São Paulo e o restante do Brasil tomado em conjunto, entender as peculiaridades do processo histórico da colonização do planalto é certamente fundamental para compreender o posterior desenvolvimento histórico da região.

O enfoque das pesquisas de Sérgio Buarque de Holanda sobre São Paulo é representativo dessa problemática. Em certa medida, ressoam em seus trabalhos algumas das imagens tradicionais atribuídas aos paulistas, "que chegaram a aclamar um rei de sua casta e dos quais dizia certo governador português que formavam uma república de per si,

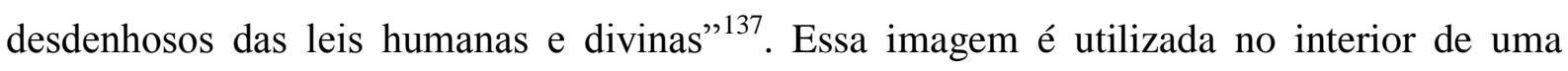
argumentação que busca identificar o que a realidade interiorana tem de peculiar em relação ao que seria o padrão mais difundido nas cidades costeiras ${ }^{138}$. Tal interpretação guarda certa semelhança com a contraposição entre o paulista rebelde e o habitante da costa que Ilana Blaj critica na historiografia paulística, que peca por uma simplificação da realidade costeira e das relações entre a sociedade paulista e as estruturas monárquicas de poder:

Portanto, conjunturalmente, as relações entre paulistas e autoridades reais podiam ser conflituosas, como também o foram, nas mesmas condições, nas demais regiões do país. Mas, ao fim e ao cabo, a conciliação era sempre possível pois, como já apontamos, eram os mesmos objetivos que todos

\footnotetext{
${ }^{135}$ VILARDAGA, José Carlos. São Paulo na órbita do Império dos Felipes: Conexões castelhanas de uma vila da América portuguesa durante a União Ibérica (1580-1640). 2010. 399 f. Tese (Doutorado em História Social) Faculdade de Filosofia, Letras e Ciências Humanas, Universidade de São Paulo, São Paulo, 2011, p. 221.

136 Ibid., pp. 394-9.

${ }^{137}$ HOLANDA, Sérgio Buarque de. Caminhos e fronteiras. $3^{\text {a }}$ ed. São Paulo: Companhia das Letras, 1994 [1956], p. 21.

${ }^{138}$ Essa perspectiva comparativa entre realidade costeira e interiorana está presente no conjunto desse trabalho, que focaliza a vida material (Ibidem).
} 
perseguiam, quais sejam, o desenvolvimento da colonização e a sedimentação da ordem senhorial-escravista ${ }^{139}$.

Na interpretação de Buarque de Holanda, no entanto, a perspectiva comparativa entre interior e litoral cumpre uma função diversa do que cumpria na historiografia paulística. A diferença entre a realidade interiorana e a das cidades costeiras não é atribuída pelo autor às características especiais de uma "raça paulista", mas à necessidade de adaptação a condições muito diversas do meio. Não lhe escapam, contudo, os traços comuns que tornavam as duas realidades parte de um mesmo processo histórico, perspectiva que Ilana Blaj aponta como ausente nos autores da vertente paulística e naqueles de derivação cepalina. Segundo Buarque de Holanda, "em toda parte é idêntico o objetivo dos colonos portugueses. Diverge unicamente, ditado pelas circunstâncias locais, o compasso que, num e noutro caso, regula a marcha para esse objetivo" ${ }^{140}$. Em Caminhos e fronteiras, o autor identifica como peculiaridade do processo histórico do planalto a necessidade de uma maior abertura às técnicas e os costumes indígenas, devido a uma insuficiência do meio. $\mathrm{O}$ foco na vida material dá-se por ser o âmbito no qual essa influência indígena seria mais acentuada. Dessa forma, essa esquematização em duas realidades, uma litorânea e outra interiorana, deve-se ao enfoque de Sérgio Buarque de Holanda em um conjunto concreto de problemas, para os quais tal contraposição é pertinente; ao mesmo tempo, reconhece o que há de comum em ambos os cenários. Nesse sentido, sua abordagem de um contexto especificamente paulista apresenta um viés analítico que a diferencia da realizada pela historiografia paulística, ainda que reafirme, para temas como a língua e a "rebeldia" política, algumas das interpretações oriundas desses autores, hoje já bastante discutíveis.

Partindo da análise de problemas concretos mais específicos, muitos trabalhos buscaram identificar os traços peculiares da colonização do planalto paulista, sem com isso construir imagens totalizantes e simplificadoras de uma São Paulo diferenciada das demais regiões. Um marco importante na identificação desses traços é o trabalho "Negros da terra", de John Manuel Monteiro, que reavaliou a inserção de São Paulo na América portuguesa ${ }^{141}$. Essa importante pesquisa revê criticamente a ideia de São Paulo como mero fornecedor de mão de obra para outras regiões da colônia - a leitura "de viés" de que fala Ilana Blaj -, analisando o desenvolvimento da agricultura no planalto, com produção de excedente para o

\footnotetext{
139 BLAJ, Ilana. "Mentalidade e Sociedade: revisitando a historiografia sobre São Paulo colonial", Revista de História da Universidade de São Paulo, n. 142-143, 1 sem. 2000, p. 255.

${ }^{140}$ HOLANDA, Sérgio Buarque de. Caminhos e fronteiras. $3^{\text {a }}$ ed. São Paulo: Companhia das Letras, 1994 [1956], p. 10.

${ }^{141}$ MONTEIRO, John Manuel. Negros da Terra: índios e bandeirantes nas origens de São Paulo. São Paulo: Companhia das Letras, 1994.
} 
mercado interno a partir do trabalho compulsório indígena. Monteiro considera a região como palco de um processo histórico específico:

os capítulos que se seguem procuram demonstrar que as principais estruturas da sociedade colonial na região surgiram de um processo histórico específico, no qual diversas e distintas sociedades indígenas ficaram subordinadas a uma estrutura elaborada visando controlar e explorar a mãode-obra indígena ${ }^{142}$.

Dessa forma, ainda que o paradigma da especificidade paulista, nos moldes mais generalizantes em que foi desenvolvido pela historiografia paulística ou pelas abordagens de cunho cepalino, seja hoje bastante questionado, os diversos elementos que compunham essa ideia de especificidade, como a liberdade política, o isolamento do planalto, a pobreza material e a "marginalidade" na economia colonial, continuam sendo extensamente estudados e debatidos. Dentre eles, a questão da liberdade política é ainda a mais polêmica, dado que se relaciona a discussões atuais sobre a natureza da estrutura política das monarquias quinhentistas e seiscentistas.

Como apontado anteriormente, a questão da liberdade política de São Paulo tem origem em diversas referências documentais que destacam a desobediência dos paulistas a determinações reais, relacionadas fundamentalmente à questão da mão de obra indígena no século XVII, que acabou por gerar aquilo que se convencionou chamar de Lenda Negra ${ }^{143}$. A interpretação historiográfica dessas narrativas seiscentistas dependeu, como não podia deixar de ser, das problemáticas contemporâneas relativas à identidade regional, o que era agravado, contudo, pelo caráter unilateral das fontes e pela grande influência dos textos jesuíticos. Os historiadores setecentistas Frei Gaspar da Madre de Deus e Pedro Taques de Almeida Paes Leme buscaram em suas obras combater a qualificação do paulista como rebelde, justificando-a pela animosidade jesuítica e apresentando a aristocracia de São Paulo como fiel vassala do rei. O desenvolvimento de uma interpretação de cunho federalista dessas referências à insubmissão dos paulistas virá à tona somente no interior de uma visão republicana do passado de São Paulo, que começou a ser esboçada a partir do final do século XIX. Durante o período imperial, praticamente inexistiu um discurso identitário paulista com base na História, com exceções pontuais como as obras do barão Homem de Melo e do ultracatólico Ricardo G. Daunt. Mesmo em um autor como Varnhagen, favorável aos métodos

\footnotetext{
${ }^{142}$ MONTEIRO, John Manuel. Negros da Terra: índios e bandeirantes nas origens de São Paulo. São Paulo: Companhia das Letras, 1994, pp. 8-9.

${ }^{143}$ SOUZA, Laura de Mello e. "Vícios, virtudes e sentimento regional: São Paulo, da Lenda Negra à Lenda Áurea", Revista de História da Universidade de São Paulo, n. 142-143, 1 sem. 2000, pp. 261-276.
} 
bandeirantes e crítico do viés indianista da historiografia desenvolvida no IHGB, predominava a defesa da fidelidade monárquica do paulista ${ }^{144}$.

A historiografia ligada ao IHGSP extraiu dessas referências um espírito de independência municipal que, como apontou a crítica mais recente, servia como fundamentação identitária para os conflitos políticos da República Velha e do Estado Novo. Afonso Taunay, por exemplo, trata do tema como "amor à autonomia, à liberdade", que teria ocasionado "a fama de insubmissos vassalos dos reis de Espanha e de Portugal" "145. Ainda que esse viés interpretativo apologético da historiografia paulística tenho sido largamente problematizado, como indicado anteriormente, a questão da autonomia política permanece objeto de controvérsias. Rafael Ruiz Gonzalez admite a situação de relativa autonomia política de São Paulo e analisa a inserção política da vila na estrutura do Império, durante a União Ibérica, identificando o papel que cumpria estrategicamente para a monarquia hispânica:

Todo o desenvolvimento da região, principalmente a partir do momento em que entrou em vigor o $2^{\circ}$ Regimento das minas, fez da vila um lugar bastante autônomo e independente, uma república, como os documentos exprimiam, aonde dificilmente chegava o peso e a força do poder central $^{146}$.

Para Ruiz Gonzalez, portanto, a situação de São Paulo era realmente bastante “peculiar”, devido à sua posição geográfica estratégica e da forte ligação com as regiões do Prata, Paraguai e altiplano boliviano, ocasionada pela maneira como a vila foi integrada aos planos da coroa de Castela ${ }^{147}$, propiciando uma convivência heterogênea na qual os "usos e costumes" tinham força de lei. Dessa forma, a autonomia política de São Paulo não se deve,

\footnotetext{
${ }^{144}$ Baseamo-nos aqui em FERRETTI, Danilo José Z. A construção da paulistanidade: identidade, historiografia e política em São Paulo (1856-1930). 2004. 391 f. Tese (Doutorado em História Social) - Faculdade de Filosofia, Letras e Ciências Humanas, Universidade de São Paulo, São Paulo, 2004. As exceções de Homem de Melo e Ricardo G. Daunt são tratadas no capítulo 1, pp. 27-37. Para Varnhagen e a fidelidade paulista, cf. pp. 90-101.

145 TAUNAY, Afonso de. São Paulo nos primeiros anos (1554-1601): ensaio de reconstituição social; São Paulo no Século XVI: história da vila piratiningana. Coordenação de Paula Porta. São Paulo: Paz e Terra, 2003 [1920, 1921], p. 86.

146 RUIZ GONZALEZ, Rafael. A vila de São Paulo durante a união das coroas: estratégias políticas e transformações jurídicas. 2002. 229 f. Tese (Doutorado em História Social) - Faculdade de Filosofia, Letras e Ciências Humanas, Universidade de São Paulo, São Paulo, 2002, p.7, itálico do autor. Cf. também: idem. "Colonos e jesuítas no planalto: A força dos usos e costumes na vila de São Paulo" In: CAMARGO, Ana Maria de A. (org.) São Paulo, uma longa história. São Paulo, CIEE, 2004, pp. 13-38.

147 “São Paulo, como resultado de sua situação geográfica, prevista por Portugal, integrou-se nos planos da Coroa de Castela de forma diferente de todas as outras cidades do Brasil, pois passou a compartilhar sua história com as populações do Paraguai, da Prata e do altiplano boliviano. É precisamente nessa história, peculiar a São Paulo, que reside a sua originalidade. Tal originalidade está marcada por aquilo que considero um dos pontos mais importantes deste trabalho: a força que os usos e costumes, como resultado de uma convivência heterogênea, tiveram na vila de São Paulo frente ao ordenamento legal", RUIZ GONZALEZ, "Colonos e jesuítas no planalto", op. cit., p. 32.
} 
para o autor, à incapacidade coercitiva da coroa ou às características morais dos paulistas, destemidos e insubmissos, como eram pintados pela historiografia paulística. Seguindo os caminhos teóricos abertos por António Manuel Hespanha, Ruiz Gonzalez entende essa relativa autonomia como admitida pela estrutura política do Império.

José Carlos Vilardaga, por sua vez, aponta a necessidade de considerar o espaço de disputas, conflitos e negociações que se estabelecia na relação entre a normatização metropolitana e a realidade política local, evitando contrapor essas duas instâncias de maneira demasiadamente esquemática. Afirma o autor:

O tema dos usos e costumes é bastante controverso na história de São Paulo. Há uma tendência a considerar uma suposta prevalência destes sobre as leis, numa clara bipolarização entre a norma metropolitana e a prática local. Esta leitura casou-se muito bem com as interpretações que reforçaram o caráter autônomo e rebelde dos "paulistas" em relação às autoridades reais. Longe de negar o papel importante dos usos e costumes, tanto em sua efetiva força legal, quanto retórica - aliás, bastante comum na época e utilizada por várias populações coloniais -, deve-se analisar a questão de maneira menos dicotômica $^{148}$.

Nesse sentido, a análise de Vilardaga considera a normatização legal proveniente do reino como uma das forças atuantes nas articulações políticas da vila, mobilizada eventualmente pelos próprios moradores tidos frequentemente como rebeldes ${ }^{149}$. O estudo da atuação do governador D. Francisco de Souza na vila é bastante representativo dessa perspectiva analítica, buscando por um lado evitar a dicotomia entre norma metropolitana e prática local, demonstrando a habilidosa articulação do governador entre essas instâncias, e, por outro lado, fugindo à contraposição entre o planalto rebelde e a costa, uma vez que episódios de resistência a normatizações do reino não foram exclusividade da região de Serra $\operatorname{Acima}^{150}$.

As questões, brevemente apresentadas, ligadas à autonomia política, isolamento e vida material no planalto, inserção econômica no contexto brasileiro e americano, bem como a utilização do paradigma da especificidade de São Paulo para explicá-las, estão focadas, como temos indicado, nos séculos XVII e XVIII. Para compreender como nossa temática e nosso período relacionam-se a essas discussões é preciso decompor essas camadas interpretativas acumuladas. O peso dessas discussões é tão grande que torna necessário

\footnotetext{
${ }^{148}$ VILARDAGA, José Carlos. São Paulo na órbita do Império dos Felipes: Conexões castelhanas de uma vila da América portuguesa durante a União Ibérica (1580-1640). 2010. 399 f. Tese (Doutorado em História Social) Faculdade de Filosofia, Letras e Ciências Humanas, Universidade de São Paulo, São Paulo, 2011, p. 167.

${ }^{149}$ Ibid., p. 331.

${ }^{150}$ A Análise sobre a atuação de D. Francisco é realizada no segundo capítulo (ibid., pp. 113-88).
} 
afirmar uma obviedade: a de que é preciso compreender o século XVI por ele mesmo, e não retrospectivamente.

Voltando-se mais especificamente para o nosso tema, a ideia de especificidade influenciou também a análise da vivência religiosa no planalto. À ideia de rebeldia (ou autonomia) em relação à administração real, associou-se a independência em relação à Igreja. Essa construção é largamente utilizada por José Gonçalves Salvador ${ }^{151}$. Ligando a ideia de rebeldia e desrespeito às leis dos homens e Deus, desenvolvida a partir do século XVII, ao nosso período encontra-se a figura emblemática de João Ramalho.

\subsection{O Caso de João Ramalho}

Dando sequência à análise do tratamento que a correspondência jesuíta dispensa aos colonos do planalto paulista, deteremo-nos neste tópico em um personagem específico, tido como patriarca dos paulistas, João Ramalho. Essa abordagem individualizada não se justifica por uma inclinação biográfica, mas por atender a duas problemáticas, uma documental e outra historiográfica. A primeira diz respeito ao fato de que, nas referências sobre a população de colonos do planalto presentes nas cartas jesuíticas, nenhum personagem recebeu tanto destaque individualmente quanto João Ramalho. A análise esmiuçada desse caso em particular permite estabelecer relações e comparações que tornam mais claras e concretas as questões que abordamos no tópico anterior. A segunda problemática refere-se à importância que o estudo da biografia de Ramalho teve na historiografia relativa a São Paulo colonial, tanto em aspectos metodológicos quanto na construção de certas imagens de um genérico paulista.

Na bibliografia que trata de João Ramalho, as cartas jesuíticas ocupam um papel de destaque, já que não há muitas referências documentais coetâneas a seu respeito, além de algumas indicações pontuais e fragmentárias. Há referências indiretas a seu testamento, poucas e curtas indicações nas atas da Câmara das vilas de Santo André da Borda do Campo e de São Paulo, bem como uma rápida e famosa passagem do viajante alemão Ulrich Schmidel,

\footnotetext{
${ }^{151}$ SALVADOR, José Gonçalves. Cristãos-Novos, jesuítas e inquisição: Aspectos de sua atuação nas capitanias do Sul, (1530-1680). São Paulo: Livraria Pioneira Editora, 1969, passim.
} 
que sequer o vira pessoalmente. Dessa forma, mesmo os historiadores que se contrapunham à visão jesuítica sobre o personagem tiveram que se valer das cartas em sua pesquisa.

Ainda que João Ramalho seja mais citado na correspondência do que outros colonos do planalto, o número dessas referências e as informações disponíveis são bastante reduzidas. Por isso, a utilização das passagens sobre o personagem na historiografia consistiu fundamentalmente na repetição de alguns curtos trechos, que acabaram por se tornar emblemáticos. Na coletânea do jesuíta Serafim Leite utilizada nesta pesquisa, Monumenta Brasiliae, é possível encontrar oito cartas que o $\operatorname{citam}^{152}$, quase sempre de forma rápida e, na maior parte das vezes, sem o nomear. Uma delas apenas faz referência a "huma povoação de João Ramalho", para situar o local no qual os jesuítas buscavam juntar a população indígena do planalto, a duas léguas da primeira.

Serafim Leite interpreta essas cartas, seguindo o caráter narrativo que impinge à sua coletânea, como testemunhos objetivos e complementares, que tornam possível apreender factualmente os diferentes momentos das relações entre Ramalho e seus filhos com os padres jesuítas. Nesse sentido, mesmo procurando resguardar o personagem, apontando uma reconciliação final deste com os jesuítas, aceita os termos do conflito e acusações tal como proposto nas cartas, revelando mais uma vez a voz institucional de sua historiografia.

Apesar das diversas hipóteses levantadas a respeito da biografia de João Ramalho, não há muitos dados objetivos ${ }^{153}$. É proveniente de Vouzela, freguesia da comarca de Viseu, província da Beira Alta, e parente do jesuíta Manuel de Paiva, que veio a conhecer no Brasil. Sua chegada à costa brasileira deu-se por volta de 1510, ainda que a data exata não seja conhecida. Há a hipótese, não confirmada, de que tenha sido degredado, mas cogita-se também que viera como marinheiro ou aventureiro. É apontado como o primeiro português a estabelecer-se no planalto da capitania de São Vicente, pouco tempo após aportar à costa, talvez por conta de um naufrágio. Entre os episódios mais conhecidos de sua trajetória estão o auxílio prestado à Martim Afonso de Souza em sua incursão ao planalto; sua relação marital com a índia Bartira ou Mb'ci, filha do cacique Tibiriçá e mãe de vários filhos seus; além de

\footnotetext{
152 São elas: $M B I$ (cartas 23, 28, 60, 69, 75) e $M B$ II (cartas 3, 22, 32); Serafim Leite identifica também como João Ramalho um "homem branco, que haa 60 anos que está nesta terra emtre este Gentio", citado pelo padre Baltasar Fernandes em carta de 1568, indicando tratar-se de uma opinião geral em relação a essa citação $(M B I V$, pp. 462-3). Essa identificação, verossímil mas não verificável, cumpre importante papel na interpretação que o historiador jesuíta dá aos conflitos de Ramalho com os missionários da Companhia, já que apresenta uma reconciliação do "miseravel velho" (ibidem) com os inacianos, por meio dos sacramentos. As demais cartas em que Ramalho é citado sem ser nomeado são mais facilmente identificáveis pelos episódios narrados.

${ }^{153}$ Para parte das informações, utilizamos aqui o resumo presente no verbete "João Ramalho" em AMARAL, Antonio Barreto do. Dicionário de História de São Paulo. São Paulo: Imprensa Oficial, 2006 [1903], pp. 518-9. Os demais dados baseiam-se na documentação das Atas da Câmara das vilas de Santo André da Borda do Campo e de São Paulo, bem como na correspondência jesuítica, analisados adiante.
} 
sua relação conturbada com os missionários jesuítas fundadores da casa de São Paulo de Piratininga. Ocupou os cargos de guarda-mor do campo e capitão-mor da vila de Santo André da Borda do Campo. Após a transferência desta para o sítio do Colégio de São Paulo, foi nomeado capitão de guerra da vila de São Paulo, em 1562, e, ao ser nomeado vereador dois anos depois, recusou o cargo alegando ter idade avançada.

Parte dessas informações chegou até nós por intermédio de uma carta do padre Manuel da Nóbrega, datada de agosto de 1553, e trazida à luz pelo jesuíta Serafim Leite em $1934^{154}$. Sua publicação acabou por esclarecer alguns fatos pontuais que haviam sido alvo de intenso debate nas décadas anteriores. Este documento tornou-se precioso para os estudiosos da vida de João Ramalho por destoar do tom conflituoso das demais referências epistolares, fornecendo um contraponto a algumas das condenações feitas pelos mesmos jesuítas em outros momentos. O objetivo expresso por Nóbrega é resolver a situação marital de Ramalho com a índia Bartira, não nomeada na passagem, uma vez que teria deixado mulher ainda viva em Portugal, quando de sua partida ${ }^{155}$. O momento de aproximação que esse documento compreende está relacionado ao benefício que o guarda-mor do campo poderia oferecer à manutenção da atividade jesuítica no planalto, como analisaremos mais adiante. Além das informações referentes à situação marital, vem também indicado com precisão seu local de origem, já que ao nome "Bouzela" acrescenta-se "tierra del Padre Maestre Simón”. Nóbrega data sua permanência no Brasil em "40 años y más”, o que localizaria sua chegada em 1513. No entanto, o trecho não aparenta buscar uma datação exata, podendo ser uma genérica aproximação.

Na historiografia do período colonial, as alusões a Ramalho estiveram basicamente relacionadas a alguns poucos episódios conhecidos, sem o interesse extensivo que viria a adquirir posteriormente. Os autores setecentistas Frei Gaspar da Madre de Deus e Pedro Taques de Almeida Paes Leme trataram-no positivamente, de acordo com as características de seus escritos de viés regional, voltados à valorização da aristocracia paulista. Em sua louvação da grandeza e fidelidade monárquica da elite da capitania, era necessário questionar as descrições negativas dos paulistas presentes nos textos jesuíticos ${ }^{156}$. Em relação ao caso específico de Ramalho, e de sua relação conturbada com os inacianos, afirmara Frei Gaspar:

Huns, e outros [jesuítas de São Paulo e Ramalhos de Santo André]

\footnotetext{
${ }^{154} M B I$, carta 75, pp. 521-7.

${ }_{155}^{155} M B$ I, pp. 524-5, para todas as citações do presente parágrafo.

156 FERRETTI, Danilo José Z. A construção da paulistanidade: identidade, historiografia e política em São Paulo (1856-1930). 2004. 391 f. Tese (Doutorado em História Social) - Faculdade de Filosofia, Letras e Ciências Humanas, Universidade de São Paulo, São Paulo, 2004, pp. 15-6.
} 
convidavaõ Indios, e Portuguezes, desejosos de attrahir grande numero de Povoadores, que se unissem a elles, e daquí nasceraõ as contendas, que tanto exagera o Chronista da Companhia do Brazil, lançando toda a culpa aos filhos de Joaõ Ramalho. Vasconcellos naõ explica, que as diligencias fôraõ reciprocas: cala as sollicitações de seus Socios: e pinta as dos Ramalhos por estylo, que os reputa sediciosos, ou rebeldes ao Estado quem lê a Chronica da sua Província ${ }^{157}$.

Como veremos adiante, a refutação da crônica seiscentista do jesuíta Simão de Vasconcelos seria fundamental para todos os defensores de João Ramalho. As diferenças entre a visão positiva e a negativa do andreense estiveram ligadas, principalmente, aos temas da identidade regional, da mão de obra indígena e da expansão bandeirante. Se para os memorialistas paulistas do século XVIII importava a valorização da atuação dos colonos do planalto, os debates desenvolvidos no ambiente intelectual da corte, no decorrer do século seguinte, iriam levar a uma condenação das práticas dos colonos em geral, notadamente dos bandeirantes, por parte da corrente dominante. O desenvolvimento de uma historiografia indianista no interior do IHGB, no período imperial, levou a uma contraposição maniqueísta entre a atuação dos missionários jesuítas e dos colonos leigos, na qual estes últimos representavam o polo negativo. Os aldeamentos jesuítas eram vistos por essa corrente, que possuía grande penetração na burocracia estatal, como modelo para a incorporação contemporânea das populações indígenas como mão de obra, desde que geridas pelo Estado monárquico $^{158}$. A historiografia indianista do IHGB teve em José Joaquim Machado d'Oliveira seu representante paulista que, em seu Quadro Histórico da Província de São Paulo, desenvolveu-a sob o recorte provincial. O interessante para nosso tema é a relativa benignidade com que Machado d'Oliveira trata João Ramalho, apesar da leitura predominantemente negativa da atuação dos colonos leigos. No lugar de acusá-lo de violento apresador de índios, afirma que estes "cuidavam em bem servil-o, menos pela condição de escravos seus, do que pela brandura com que os tratava"159.

A biografia de João Ramalho interessou muito mais intensamente aos pesquisadores da anteriormente citada historiografia paulística, ligada ao IHGSP, fundado em 1894. Este interesse inseria-se no objetivo desses autores em identificar e enaltecer os traços específicos da "raça paulista", da qual Ramalho seria o patriarca. Como destacamos no tópico anterior, a

\footnotetext{
${ }^{157}$ MADRE DE DEUS, Frei Gaspar da. Memórias para a história da Capitania de S. Vicente, hoje chamada de S. Paulo, do Estado do Brazil. Lisboa: Tipographia da Academia, 1797, p. 111.

${ }^{158}$ Para uma análise da historiografia indianista do IHGB, cf. FERRETTI, Danilo José Z. A construção da paulistanidade: identidade, historiografia e política em São Paulo (1856-1930). 2004. 391 f. Tese (Doutorado em História Social) - Faculdade de Filosofia, Letras e Ciências Humanas, Universidade de São Paulo, São Paulo, 2004, pp. 38-78.

159 OLIVEIRA, José Joaquim Machado d'. Quadro Histórico da Província de São Paulo. São Paulo: Typographia Imparcial de J. R. A. Marques, 1864, p. 28.
} 
construção de uma identidade paulista por essa corrente relacionava-se à situação econômica e às pretensões políticas da elite local no contexto da República Velha e do Estado Novo ${ }^{160}$. Uma avaliação positiva ou negativa da atuação de João Ramalho no planalto e de sua relação com índios e jesuítas tornava-se, dessa forma, tema capital para esses autores e refletia as divergências presentes nesse ambiente intelectual. No interior dessa produção historiográfica, um debate sobre o tema, promovido pelos membros do IHGSP em inícios do século XX, apresenta-nos o momento de maior polarização na discussão referente à biografia do andreense, além de argumentações e leituras documentais emblemáticas para o estudo de São Paulo colonial.

A discussão sobre João Ramalho no IHGSP teve início com a formação de uma comissão que buscava responder a uma indagação levantada no IHGB, pelo consócio José Luis Alves na reunião de três de março de 1899. Enquanto a proposta teve pouca repercussão no próprio IHGB, os paulistas acolheram o tema e deram início a um debate acalorado. A indagação em questão referia-se à veracidade do testamento de Ramalho, documento citado pelo monge beneditino Frei Gaspar da Madre de Deus no século XVIII e que não havia sido encontrado por nenhum outro historiador até então. Propôs José Luis Alves que se lançassem os historiadores à caça desse documento, do qual deveria haver "copia na Bibliotheca do mosteiro S. Bento de S. Paulo ou de Santos", além de procurar averiguar o caso com a documentação do tempo ${ }^{161}$.

A polêmica envolvendo o testamento de João Ramalho dizia respeito à controversa conclusão que dele tirava Frei Gaspar: o patriarca dos paulistas teria chegado ao Brasil por volta de 1490, antes da frota de Cabral e antes mesmo de Cristóvão Colombo chegar à América. Tal conclusão estava presente no manuscrito "Notícia dos anos em que se descobriu o Brasil e das entradas das religiões e suas fundações”, terminado em 1784 e publicado postumamente pelo IHGB em 1840. Essa afirmação valeu ao monge pesadas críticas de

\footnotetext{
${ }^{160}$ GLEZER, Raquel. Chão de terra e outros ensaios sobre São Paulo. São Paulo: Alameda, 2007, p. 47; BLAJ, Ilana. "Mentalidade e Sociedade: revisitando a historiografia sobre São Paulo colonial", Revista de História da Universidade de São Paulo, n. 142-143, 1 sem. 2000, p. 240: “A partir da historiografia 'paulística', vinculada ao Instituto Histórico e Geográfico de São Paulo, algumas imagens a respeito de São Paulo colonial foram sendo cristalizadas. Com efeito, tal historiografia tinha como construção implícita, a preocupação de justificar o poder de São Paulo no contexto de riqueza cafeicultora no âmbito da República Velha, o que pressupunha um relacionamento com os outros Estados e a luta pela hegemonia nacional. As imagens a partir daí resultantes edificam um paulista altivo, independente, arrojado e leal, cuja síntese seria o bandeirante".

161 FERRETTI, Danilo J.Z; CAPELATO, Maria H.R. "João Ramalho e as Origens da Nação: os paulistas na comemoração do IV centenário da descoberta do Brasil”, Revista Tempo, Dep. de História da UFF, v. 4, n. 8, dez/1999, pp. 2-3; RIHGB, tomo LXII, parte II, 1900, pp. 285-6.
} 
Candido Mendes de Almeida, que o acusava de criador de fábulas e falsificador de documentos ${ }^{162}$.

A discussão que se desenvolveu no IHGSP, a partir de 1902, não buscou reafirmar a primazia de João Ramalho sobre Cabral no descobrimento. De fato, nem os detratores do guarda-mor do campo, nem seus partidários, iriam questionar em momento algum que o primeiro a chegar ao Brasil havia sido Pedro Álvares Cabral. O debate concentrou-se em alguns aspectos da vida de Ramalho, buscando apresentá-lo ora como um herói modelo da paulistanidade, ora como um violento e analfabeto apresador de índios. Uma vez que a documentação sobre o andreense era escassa, como apontamos anteriormente - as atas da Câmara de Santo André permaneciam não transcritas -, era importante defender a credibilidade de Frei Gaspar, o primeiro a apresentá-lo de maneira positiva. Sendo assim, ainda que os defensores de Ramalho admitissem que o beneditino houvesse errado a data de chegada do futuro guarda-mor do campo, procuravam afastar a imagem de falseador da História que rondava Frei Gaspar, com vistas a não invalidar seu trabalho como um todo.

A comissão eleita pelo instituto em 1902 compunha-se de Teodoro Sampaio, Orville Derby, Antonio de Toledo Piza, João Mendes Junior e Manuel Pereira Guimarães. Buscava, inicialmente, emitir um parecer sobre o analfabetismo de João Ramalho ${ }^{163}$. Chegou à conclusão de que ele era analfabeto e, provavelmente, judeu, conclusão que partiu de uma análise grafológica das assinaturas de Ramalho presentes no que restavam das atas da Câmara de Santo André da Borda do Campo. Subscreveram o parecer, que teve Teodoro Sampaio como relator, todos os membros da comissão, com exceção de Pereira Guimarães, que publicou parecer em separado nas páginas de O Estado de São Paulo de 20 de julho de $1902^{164}$.

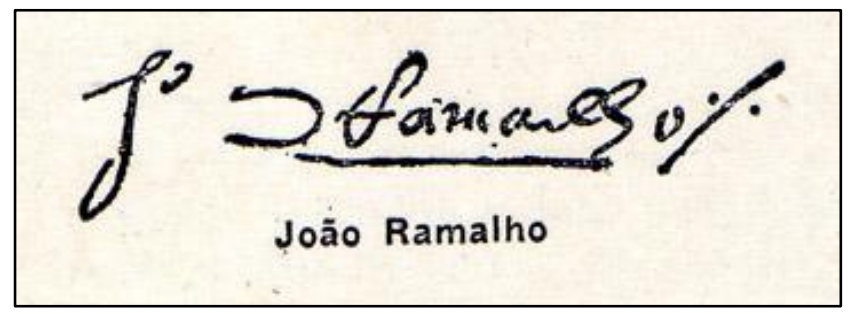

Figura 1 - Assinatura de João Ramalho presente em ata da Câmara de Santo André.

\footnotetext{
${ }^{162}$ RIHGB, tomo XL, parte II, 1877 , p. 277 et seq.

163 TAUNAY, Affonso de E. João Ramalho e Santo André da Borda do Campo. São Paulo: Publicação comemorativa do Quarto Centenário da Fundação de Santo André da Borda do Campo, 1953, p. 95.

${ }^{164}$ FERRETTI, Danilo J.Z; CAPELATO, Maria H. R. "João Ramalho e as Origens da Nação: os paulistas na comemoração do IV centenário da descoberta do Brasil”, Revista Tempo, Dep. de História da UFF, v. 4, n. 8, dez/1999, p. 11.
} 
Em relação ao analfabetismo do "patriarca dos paulistas", já apontado anteriormente por Varnhagen ${ }^{165}$, a comissão justificava sua posição afirmando que ele não sabia escrever seu próprio nome, uma vez que a grafia diferia muito entre as assinaturas encontradas, o que sugeriria terem sido feitas por pessoas diferentes, que completavam o sinal por Ramalho grafado (o "c" invertido e, segundo alguns, em forma de ferradura) ${ }^{166}$. Argumentaram os ramalhistas a favor da improbabilidade do analfabetismo, ou de sua pouca relevância ${ }^{167}$.

Para o nosso tema - a vivência religiosa dos colonos - é de importância maior a outra conclusão que se tirou da controversa assinatura. $\mathrm{O}$ "c" invertido encontrado nas assinaturas de Ramalho levou a comissão do IHGSP a identificá-lo como judeu, visto que em vez da cruz, presente nas demais assinaturas, encontraram o referido sinal, reconhecido por eles como o kàf - letra simbólica do alfabeto hebraico. O sinal seria também associado pelos defensores do andreense a um símbolo maçônico, elmo de cavaleiro (sinal de nobreza), rabisco arbitrário ou símbolo do cargo que ocupava ${ }^{168}$. Eram sustentadas essas afirmações por conjecturas as mais diversas, que não contavam com outra base documental direta senão a própria assinatura ${ }^{169}$. Argumentaram também os ramalhistas que, caso se confirmasse o judaísmo do "patriarca", isso em nada afetaria sua imagem positiva ${ }^{170}$, afirmação que, ao se fazer necessária, acaba por revelar o caráter negativo que a classificação de judeu poderia adquirir na construção de um herói da nacionalidade naquele momento.

Também relacionada ao aspecto religioso foi a reafirmação, pelo parecer da comissão, da avaliação que do andreense fez o jesuíta Simão de Vasconcelos, em sua Chronica da Companhia de Jesu do Estado do Brasil (1663), na qual descrevia João Ramalho como "homem por graves crimes infame, e actualmente escommungado" ${ }^{171}$, frase que seria repetida em praticamente todos os textos do debate, e sempre refutada pelos ramalhistas. Outra passagem da crônica que seria retomada com frequência é a que apresenta o alcaide-

\footnotetext{
165 GURGEL, Leoncio do Amaral. “João Ramalho perante a História”, RIHGSP, vol. IX, 1904, p. 448.

${ }^{166}$ FERRETTI, Danilo J.Z; CAPELATO, Maria H. R. "João Ramalho e as Origens da Nação: os paulistas na comemoração do IV centenário da descoberta do Brasil", Revista Tempo, Dep. de História da UFF, v. 4, n. 8, dez/1999, p. 10; TAUNAY, Affonso de E. João Ramalho e Santo André da Borda do Campo. São Paulo: Publicação comemorativa do Quarto Centenário da Fundação de Santo André da Borda do Campo, 1953, p. 95.

${ }^{167}$ GURGEL, loc. cit.

168 RIBEIRO, J. C. Gomes. "João Ramalho: sua fé e nobreza", RIHGSP, vol. VII, 1902, p. 424.

169 Teodoro Sampaio afirma ter até mesmo recorrido a especialistas estrangeiros ("orientalistas competentes") no sentido de confirmar a identificação do sinal com o káf hebraico ("A propósito de João Ramalho", RIHGSP, vol. VII, p. 299). Horacio de Carvalho dedica mais de 60 páginas unicamente para confirmar essa hipótese sobre o "c" invertido ("A assignatura symbolica de João Ramalho interpretada como si fosse o káf hebraico", ibid., pp. 303-368).

${ }^{170}$ GURGEL, Leoncio do Amaral. “João Ramalho perante a História”, RIHGSP, vol IX, 1904, pp. 445-6.

171 VASCONCELOS, Simão de. Chronica da Companhia de Jesu do Estado do Brasil, vol. I. 2a ed. Lisboa: 1865 [1663], p. 47.
} 
mor como "homem rico da terra, mas infame nos vicios, amancebado publico por quasi quarenta annos"172.

No decorrer das argumentações pró-Ramalho, a reabilitação moral do personagem acaba por assumir maior destaque do que a negação de seu judaísmo e analfabetismo. Era importante para aqueles que procuravam apontar no "patriarca" as qualidades de toda a "estirpe paulista" que se lhe seguiu, combater a visão negativa que prevaleceu sobre ele durante todo século XIX e era então reafirmada pela comissão do IHGSP.

Em tal combate, além de desacreditar os testemunhos contrários, conjecturavam o quanto possível com as escassas informações existentes. Quando, em 1904, Washington Luis finalmente encontra uma referência documental mais extensa e detalhada ao polêmico testamento nos papéis de José Bonifácio, publicada na revista do IHGSP ${ }^{173}$, presta enorme contribuição ao esforço de validar as informações presentes nas Memórias de Frei Gaspar ${ }^{174}$. No entanto, quando do início do debate, em 1902, nada se podia afirmar de muito certo sobre o conteúdo do testamento. Dessa forma, a única documentação coeva que os ramalhistas tinham à sua disposição para reabilitar o "patriarca" eram as cartas jesuíticas, ainda espalhadas em diversas publicações e sem a organização sistemática que lhes daria Serafim Leite a partir da década de 1950.

De maneira geral, a leitura que esses autores fizeram das cartas jesuíticas restringiuse às passagens em que se falava diretamente de João Ramalho. Seguindo o procedimento com o qual abordavam toda a documentação, os partidários do alcaide-mor de Santo André desqualificavam as descrições negativas que dele faziam os inacianos, atribuindo-as à inimizade que para com ele nutriam. Dessa maneira, segundo Campos Andrade ${ }^{175}$, a figura de Ramalho estava envolta em nebulosidade "creada pelas informações transmittidas pelos socios da Companhia de Jesus, sua tradicional inimiga". Apesar disso, consideravam possível extrair das cartas, nas entrelinhas dos ataques jesuíticos, informações objetivas que julgavam capazes de justificar a construção positiva que faziam do personagem.

Outro esforço empreendido pelos partidários de Ramalho foi o de afastar a narração presente nas cartas jesuíticas do século XVI daquela presente na crônica posterior de Vasconcelos. Afirma J. C. Gomes Ribeiro:

\footnotetext{
172 VASCONCELOS, Simão de. Chronica da Companhia de Jesu do Estado do Brasil, vol. I. $2^{\text {a }}$ ed. Lisboa: 1865 [1663], p. 75.

173 “O testamento de João Ramalho", RIHGSP, vol. IX, 1904, pp. 563-569.

${ }^{174}$ Resolveu-se também a questão da data de chegada de João Ramalho, atribuindo-se o cálculo errôneo de Frei Gaspar a um equívoco de tradução (ibid., p. 567).

${ }^{175}$ ANDRADE, Francisco de Campos. "João Ramalho: contribuição para sua rehabilitação", RIHGSP, vol. VII, 1902, p. 370.
} 
Como explicar-se ainda não constarem tão tremendas accusações a Ramalho, nominalmente, de nenhuma das cartas dos padres Nóbrega, Anchieta, Leonardo Nunes, Balthazar Fernandes, e outros, abrangendo o periodo de 1549 a $1568[\ldots]^{176}$.

Não faz Gomes Ribeiro, contudo, uma análise mais pormenorizada do conteúdo dessas cartas. Mais detido é o esforço de Francisco de Campos Andrade, que contrapõe à crônica do padre Simão uma carta de José de Anchieta de 1554, buscando mostrar que, apesar de narrarem os mesmos acontecimentos e, à primeira vista, concordarem, apresentavam diferenças sutis, que demonstrariam o quanto foi desfigurado o relato mais fiel de Anchieta ${ }^{177}$. Em suas palavras:

[...] si, para o chronista, os mamelucos de Santo André, os filhos de Ramalho, são 'peiores fructos de uma arvore ruim, uma caterva de filhos de má casta, mamelucos illegitimos e desalmados', para Anchieta, que os conhecia de visu, eram 'CHRISTÃOS nascidos de pae portuguez e de mãe brasilica'. Si, aquelle dá a entender vagamente, insinua aéreamente que o portuguez abusava da polygamia, e os filhos eram pagãos, este, mais digno de credito, mais authentico, diz que os filhos eram christãos, nascidos de uma só mã $e^{178}$.

Essa argumentação não resistiria a uma leitura sistemática das cartas de Anchieta, ou mesmo a uma análise mais detida dessa única carta, visto que mais adiante é também insinuado o "abuso da poligamia" que o autor diz ser omitido pelo jesuíta, mesmo afirmandose serem os filhos de uma única mãe, apresentada como sua concubina ${ }^{179}$. O consócio do IHGSP consultou o que na verdade tratava-se de um resumo de duas cartas de Anchieta ${ }^{180}$, que foram publicadas na íntegra somente na coletânea de Serafim Leite ${ }^{181}$. O que vemos nas duas cartas (uma de setembro de 1554 e outra de março de 1555) é uma descrição de João Ramalho e seus filhos bastante negativa, muito diferente de quanto apresenta Campos Andrade em sua contraposição. De fato, Anchieta identifica-os como "cristãos nascidos de pai português [J. Ramalho] e mãe brasílica”, mas ainda no mesmo parágrafo apresenta-os como "exemplo duma nefanda e abominável depravação" para os indígenas ${ }^{182}$. É ainda nessa carta que se descreve a adoção dos "costumes dos gentios" por parte dos filhos do andreense:

\footnotetext{
${ }^{176}$ RIBEIRO, J. C. Gomes. “João Ramalho: sua fé e nobreza”, RIHGSP, vol. VII, 1902, p. 425.

177 ANDRADE, Francisco de Campos. "João Ramalho: contribuição para sua rehabilitação", RIHGSP, vol. VII, 1902, pp. 389-90.

${ }^{178}$ Ibid., p. 390, grifos do autor.

${ }^{179} M B$ II, pp. 115-6.

${ }^{180}$ Campos Andrade apresenta como referência a obra III Centenario do veneravel Joseph de Anchieta. Paris: Aillaud \& C, 1900.

${ }^{181} M B$ II, cartas 22 e 32

${ }^{182} M B$ II, pp. 114-5.
} 
[...] tendo um destes cristãos trazido um cativo, entregou a um irmão dele para o matar. E matou-o de facto com a maior crueldade, tingindo as próprias pernas de vermelho e tomando o nome de quem matara em sinal de honra, como é costume dos gentios [...]. E são cristãos, nascidos de pai cristão, que sendo espinho não pode produzir uvas ${ }^{183}$.

Tampouco se considerou o uso da palavra "cristão" nessa documentação, que não significaria, como se vê no trecho citado, uma adjetivação da fé e de práticas religiosas e morais, como apresenta o autor. A palavra "cristão" era indistintamente utilizada pelos missivistas como contraposição a gentio, referindo-se genericamente aos portugueses (ou outros europeus, se fosse o caso) sem qualquer valor descritivo que não o de indicar objetivamente a origem; poderia também, como parece ser o caso nesse trecho, fazer referência a uma mais ampla identidade civilizacional europeia, indissociável do âmbito religioso, mas não resumida à aceitação formalizada da fé e ao sacramento do Batismo; poderia ainda relacionar-se ao sentido religioso estrito e adjetivar também os indígenas, quando se contrapunham os batizados e os não batizados. Para compreender essa polissemia, Campos Andrade teria que partir de uma leitura mais sistemática dessa documentação.

O exemplo que acabamos de apresentar é bastante representativo da metodologia historiográfica utilizada em todo o debate desenvolvido no IHGSP. A leitura documental que se fazia era aleatória, retirando fragmentariamente as informações desejadas e desconsiderando a totalidade da carta e sua relação contextual e intertextual, completando as lacunas temerariamente com especulações diversas. Veja-se, como um dos muitos exemplos, nesse mesmo texto de Francisco de Campos Andrade, a conjectura que faz o autor para refutar as afirmações de uma carta do padre Balthazar Fernandes de 22 de abril de 1568:

Si Ramalho não fosse catholico, não só seu filho, que neste caso teria sido educado no odio ao padre, qualquer que elle fosse, não se teria lembrado de caminhar uma legua sómente para ir dizer aos padres que seu pae morrera, como o respeito ao modo de sentir do seu progenitor o teria impedido ${ }^{184}$.

No entanto, ao lado desse tipo de utilização documental da correspondência jesuítica, há também a tentativa, ainda que tímida, de retirar informações mais amplas, referentes à vida no planalto. O mesmo Campos Andrade utiliza outra carta de Anchieta, de 1556, não para tirar informações sobre o "patriarca dos paulistas", mas sobre problemáticas envolvendo a evangelização, como a tendência ao nomadismo dos indígenas, o reconhecimento da

\footnotetext{
${ }^{183} M B I I$, p. 115.

184 ANDRADE, Francisco de Campos. "João Ramalho: contribuição para sua rehabilitação", RIHGSP, vol. VII, 1902, p. 375.
} 
necessidade do uso da força pelos inacianos etc. ${ }^{185}$ Nesse ponto, parece adiantar a tendência, predominante na segunda metade do século XX, de interpretação dessa documentação a partir de uma leitura que busca identificar não as informações factuais, mas aquelas relativas à organização social, política e material da vida no planalto. Em outro ponto, contudo, podemos considerar que os debatedores do IHGSP foram mais atentos ao caráter subjetivo das cartas do que muitos pesquisadores que se lhes sucederam. Ainda que aqueles, como Campos Andrade, favoráveis a João Ramalho, buscassem apenas invalidar as acusações dos membros da Companhia, reforçaram a importância em se avaliar as narrativas epistolares em função do conflito entre jesuítas e colonos pelo controle da população indígena, como já indicara Frei Gaspar. Premissa que não encontramos em muitas das pesquisas mais recentes, como temos apontado. Por outro lado, acabavam por subdimensionar o que havia de comum nesses dois âmbitos da presença europeia no planalto.

Ao destacarmos, em relação ao debate, a predominância de argumentações quase unicamente especulativas e uma interpretação dos documentos que parece a um historiador de hoje excessivamente arbitrária, não temos o objetivo de contrapor as características da historiografia metódica, própria da vertente paulística, às correntes atuais. De fato, os resultados do debate foram inconclusivos até mesmo quando avaliados a partir dos critérios dessa corrente, como apontaria muitos anos depois seu maior representante, Afonso de Escragnolle Taunay. Para ele, seguidor da ideia de que a História se faz com documentos, e somente com documentos, esse esforço argumentativo carecia de maior base documental, girando quase sempre "em torno do que havia de impresso da obra de Frei Gaspar da Madre de Deus, de Pedro Taques, de Simão de Vasconcelos e mais alguns autores a se repetirem”; e, dessa forma,"nada de novo se conquistou para o esclarecimento da biografia do patriarca do Planalto" "186. Ele próprio, contudo, em sua síntese essencialmente positiva sobre João Ramalho $^{187}$ - já se valendo das transcrições das atas da Câmara de Santo André da Borda do

\footnotetext{
185 ANDRADE, Francisco de Campos. "João Ramalho: contribuição para sua rehabilitação", RIHGSP, vol. VII, 1902, pp. 391-3.

186 TAUNAY, Afonso de E. João Ramalho e Santo André da Borda do Campo. São Paulo: Publicação comemorativa do Quarto Centenário da Fundação de Santo André da Borda do Campo, 1953, pp. 94-5. Taunay classificou esse debate de "indeterminado e ocioso [...] que muito mais util teria sido se o tempo nele dispendido houvesse sido empregado em pesquizas no próprio arquivo municipal paulistano" (ibidem).

187 A citada obra João Ramalho e Santo André da Borda do Campo, de 1953, apresenta uma síntese de toda a discussão até então sobre o "patriarca dos paulistas"; representa um momento em que a figura de Ramalho estava já reabilitada e identificada com o bandeirante. Essa fase da historiografia identitária paulista, com a exaltação do bandeirante e sua mobilização para uso político, tem seu auge nas décadas de 1920 e 1930 , com os trabalhos de Taunay, Alfredo Ellis Jr. e Oliveira Vianna. Cf. FERRETTI, Danilo J. Z.; CAPELATO, Maria H. R. "João Ramalho e as Origens da Nação: os paulistas na comemoração do IV centenário da descoberta do Brasil”, Revista Tempo, Dep. de História da UFF, v. 4, n. 8, dez/1999, p. 13.
} 
Campo - realizou uma leitura da documentação jesuítica não muito distante daquela utilizada na contenda.

O debate acerca de João Ramalho no IHGSP sintetiza de maneira esquemática os posicionamentos antagônicos que marcaram por muito tempo a apreciação das cartas jesuíticas pela historiografia de São Paulo colonial, e que ainda ecoam nas discussões atuais sobre a especificidade do planalto paulista. A predominância, no parecer da comissão designada pelo IHGSP, da visão negativa de Ramalho, em um momento no qual muitos esforços eram despendidos para a construção de uma imagem positiva dos primeiros paulistas, reflete o conflito entre jesuítas e colonos e a maneira como as cartas o documentaram, uma vez que os membros da comissão estavam envolvidos no desenvolvimento de uma política indígena que tinha por base justamente os antigos aldeamentos jesuítas, atacados pelos $\operatorname{colonos}^{188}$. Na historiografia paulística desenvolvida nas décadas que se seguiram ao debate, predominou a visão positiva de João Ramalho como patriarca da estirpe paulista e iniciador do empreendimento bandeirante, da qual o trabalho mais representativo seria a síntese de Afonso Taunay, João Ramalho e Santo André da Borda do Campo, anteriormente citada. Até mesmo o jesuíta Serafim Leite, entusiasta do empreendimento missionário, buscou amenizar o conflito e contribuir para a reabilitação do antigo desafeto de Anchieta e Leonardo Nunes, afastando a hipótese de que fosse judeu e reservando-lhe um final pio. Publicou a sobredita carta inédita de Nóbrega de 1553, que considerava indicativa de uma aproximação entre as partes, e abordou em sua História da Companhia de Jesus no Brasil as esparsas referências epistolográficas a Ramalho como a narrativa acidentada desse entendimento até um final amigável, que estaria subentendido no testamento ${ }^{189}$.

A historiografia sucessiva não se interessou muito pela figura do patriarca dos paulistas, sintoma de uma mudança de orientações que colocaria os grandes personagens em um plano secundário. Sem muito espaço nas discussões historiográficas, a biografia de João Ramalho cumpriu, por outro lado, importante papel em um âmbito diverso, aquele da construção da memória paulista, na qual Afonso Taunay também teve papel de destaque

\footnotetext{
${ }^{188}$ Afirmam Ferretti e Capelato: "Assim, vemos que, no seu presente, os historiadores membros da comissão do IHGSP que desqualifica a figura de João Ramalho, defendiam um modelo de incorporação do indígena baseado na experiência jesuítica" (FERRETTI, Danilo J. Z.; CAPELATO, Maria H. R. "João Ramalho e as Origens da Nação: os paulistas na comemoração do IV centenário da descoberta do Brasil", Revista Tempo, Dep. de História da UFF, v. 4, n. 8, dez/1999, p. 11). Em relação ao debate entre os intelectuais paulistas sobre a incorporação do indígena, conferir o capítulo 9, "Tupis, Tapuias e a História de São Paulo", em MONTEIRO, John Manuel. Tupis, Tapuias e historiadores: Estudos de História indígena e do indigenismo. 2001. 233 f. Tese (Livre Docência em Etnologia) - Instituto de Filosofia e Ciências Humanas, Unicamp, Campinas, 2001, pp. 180-193.

${ }^{189}$ LEITE, Serafim, S. J. História da Companhia de Jesus no Brasil, tomo II. Lisboa: Livraria Portugália; Rio de Janeiro: Civilização Brasileira, 1938, pp. 378-84.
} 
enquanto diretor do Museu do Ipiranga entre os anos de 1917 e 1939. Mesmo que o personagem não interessasse mais aos historiadores em sua individualidade, as mesmas passagens das cartas continuaram a ser citadas na historiografia mais recente, com a intenção de descrever não um único personagem, mas o paulista em sentido mais genérico. Uma passagem de Anchieta, em especial, tornou-se emblemática e foi citada repetidamente, sempre recortada do restante da carta. O trecho em questão é a fala do mameluco (filho de Ramalho) que, ao ser advertido "de que tivesse cuidado com a Santa Inquisição por seguir alguns costumes gentílicos, respondeu que vararia com flechas duas inquisições"190. A passagem fazia parte de uma carta enviada por José de Anchieta a Inácio de Loyola em setembro de 1554, a mesma carta que Francisco de Campos Andrade utilizou em 1902 para questionar a crônica de Simão de Vasconcelos, como mostramos anteriormente.

O sentido que se buscou dar à citação foi o de apontar o pouco apreço dos mamelucos de São Paulo em relação ao Santo Ofício. Não é de pouca importância, no entanto, que essa antipatia apareça no trecho em um formato de insubmissão. Como veremos, esse teor adquire maior significado quando consideramos o texto como um todo. Podemos ver essa utilização do trecho em uma passagem de José Gonçalves Salvador:

Cêrca de uma década antes, José de Anchieta escreveu uma carta da Capitania de São Vicente, ou seja, em 1554, na qual conta que ao exortar certo mamaluco por seguir práticas gentílicas, ameaçando-o com a Inquisição "respondeu que vararia com flechas duas inquisições". Sinal de que pouco se importavam os mamalucos com o Santo Ofício, ainda mal conhecido ${ }^{191}$.

Na maneira como Salvador construiu sua citação, fica a impressão de que a advertência teria partido do próprio Anchieta, quando, na carta, utiliza-se um impessoal "advertindo-se de que tivesse cuidado" $" 192$, que não permite conclusões muito peremptórias. Pela tradução portuguesa utilizada, baseada no texto remanescente em latim ${ }^{193}$, fica difícil até mesmo concluir se o autor da carta teria presenciado a enunciação da frase. Na proposta de leitura que adotamos, no entanto, trata-se de um problema menor, já que a veracidade da informação não se dá em termos de relato fiel de um acontecimento. A fala do paulista advertido é retirada de seu contexto narrativo, fato que, como veremos, tem importantes

\footnotetext{
${ }^{190} M B I I$, p. 115.

${ }^{191}$ SALVADOR, José Gonçalves. Cristãos-Novos, jesuítas e inquisição: Aspectos de sua atuação nas capitanias do Sul, (1530-1680). São Paulo: Livraria Pioneira Editora, 1969, p. 84. Alcântara Machado houvera já apresentado uma utilização semelhante do trecho em questão (Vida e morte do bandeirante. São Paulo: Imprensa Oficial do Estado de São Paulo, 2006 [1929], pp. 203-4).

${ }^{192}$ MB II, p. 115, itálico nosso.

${ }^{193}$ O documento consultado por Serafim Leite está em latim, mas não é possível definir se é uma cópia traduzida e em que língua foi originalmente escrita (MB II, p. 84).
} 
implicações. Salvador utiliza a carta como um registro objetivo do diálogo, já que se permite concluir qual seria a opinião do mameluco a partir da narrativa.

Por um lado, uma antipatia dos habitantes do planalto pelo Santo Ofício é fato verossímil, como o seria para todas as regiões ibéricas ou americanas, ainda que seja difícil avaliar o quanto seria conhecido pelos filhos de João Ramalho. Laura de Mello e Souza, no seu fundamental trabalho sobre as práticas religiosas na colônia, retoma a citação de Gonçalves Salvador com o mesmo fim: apontar a ira ibérica e americana contra a Inquisição ${ }^{194}$. Ainda que não consideremos essa citação de Anchieta o caminho mais seguro para sustentar empiricamente essa argumentação, a referência integra um conjunto de diversa natureza, relacionado a distintas localidades do mundo ibérico e americano.

O descaso do mameluco é narrado por Anchieta, por outro lado, como parte de uma crítica a João Ramalho e seus filhos, que são tratados durante todo o relato separadamente dos demais habitantes de Santo André; e, no contexto da crítica, o Santo Ofício torna-se menos importante do que a maneira rebelde com que o mameluco refere-se à autoridade. Na frase que antecede a série de críticas, o padre apresenta separadamente o alvo: "De facto, alguns cristãos nascidos de pai português e mãe brasílica, que estão apartados de nós 9 milhas numa povoação de Portugueses" ${ }^{\prime 195}$. Deixando de lado momentaneamente a questão da aversão ao Santo Ofício, não são, portanto, os mamelucos em geral que Anchieta busca apresentar como desobedientes e insubmissos, mas os mamelucos filhos de Ramalho. Em uma carta no ano seguinte, também para Loyola, Anchieta retoma o assunto e diz, ainda sobre Ramalho e os filhos, que "Se pudessem até os próprios portugueses afastariam da fé cristã"196. Entretanto, se considerarmos a imagem, tradicional na historiografia, do paulista "independente das autoridades da marinha" ${ }^{197}$, podemos observar as consequências que o uso fragmentário dessa citação pode trazer. Como vimos no tópico precedente, a qualificação do paulista, em um sentido generalizante, como rebelde, está fundamentalmente ligada ao século XVII. Sob o peso desta imagem, a crítica que Anchieta dirige a um grupo bem determinado de colonos do planalto pode ser lida como análoga às críticas dos jesuítas seiscentistas ao paulista. De fato,

\footnotetext{
194 SOUZA, Laura de Mello e. O diabo e a Terra de Santa Cruz: feitiçaria e religiosidade popular no Brasil colonial. São Paulo: Companhia das Letras, 1986, p. 101.

${ }^{195} M B I I$, p. 114.

${ }^{196} M B$ II, p. 195.

197 ABREU, Capistrano de. Capítulos de História Colonial (1500-1800). Rio de Janeiro: M. Orosco \& C., 1907, p. 99 .
} 
observamos em trabalhos recentes a utilização dessa famosa passagem para reforçar a ideia do paulista rebelde ${ }^{198}$.

A célebre ameaça do mameluco armado ao Santo Ofício pode ser interpretada diversamente se a tomarmos na totalidade da carta, considerando os conflitos concretos que a produziram e sua estrutura formal específica, fruto da tradição da ars dictaminis e seus desdobramentos modernos.

Resumidamente, temos como conteúdo da carta em questão uma primeira descrição da localização das residências e irmãos em cada capitania, de acordo com as instruções recebidas do padre Polanco por comissão de Loyola ${ }^{199}$. Descrição na qual se intercalam informações sobre acontecimentos relevantes em cada localidade (chegadas e partidas de irmãos, trabalhos desenvolvidos com indígenas e portugueses etc.). Em seguida, apresentamse os fatos concernentes à aldeia de Piratininga, que incluem a mudança efetuada da costa para esse sertão, os trabalhos realizados nessa aldeia com a população indígena, localização geográfica, mantimentos etc. Segue-se uma descrição dos costumes dos portugueses da povoação de João Ramalho, uma descrição dos índios Carijó e outras informações sobre chegadas e partidas de irmãos.

Trata-se de uma carta edificante, como eram aquelas chamadas quadrimestrais ${ }^{200}$. No caso, refere-se ao quadrimestre até junho de 1554. As informações referentes à localização dos colégios e irmãos seguiam as instruções de confecção das cartas edificantes ${ }^{201}$, sendo esta o exemplo maior de adequação ao modelo proposto para essa modalidade de carta. Isso significa que as informações nela presentes são aquelas permitidas a pessoas de fora da ordem e que seguia, preferencialmente, a estrutura formal da ars dictaminis medieval, não aquela pessoal e amigável do sermo, destinada às hijuelas ${ }^{202}$. Também significa que seu conteúdo estava principalmente voltado para objetivos devocionais e de "propaganda" das missões, lembrando, porém, que esse tipo de divisão não era intransponível.

De acordo com a proposta da ars dictaminis, reinterpretada pela Companhia de Jesus, temos em nossa carta a salutatio, que apresenta a fórmula piedosa "A paz de Nosso

\footnotetext{
${ }^{198}$ Cf., por exemplo, o capítulo "O comportamento do paulista em relação à Inquisição”, In: BOGACIOVAS, Marcelo M. A. Tribulações do Povo de Israel na São Paulo colonial. 2006. 270 f. Dissertação (Mestrado em História Social) - Faculdade de Filosofia, Letras e Ciências Humanas, Universidade de São Paulo, São Paulo, 2006, pp. 151-4. 
Senhor Jesus Cristo seja sempre em nossos corações. Amen"203. Assim como Pécora ${ }^{204}$ identifica nas cartas de Nóbrega, utiliza-se aqui o "nós", que, em lugar de reforçar a hierarquia (no caso, Loyola está hierarquicamente acima de Anchieta), reafirma a união entre os membros da Companhia. A captatio benevolentiae, que inclui, entre os jesuítas, fórmulas de humildade, obediência e desejo de martírio, assim como a petitio, referente geralmente a necessidade de mais missionários, não se apresentam nesse escrito de Anchieta como divisões físicas do texto, mas aparecem diluídas no decorrer da narratio.

$\mathrm{Na}$ narratio, ainda segundo Pécora, trata-se de "construir um relato do ocorrido à pessoa ausente" ${ }^{205}$. Observamos, em nosso exemplo selecionado, o procedimento análogo àquele observado em Nóbrega, de apresentar um estado de coisas a partir de cenas exemplares:

A narração é sobretudo uma descrição ou composição de um quadro temático em que os acontecimentos selecionados atuam no conjunto como exemplos de situações repetidas, que referem menos ocorrências verdadeiramente únicas do que cenas exemplares, típicas, capazes de evidenciar determinada prática ou costume longamente estabelecido ${ }^{206}$.

Considerando o conjunto temático e formal da carta, podemos analisar mais detidamente a descrição dos maus costumes dos paulistas, que mais nos interessa, e entender como se enquadra neste conjunto. Logo após descrever a dificuldade da evangelização com "estes, entre os quais trabalhamos [indígenas de Piratininga]" 207 , por recalcitrarem devido à falta de sujeição a rei ou chefe e não se apartarem da antropofagia e do concubinato, reafirma a necessidade de mitigar "todo o direito positivo" e "outras leis da Santa Madre Igreja", caso contrário "não há dúvida que não quereriam dispor-se a seguir a fé cristã"208. Ao final da passagem, Anchieta conclui afirmando que o fato de serem bárbaros e indômitos "não é tanto de admirar como a tremenda malícia dos próprios cristãos, nos quais encontram não só exemplo de vida mas também favor e auxílio para praticarem más acções" ${ }^{\text {,209 }}$. Seguem-se a essa afirmação genérica os três parágrafos que consistem em apresentar João Ramalho e seus filhos como exemplares dessa má conduta.

\footnotetext{
${ }^{203} M B$ II, p. 101.

${ }^{204}$ PÉCORA, Alcir. “Arte das Cartas jesuíticas do Brasil”. In: ENCONTRO INTERNACIONAL NÓBREGAANCHIETA, 1999, São Paulo. VOZ LUSÍADA. Anais do Encontro Internacional Nóbrega-Anchieta. São Paulo: Green Forest do Brasil, 1999, v. 1, p. 46.

205 Ibid., p. 50 et seq.

${ }^{206}$ Ibid., p. 50.

${ }^{207} M B$ II, p. 113.

${ }^{208} M B$ II, p. 114.

${ }^{209}$ MB II, p. 114.
} 
A passagem que inclui a famosa frase do irado mameluco não é, portanto, parte de uma descrição pormenorizada do que fizeram os moradores de Santo André da Borda do Campo durante os quatro meses de que trata a carta. Seguindo a tradição retórica da epistolografia jesuítica, são apresentados pequenos episódios isolados que sejam, no entender de Anchieta, representativos da adoção, por parte desses específicos mamelucos e seu pai português, dos costumes ditos gentílicos, da má influência que exercem sobre os indígenas no que tange aos costumes e à submissão aos padres, da violência e concubinato por eles praticados.

Não se entende aqui, ao considerar tal passagem parte de uma construção retórica, que sejam informações falsas, no sentido de meros artifícios para convencer o leitor. As informações apresentadas pelo padre são tanto mais verídicas quanto mais representativas forem de um estado geral das coisas. Ao colocar na boca do mameluco a afirmação de que "vararia com flechas duas inquisições" 210 , tem-se, com as flechas, mais um, dentre outros exemplos apresentados, de adoção por parte desses mamelucos dos costumes gentílicos; e com o ataque à Inquisição, indica-se sua insubmissão a qualquer autoridade. Se o anônimo mameluco realmente proferiu a polêmica frase nesses termos é algo que permanece no campo do irrecuperável. Para além da possibilidade de Anchieta ter ouvido esse relato indiretamente, com possíveis distorções, ou ter carregado nas cores, intencionalmente ou não, há o fato mais evidente da narrativa possuir um teor abertamente condenatório, apresentando unilateralmente uma relação de conflito. A versão de um desafeto não é, obviamente, o caminho mais seguro para recuperar um fato objetivamente. Tudo isso, contudo, não tornaria a passagem menos representativa do que Anchieta entendia ser o estado de coisas na região. Como dissemos anteriormente, no interior do conteúdo desses quatro parágrafos a Inquisição tem menor importância do que a maneira desrespeitosa do mameluco dirigir-se a uma autoridade.

Considerando, porém, toda a construção retórica que envolve o documento em questão e submetendo-o à comparação com outros relatos, o trecho oferece informações preciosas sobre a povoação de João Ramalho. Temos, por um lado, a questão da adoção por esses cristãos de costumes gentílicos e a prática da mancebia; tendência frequente nos relatos e que não acreditamos ser possível reduzir a um subjetivo ataque jesuítico. Destrincharemos esses temas em tópicos posteriores, relacionando sua função retórica com a situação concreta à qual se ligam.

${ }^{210} M B$ II, p. 115. 
Ao tratar da má influência que os mamelucos e seu pai português exercem sobre os índios, Anchieta utiliza uma série de adjetivos vagos como "torpe", "dissoluta", "nefanda e abominável depravação" ${ }^{211}$ sem, contudo, adentrar muito nos detalhes de o que seriam essas práticas. A adjetivação acompanha sempre a acusação de dificultar o trabalho dos padres com os indígenas. O dado concreto possível de ser apreendido, a partir do qual Anchieta formula sua avaliação condenatória, é uma disputa entre jesuítas e colonos em torno da população indígena. É essa disputa que orienta a construção retórica e dá sentido ao relato sobre os mamelucos de Ramalho, inserindo-o na carta como parte do tema da evangelização dos indígenas do planalto, no qual está incluído até mesmo no que diz respeito à organização formal do texto. Considerando a descrição a respeito de João Ramalho e seus filhos no interior desse fio condutor e da estrutura formal em que está compreendida, podemos obter algumas informações para além daquelas que o jesuíta tinha intenção de transmitir. Nesse sentido, o trecho inicial apresenta elementos importantes:

De facto, alguns cristãos nascidos de pai português e mãe brasílica, que estão apartados de nós 9 milhas numa povoação de Portugueses, não cessam nunca de esforçar-se, juntamente com o seu pai, por lançar a terra a obra que procuramos edificar com a ajuda de Deus, pois exortam repetida e criminosamente os catecúmenos a apartarem-se de nós e a crerem neles, que usam arco e frechas como os índios $[\ldots]^{212}$.

É possível identificar uma diferenciação concreta entre o elemento português (João Ramalho) e o mestiço (seus filhos), ainda que a argumentação de Anchieta busque justamente apresentá-los de forma conjunta. A utilização da palavra “cristãos" para designar os mamelucos Ramalhos não se refere, nesta passagem, apenas ao fato de serem batizados. A polissemia da palavra "cristão" na correspondência jesuítica torna imperativo, como já apontamos, analisar cuidadosamente o contexto em que é utilizada. O trecho busca exemplificar, por meio do caso dos filhos de Ramalho, a avaliação geral anterior de que a natureza "bárbara" e "indômita" dos indígenas não era tão admirável quanto a "malícia" dos próprios cristãos. Os indígenas, no caso, são “estes [do sertão da capitania de São Vicente] entre os quais trabalhamos" ${ }^{213}$, dos quais se descrevem os costumes, a organização social e familiar etc. Aos indígenas da região, tomados em sentido geral, são contrapostos, portanto, os europeus (“cristãos"). Dessa maneira, os filhos mamelucos de João Ramalho aparecem não apenas conjuntamente com os colonos, mas são até mesmo utilizados para exemplificar as práticas do grupo em geral. Não obstante se indique sua origem mestiça ao início do trecho, é

${ }^{211} M B$ II, pp. 115-116.

${ }^{212} M B I I$, pp. 114-5, grifo nosso.

${ }^{213} M B I I$, p. 113. 
a inserção na esfera cristã (europeia) que justifica a indignação pela adoção dos costumes gentílicos: "e são cristãos, nascidos de pai cristão"214. A posição do mameluco nessa sociedade não é facilmente identificável, notadamente nesse período inicial de pequena presença portuguesa. Na correspondência jesuítica, ele aparece ora claramente destacado, ora muito próximo ao português.

Os filhos de João Ramalho, ao que tudo indica, não ocupavam o espaço marginal que progressivamente assumiu o mameluco no planalto com o incremento mais efetivo da presença portuguesa. Parecem pertencer àquele grupo de mamelucos que se integravam mais ao ambiente dos colonos ${ }^{215}$. Sem menosprezar esse fato, o tratamento conjunto de mamelucos e brancos na argumentação de Anchieta, por outro lado, permite-lhe aplicar a esse caso específico um esquema interpretativo muito frequente nas cartas jesuíticas: por meio de uma comparação com o indígena, acentua-se as características negativas que se busca apontar nos “cristãos" (colonos) ou as positivas que se busca apontar no indígena, de acordo com o caso. É uma das maneiras com que o colono aparece na correspondência jesuítica em função do tema central da evangelização dos índios, como tratamos no tópico anterior. No trecho em questão, é a dificuldade que João Ramalho e seus filhos colocam à atividade missionária que os situa conjuntamente na aplicação dessa linha argumentativa. Entretanto, ainda que Anchieta apresente-os dessa forma, há uma divisão subentendida no trecho que nos fornece indícios dos limites dessa caracterização comum de mamelucos e portugueses. Os dois primeiros parágrafos, iniciados com a citação acima e referentes aos danos causados aos indígenas e à adoção de seus costumes, concentram-se nos filhos, figurando o próprio Ramalho somente nas avaliações generalizantes, como a destacada em itálico, mas não nos episódios exemplificadores. É no terceiro parágrafo que o jesuíta passa a tratar do alcaide-mor de Santo André, identificando seu tempo de permanência na terra (50 anos), o parentesco com o Padre Manuel de Paiva e formulando as acusações de poligamia e mancebia.

Por mais clara que fique a intenção de José de Anchieta em acusar João Ramalho na mesma intensidade que os filhos, e até mesmo responsabilizá-lo pela "maldade" destes, acaba por se insinuar na narrativa o fato social da diferenciação entre o elemento português e o mameluco no que diz respeito à adoção dos costumes indígenas. $\mathrm{O}$ único caso em que o missivista indica concretamente a mesma prática para pai e filhos é quando aborda os temas da mancebia e da poligamia. Não é de pouca importância que por ocasião da tentativa de

\footnotetext{
${ }^{214} M B$ II, p. 115.

${ }^{215}$ Valemo-nos aqui do quanto aponto Ronaldo Vainfas acerca da plasticidade da situação do mameluco na sociedade colonial brasileira (A heresia dos índios: catolicismo e rebeldia no Brasil colonial. São Paulo: Companhia das Letras, 1995, pp. 141-51).
} 
aproximação entre João Ramalho e Manuel da Nóbrega, é unicamente ao problema conjugal que se buscou dar solução.

Apesar de parecer uma obviedade afirmar que os mestiços seriam mais influenciados culturalmente pelos índios, a delimitação desses espaços de identidade está longe de ser consensualmente resolvida na historiografia. Vimos, no tópico anterior, como a abertura do europeu à influência indígena foi constantemente vista como característica da realidade do planalto, não sendo fácil identificar os elementos do legado cultural europeu aos quais os colonos mais se apegariam, e, por outro lado, quais os costumes indígenas que adotariam sem maiores escrúpulos, sendo comum a imagem de um "paulista" profundamente indianizado ${ }^{216}$. Dado que a acusação de adoção de costumes gentílicos era frequentemente mobilizada em conflitos variados, inclusive contra os próprios jesuítas, uma melhor definição dos limites e da abertura à influência cultural indígena é fundamental para se compreender a dinâmica social e cultural do planalto paulista. Trataremos mais detidamente desses temas relativos à adoção de costumes gentílicos pelos moradores de Santo André da Borda do Campo e São Paulo no próximo capítulo.

As questões da poligamia e do concubinato podem ser compreendidas mais profundamente comparando-se a descrição de Anchieta com as que fornece Manuel da Nóbrega em junho e agosto de $1553^{217}$, cada qual reintroduzida em seu respectivo contexto narrativo. Na carta de Anchieta que temos discutido, a seguir aos exemplos de gentilidade dos mamelucos de Ramalho, afirma-se:

Este [João Ramalho] passou quase 50 anos nesta região, junto com uma concubina brasílica, e gerou muitos filhos: a salvá-los dedicaram os Irmãos da nossa Companhia todos os cuidados e canseiras [...]. Notando, porém, que nenhum fruto se obtinha dele, mas que pelo contrário continuavam os maiores escândalos - por causa da maneira de viver torpe e dissoluta tanto do pai como dos filhos, que estão unidos com duas irmãs e duas filhas do mesmo pai - começaram os Irmãos a exercer sobre eles algum rigor e violência, sobretudo separando-os da comunhão da Igreja. Mas eles, [...] que nos têm o maior ódio e procuram prejudicar-nos por todos os modos, [...] principalmente esforçando-se por inutilizar a doutrina em que instruímos e educamos os Índios, e por concitar o ódio deles contra nós ${ }^{218}$.

Destaca-se no trecho a proeminência da relação com a concubina brasílica (Bartira), que denota certa estabilidade e dentro da qual foram gerados os muitos filhos. Tanto Ramalho quanto os filhos, no entanto, são acusados de estarem "unidos" com "duas irmãs" (elas entre si), o que configuraria poligamia. A situação conjugal do alcaide-mor do campo também

\footnotetext{
${ }^{216} \mathrm{O}$ termo paulista vem aqui entre aspas devido às problemáticas conceituais discutidas no tópico anterior.

${ }^{217} M B I$, carta 69 , pp. 489-503, e carta 75 , pp. 521-27.

${ }^{218}$ MB II, pp. 115-6, grifo nosso.
} 
aparece relacionada aos conflitos a respeito da população indígena, já que o "ódio" aos jesuítas, por suas admoestações, levaria-os a prejudicar o trabalho de evangelização. Os elementos da descrição são muito semelhantes aos que apresentara Nóbrega em carta ao padre Luís Gonçalves da Câmara, datada de junho de 1553:

[...] su vida es principal estorvo para con la gentilidad, que tenemos, por él ser muy conoscido y muy aparentado con los indios. Tienen muchas mugeres él y sus hijos, andan con hermanas y tienen hijos dellas así el padre como los hijos. [...] Este estando escomulgado por no se confessar y no queriendo los nuestros Padres celebrar con él, dixo que también los Padres y Hermanos pecavan con las negras, lo que hizo presumir ser alguna cosa [...] y hize la verdad pública a todos y ganóse quitar de los coraçones alguna presumpción $[\ldots]^{219}$.

Esta carta trata de uma ampla gama de temas, alguns de teor bastante prático e específico, entremeados às descrições das populações indígenas, o relato das atividades dos membros, os planos de adentrar o sertão etc. Não há, portanto, aquela conformação mais sistemática presente nas quadrimestrais, como a de Anchieta anteriormente analisada. A passagem citada insere-se em um relato do estado de coisas na capitania de São Vicente, sem a vinculação explícita e formal ao tema do conflito pelo indígena. Entretanto o vínculo pode ser reconhecido no início do próprio trecho, ainda que não sirva de fio condutor para o conjunto da descrição, como no relato de Anchieta. A poligamia do pai e dos filhos é apontada - também no que toca às irmãs - sem que figure a mais estável relação com a índia Bartira.

Mais linhas gastará o padre Manuel da Nóbrega a seguir para defender os padres e irmãos da acusação de que "pecavan con las negras" (índias), levantada pelo andreense, do que para descrever sua situação. A caracterização negativa de Ramalho e seus filhos cumpre também a função de desqualificar as acusações levantadas, como fica evidente ao final da passagem citada. Trata-se de uma das raras vezes em que a correspondência jesuítica apresenta com nitidez as relações concretas nas quais estão inseridas, permitindo recuperar parcialmente a pluralidade de vozes daquele contexto, como acontece analogamente nas cartas que fazem parte do conflito com o bispo Sardinha. No mais das vezes, essa pluralidade só pode ser entrevista por meio de extenso aparato crítico. A acusação de que também os jesuítas "pecavam” com as índias é desmentida pelo padre Nóbrega, após desqualificar seu autor e afirmar ter investigado o caso em detalhes ${ }^{220}$. Evidencia-se, entretanto, que os jesuítas também não estavam alheios às acusações de tratos ilegítimos, dirigida repetidamente por eles

\footnotetext{
${ }^{219} M B$ I, pp. 498-9, grifos nossos.

${ }^{220}$ MB I, pp. 498-9
} 
aos colonos e ao clero secular. Não nos cabe apontar a veracidade das acusações ou subscrever a defesa realizada por Nóbrega. O importante aqui é destacar que a desqualificação moral por meio desse tipo de acusação não fazia parte somente do repertório jesuíta, ainda que a correspondência jesuítica, dado seu caráter institucional, obviamente apresente os membros da ordem como os legítimos guardiões da castidade, contrapondo-os aos seculares e leigos. Certamente o problema das relações ilegítimas não possui a mesma intensidade nestes diferentes grupos, mas é imprescindível considerar a parcialidade desse tipo de informação.

Em carta de agosto de 1553, pouco mais de dois meses após a anterior, Manuel da Nóbrega apresenta ao mesmo Luís Gonçalves da Câmara uma descrição muito mais branda de João Ramalho, fruto de uma tentativa de aproximação. Diferentemente das duas cartas analisadas anteriormente, esta tem a descrição da situação de Ramalho como seu principal assunto, tratando apenas marginalmente e rapidamente das atividades dos missionários da Capitania de São Vicente. Para um relato mais detido do "fructo que en esta tierra se haze", Nóbrega remete às outras cartas que de São Vicente se escreverão ${ }^{221}$. Vê-se, mais uma vez, que a comunicação ocorria de maneira articulada, com uma divisão de atribuições e de modalidades de cartas. As informações acerca de João Ramalho que o padre apresenta cumprem o objetivo prático de conseguir-lhe uma dispensa para poder casar com sua concubina índia:

En este campo está un Joán Ramallo el más antiguo hombre que hay en esta tierra. Tiene muchos hyjos y muy aparentados en todo este sertán, y el maior dellos llevo yo hahora comigo al sertán por más autorizar nuestro ministerio, porque es mui conocido y venerado entre los gentiles, y tiene hijas casadas con los principales hombres desta Capitania, y todos estos hyjos e hyjas son de una india hija de los maiores y más principales desta tierra, de manera que en él y en ella y en sus hijos speramos tener un grande medio para conversión destos gentiles [...].

Quando vino de la tierra, que avrá 40 años y más, dexó su muger allá viva y nunqua más supo della, mas que le parece que deve ser muerta, pues ha tantos años. Desea mucho casarse com la madre destos sus hyjos. Ya allá se escrevió y nunqua vino respuesta deste su negocio, y portanto es necessario que V. R. luego embíe a Bouzela, tierra del Padre Maestre Simón, y de parte de N. Señor lo requiero, porque si este hombre estuviere en estado de gracia hará N. S. por él mucho en esta tierra, pues estando en el peccado mortal, por su causa la sustentó hasta hahora [...].

[...] Si el Nuncio tuviere poder, avan dél dispensación particular para este mismo Joán Ramallo poder casar con esta india, no obstante que oviese conocido otra su hermana y qualesquier otras parientas della; y así para otros dos o tres mestizos que quieren casar con indias de que tienen hijos no

${ }^{221} M B I$, p. 522. 
obstante qualquier affinidad que entre ellos aya ${ }^{222}$.

Vê-se que o combate à mancebia e qualquer tipo de relação ilegítima era, efetivamente, caro à Companhia de Jesus, não sendo apenas um recurso retórico mobilizado em função do conflito indígena. O caráter prático desta carta, voltada quase exclusivamente ao problema da dispensa, e o momento de aproximação de que faz parte levam a diferenças consideráveis na abordagem. Primeiramente, a acusação de adoção dos costumes gentílicos não aparece. Mesmo que a carta se concentre na resolução da situação conjugal, com a qual o tema não está diretamente ligado, há uma descrição geral de Ramalho e seus filhos, como nas anteriores, que não trata da questão. Há ainda uma clara identificação de uma relação estável, a qual se busca tornar legítima, e os demais tratos ilegítimos são reduzidos a encontros esporádicos ("no obstante oviese conocido otra sua hermana"), à diferença da caracterização explícita de poligamia presente em seu relato anterior.

${ }^{222} M B I$, pp. 524-6. 
CAPÍTULO 2

A VIVÊNCIA RELIGIOSA DOS COLONOS: INTERCULTURALIDADE E DIMENSÃO POLÍTICA 


\subsection{Os "costumes gentílicos"}

A influência dos costumes indígenas na vida cotidiana dos colonos de Santo André e São Paulo é um tema largamente tratado pela historiografia referente à região, sendo frequentemente proposta a imagem de um paulista ${ }^{223}$ profundamente indianizado. A construção dessa imagem, bem como da oposta, um paulista civilizador e nobilitado, dependeu em larga medida da seleção documental efetuada pelos historiadores. Na interpretação do colono indianizado ou, no mínimo, pouco afeito à prática formal do catolicismo e aos "costumes cristãos", a correspondência jesuítica ocupa um papel central, sobretudo quando nos atemos a algumas passagens mais polêmicas. A descrição dos colonos nas narrativas epistolares insere-se, como vimos anteriormente, em uma prática textual complexa, que aborda esse tema a partir de premissas particulares. O debate relativo à influência indígena no cotidiano do planalto paulista gira em torno da demarcação dos limites dessa abertura dos colonos às técnicas e costumes nativos, uma vez que as lacunas documentais deixam margem para muita divergência. Consideramos que nossa pesquisa pode contribuir, ainda que modestamente, para essa discussão, reavaliando o que as cartas jesuíticas podem informar a esse respeito.

Ao tratar do tema da adoção dos "costumes dos gentios" pelos colonos, não seria pertinente partir de uma delimitação do que seriam os costumes propriamente religiosos, uma vez que, como veremos, a afirmação desta diferenciação é justamente o aspecto que norteia as descrições presentes nos documentos, variando de acordo com a situação em que estes foram produzidos e a posição que exprimem. É imprescindível aqui utilizar o conceito de religião em perspectiva histórica, evitando balizar a análise a partir de categorias alheias àquele contexto $^{224}$. Dessa forma, um costume que poderia ser apresentado como inofensivo em alguns momentos, como o uso das línguas ou técnicas nativas, poderia, em determinadas situações, ajudar a compor uma descrição negativa ligada a uma "barbarização" do branco, em um contexto no qual os costumes não são facilmente dissociáveis de uma identidade civilizacional mais ampla, baseada na religião.

\footnotetext{
${ }^{223}$ As problemáticas referentes ao conceito de "paulista", de discutível aplicação para o século XVI, foram tratadas no tópico 2 do primeiro capítulo. Aludimos aqui à utilização generalizante que estende o conceito para todo o período colonial.

${ }^{224}$ Para uma síntese do debate teórico referente à historicização do conceito de religião, cf. MASSENZIO, Marcello. A história das religiões na cultura moderna. São Paulo: Hedra, 2005; BRELICH, A. "Prolegómenos a una historia de las religiones". In: PUECH, Henri-Charles (org.). Historia de las religiones, vol. 1: Las religiones antiguas I. $6^{\text {a }}$ ed. Madrid: Siglo XXI, 1986, pp. 30-97.
} 
Assim, não nos cabe afirmar se os habitantes do planalto teriam sido "bons católicos", ou "selvagens" indianizados. A formação das identidades ou, em outras palavras, dos limites onde se situaria a abertura aos costumes locais era móvel, e fazia parte das relações políticas e sociais ali presentes. Por mais discordâncias que haja em relação aos hábitos dos moradores de Santo André e de São Paulo, não há dúvida que eles se reconheciam como cristãos em relação aos gentios, ou como "brancos" em relação aos "negros" (índios). Todavia, nem sempre é evidente como essas identidades compunham-se socialmente e etnicamente, principalmente em relação ao espaço ocupado pelo mameluco, tampouco quais práticas religiosas compreendiam. A análise mais específica da relação dos colonos com a liturgia católica, a recepção dos sacramentos e o aspecto "civil" (no sentido do pertencimento às estruturas políticas municipais) da observância religiosa será realizada no terceiro tópico deste capítulo. No presente tópico, interessa-nos o enfoque mais amplo na relação cultural entre portugueses e indígenas e no entendimento que dela apresentavam os textos jesuíticos.

Consideramos que as tentativas de recompor pormenorizadamente a relação cotidiana dos colonos do planalto com a Igreja, institucionalmente entendida, esbarram em lacunas documentais nada desprezíveis e utilizam frequentemente recortes relativamente arbitrários. De fato, o estudo que Afonso de Escragnolle Taunay fez das atas da Câmara da vila de São Paulo do século XVI apresenta-nos uma população piedosa e engajada nas atividades paroquiais, ainda que não faltem referências do autor à adoção de práticas indígenas em outros setores da vida cotidiana. As características deste material privilegiam, evidentemente, o aspecto mais oficial da vida pública de São Paulo, e as conclusões decorrentes acabam por refletir no texto do autor essa parcialidade ${ }^{225}$. Quando trata da relação dos moradores da vila com a Igreja, Taunay privilegia os anos posteriores a 1588 , com as discussões sobre a construção da matriz e relações da Câmara com o recém-nomeado pároco $^{226}$. Não há muito nas atas sobre o período anterior. O autor justifica as frequentes referências sobre a necessidade da igreja matriz e de um pároco a partir de 1588 por se tratar de um período distinto. Anteriormente, segundo ele, a assistência dos jesuítas era suficiente.

A dificuldade em se recuperar os pormenores da vida cotidiana dos primeiros portugueses e mamelucos do planalto não reside apenas na parcialidade dos documentos, mas também na escassez de dados mais concretos sobre a maioria dos aspectos que compunham

\footnotetext{
225 TAUNAY, Afonso de E. São Paulo nos primeiros anos (1554-1601): ensaio de reconstituição social; São Paulo no Século XVI: história da vila piratiningana. Coordenação de Paula Porta. São Paulo: Paz e Terra, 2003 [1920, 1921]; Actas da Camara da villa de S. Paulo, vol. I (1562-1596). Publicação official do Archivo Municipal de S. Paulo. São Paulo: Duprat \& C. a 1914.

${ }^{226}$ TAUNAY, op. cit., pp. 58-70.
} 
esse cotidiano. $\mathrm{O}$ estudo mais importante sobre a adoção de práticas indígenas pelos colonos de São Paulo é ainda o clássico Caminhos e Fronteiras ${ }^{227}$, no qual Sérgio Buarque de Holanda desenvolve a ideia, já presente em Raízes do Brasil ${ }^{228}$, de que a situação do planalto, profundamente marcada pelo movimento, pelo dinamismo e pela assimilação do indígena, decorre de uma imposição das circunstâncias para se levar a cabo o mesmo ideal de permanência e estabilidade das povoações da costa. Os estudos que compõem o livro focamse na vida material por ser o aspecto em que se daria a maior abertura dos adventícios à influência nativa. Ainda que o autor aborde São Paulo colonial de forma mais geral, as referências documentais ao primeiro século são relativamente escassas para parte dos temas e, mesmo tomando-o em conjunto com os dois séculos posteriores, Sérgio Buarque de Holanda vale-se frequentemente de analogias com a situação do interior de São Paulo que lhe era contemporânea, entendida como resquício dos tempos passados. O recurso a exemplos coevos busca preencher as consideráveis lacunas documentais sobre a vida material do planalto paulista. Ainda que seja lógico supor que a influência indígena em usos e técnicas contemporâneos do interior paulista seria ainda mais intensa no período colonial, no qual a possibilidade de substituí-los pelos provenientes da Europa era bastante restrita, torna-se evidente a dificuldade em se estender essa interpretação para determinados temas.

O caso da língua falada pelos colonos do planalto exemplifica muito bem essa questão. Em outro texto, também clássico, A língua-geral em São Paulo ${ }^{229}$, o autor desenvolve a ideia, retomada então ${ }^{230}$, de que a língua portuguesa suplantaria a língua geral no planalto somente no século XVIII. Seguindo a proposta de Teodoro Sampaio, afirma que, no ambiente doméstico, prevalecia a utilização da língua geral, ficando o português relegado a um âmbito oficial. É importante destacar que a língua geral, ela mesma instrumento e produto do processo de mediação cultural entre europeus e indígenas, foi sistematizada pelos jesuítas, a partir da gramatização do tupi e, posteriormente, do guarani, como instrumento catequético voltado à atividade missionária ${ }^{231}$. Na análise de Buarque de Holanda, "língua geral" é

${ }^{227}$ HOLANDA, Sérgio Buarque de. Caminhos e fronteiras. $3^{\text {a }}$ ed. São Paulo: Companhia das Letras, 1994 [1956].

${ }^{228}$ HOLANDA, Sérgio Buarque de. Raízes do Brasil. 26a ed. São Paulo: Companhia das Letras, 1995 [1936], p. 131.

${ }^{229}$ Ibid., pp.122-33. O texto foi publicado primeiramente nas páginas de O Estado de São Paulo, no ano de 1945 e incorporado na reedição da obra.

${ }^{230}$ HOLANDA, Caminhos e fronteiras, op. cit., p. 10.

${ }^{231}$ Uma análise pormenorizada da língua geral como parte do processo de mediação cultural está em AGNOLIN, Adone. "Catequese e tradução: Gramática cultural, religiosa e lingüística do encontro catequético e ritual nos séculos XVI-XVII". In: MONTERO, Paula (org.). Deus na Aldeia: missionários, índios e mediação cultural. São Paulo: Globo, 2006, pp. 143-207 (para ideia da língua geral como "produtor e produto" da mediação cultural cf. p. 162); . Jesuítas e Selvagens: A negociação da fé no encontro catequético-ritual americano-tupi (séc. 
utilizada simplesmente como sinônimo de língua tupi, fazendo referência à comunicação cotidiana entre os colonos e a população indígena do planalto e as "descidas" do sertão. A língua tupi possuía efetivamente grande abrangência e servia como instrumento de comunicação entre grupos indígenas diversos em uma extensa área, dado este que, ainda que superdimensionado, levou os jesuítas a sistematizá-la como instrumento de comunicação e catequese para com populações indígenas de origem diversificada. $O$ tupi adquire progressivamente "características de uma 'língua (voltada para a comunicação) colonial", fato "tanto mais evidente quanto menos essa língua geral se mostrava voltada para a comunicação com grupos indígenas tupi - na medida em que esses estavam desaparecendo" 232 . Um exemplo interessante desta característica colonial adquirida pela língua tupi nos é dado por José de Anchieta, que afirma, em uma carta de 1565, ter se valido da "lengua brasíllica" para se comunicar com um francês calvinista durante as negociações com os tamoios em Iperoig ${ }^{233}$.

Não é nosso objetivo abordar a problemática da sistematização da língua geral pelos jesuítas, suas características e de que maneira se relacionava com a língua efetivamente empregada na comunicação entre colonos portugueses e indígenas, dado que muitos destes viviam em aldeamentos administrados pelos inacianos. Pretendemos tão somente levantar alguns questionamentos acerca da relação entre a divisão linguística e a estrutura social do planalto, com foco na população branca e mameluca. Valemo-nos, dessa forma, do sentido mais genérico de "língua geral", tal como utilizado por Buarque de Holanda.

O conjunto de dados disponíveis para o período entre os séculos XVI e XVIII não deixam dúvida da grande difusão da língua geral entre a população branca e mameluca do planalto. No entanto, dado o caráter esparso das informações, é difícil situar onde se localizaria o limite entre o uso do português e da língua geral para as diferentes camadas da população. É possível, partindo da mesma base documental, reconhecer um maior alcance do uso do português. Neste sentido, John Monteiro propõe que a divisão linguística refletia a estrutura social do planalto:

A rigor, a divisão lingüística de São Paulo refletia a estrutura bipolar da sociedade colonial: na sua base, os escravos provenientes de diversos grupos étnicos e lingüísticos comunicavam-se na versão paulista da língua geral, baseada num padrão guarani; no topo, a comunidade luso-brasileira

XVI - XVII). São Paulo: Humanitas Editorial, 2007, principalmente pp. 41-107.

${ }^{232}$ AGNOLIN, Adone. "Catequese e tradução: Gramática cultural, religiosa e lingüística do encontro catequético e ritual nos séculos XVI-XVII”. In: MONTERO, Paula (org.). Deus na Aldeia: missionários, índios e mediação cultural. São Paulo: Globo, 2006, p. 158.

${ }^{233} M B I V$, p. 138. 
diferenciava-se da massa cativa por meio do uso da língua colonial, embora, inevitavelmente, entrasse em contato diário com o guarani do lugar ${ }^{234}$.

Na interpretação de Monteiro, o domínio da língua geral ou qualquer língua indígena entre a população branca era, antes que um fato cotidiano, uma "respeitável especialização, e a fluência numa dessas línguas limitava-se apenas aos maiores sertanistas" ${ }^{235}$. No cerne dessas posições parcialmente divergentes, focadas principalmente no século XVII, estão algumas referências documentais bastante conhecidas. Dentre as mais importantes, há o frequentemente citado comentário do bispo de Pernambuco em relação ao sertanista Domingos Jorge Velho, de 1697: "Este homem é um dos maiores selvagens com que tenho topado: quando se avistou comigo trouxe consigo língua, porque nem falar sabe, nem se diferença do mais bárbaro Tapuya mais que em dizer que é Cristão"236. Outra referência importante fornece-nos Antônio Vieira, em conhecida passagem acerca da administração do gentio:

É certo que as famílias dos portuguezes e indios de São Paulo estão tão ligadas hoje humas ás outras, que as mulheres e os filhos se criam mystica e domesticamente, e a lingua que nas ditas famílias se fala he a dos indios, e a portugueza a vão os meninos aprender à escola $[\ldots]^{237}$.

Em ambos os casos é necessário lidar com o inevitável problema da parcialidade do testemunho e, no caso de Vieira, tem-se mais um episódio da construção de uma imagem do paulista pelos jesuítas. Mesmo Sérgio Buarque de Holanda, que utiliza as duas citações para fundamentar a interpretação do predomínio da língua geral em São Paulo, reconhece essa dificuldade metodológica e procura superá-la adicionando mais referências. Ainda que se recuse a atribuir o conteúdo da passagem apenas ao caráter conflituoso da relação entre jesuítas e paulistas ${ }^{238}$, reconhece a possibilidade de que

Vieira, conhecendo apenas de informações o que se passava em São Paulo, tenha sido levado facilmente a repetir certas fábulas que, entre seus próprios companheiros de roupeta, correriam a respeito dos moradores da capitania sulina não é contudo improvável ${ }^{239}$.

\footnotetext{
${ }^{234}$ MONTEIRO, John Manuel. Negros da Terra: índios e bandeirantes nas origens de São Paulo. São Paulo: Companhia das Letras, 1994, p. 165.

${ }^{235}$ Ibid., p. 164.

${ }^{236}$ Carta de D. frei Francisco de Lima, bispo de Pernambuco, apud MONTEIRO, op. cit., p. 164.

${ }^{237}$ VIEIRA, Antônio. Obras Várias, I (Lisboa, 1856), p. 249, apud HOLANDA, Sérgio Buarque de. Raízes do Brasil. $26^{a}$ ed. São Paulo: Companhia das Letras, 1995 [1936], pp. 122-3.

${ }^{238}$ Reiteramos que, no momento em que escreve Vieira, o conceito de "paulista" faz já parte do vocabulário jesuítico.

${ }^{239}$ HOLANDA, op. cit., p. 123.
} 
Tanto nesse caso, como nas outras referências que apresenta, o autor busca anteciparse às objeções que ele próprio já identifica que poderiam ser levantadas. Não lhe escapou que poderia se considerar demasiadamente genérica a descrição do paulista, tanto no trecho de Vieira como nos outros testemunhos que elenca, e que seria possível relacioná-la a uma camada mais baixa da população, predominantemente mestiça. Para responder a essa objeção, apresenta o já citado testemunho do bispo de Pernambuco sobre Domingos Jorge Velho, por se tratar de um grande sertanista de ascendência predominantemente portuguesa. Contudo, há uma dificuldade ainda maior em tal testemunho, dada a existência de uma carta ao rei redigida por ele e diversas assinaturas suas nos registros do cartório de Santana de Parnaíba ${ }^{240}$. Para Sérgio Buarque de Holanda, entretanto, há ainda a possibilidade de se admitir que "sendo porventura sua a letra com que foram redigidos os escritos, não o seriam as palavras e, ainda menos, as idéias” ${ }^{, 41}$, possibilidade que é, de qualquer maneira, inverificável. Desta forma, fragiliza-se a recusa a atribuir estes episódios a uma camada específica da população.

A interpretação que John Monteiro dá aos testemunhos seiscentistas de que os paulistas não falavam o português caminha em outra direção:

[...] parece provável que, acompanhando a evolução do regime de escravidão indígena ao longo do século XVII, tenha se desenvolvido uma forma ancestral do dialeto caipira, aliás fortemente marcado pela presença de palavras de origem guarani ${ }^{242}$.

Dessa forma, o bispo, bem como outros observadores portugueses da época, teria dificuldade em compreender o "português colonial, corrompido pela presença de barbarismos africanos e indígenas" e classificava-o como uma língua à parte ${ }^{243}$. A dificuldade em se confirmar essa hipótese está justamente no caráter fragmentário e indireto das informações disponíveis, como destacamos mais acima. De qualquer maneira, essa interpretação encaixase melhor com as referências documentais, já que a aceitação integral do comentário em relação à incapacidade de manejo do português por um sertanista influente como Domingos Jorge Velho não poderia ser facilmente harmonizada com o uso, bastante documentado, do português em âmbito oficial. Os demais testemunhos apresentados na discussão desse tema possuem limitações similares, ainda que consideremos, como John Monteiro, que esteja suficientemente documentado o uso do português entre os colonos do planalto para além do

\footnotetext{
${ }^{240}$ MONTEIRO, John Manuel. Negros da Terra: índios e bandeirantes nas origens de São Paulo. São Paulo: Companhia das Letras, 1994, p. 164.

${ }^{241}$ HOLANDA, Sérgio Buarque de. Raízes do Brasil. 26ª ed. São Paulo: Companhia das Letras, 1995 [1936], p. 127.

${ }^{242}$ MONTEIRO, op. cit., p. 164.

243 Ibidem.
} 
âmbito estritamente oficial, o que significa admitir uma clivagem social na configuração linguística da região ${ }^{244}$, já que a predominância do tupi em parte dos moradores está também documentado.

O pano de fundo da discussão acerca da língua é a conformação social e familiar nas vilas do planalto paulista, e a maneira com que a abertura dos povoadores aos costumes indígenas relacionava-se com essa estrutura social. É preciso levar em conta como o mameluco inseria-se nessa sociedade, quais as identidades que estavam em jogo, a articulação entre as áreas periféricas e o núcleo urbano, a diferença de abertura à influência indígena em ambientes distintos etc. Pode-se reconhecer na interpretação de Sérgio Buarque de Holanda o peso adquirido pela ideia de uma população predominantemente mestiça em São Paulo, mesmo que apenas culturalmente, ideia esta que baseia seu estudo sobre a vida material na região ${ }^{245}$. Em outras palavras, podemos afirmar que o autor situaria o idioma da população branca e mameluca além da "fronteira", não o incluindo entre aqueles aspectos institucionais e sociofamiliares em que os adventícios procurariam reter, "tanto quanto possível, seu legado ancestral"246. A interpretação de Buarque de Holanda em relação à língua geral articula referências documentais esparsas e fragmentadas, por meio da ideia do predomínio de um hibridismo cultural, que dilui a diversidade sociocultural do planalto em função das características gerais do "paulista". Há aí um eco de certas imagens tradicionais acerca dos habitantes do planalto, desenvolvidas a partir dos escritos jesuíticos setecentistas.

Os conceitos de "hibridismo" ou "mestiçagem" aplicados às relações culturais carregam alguns problemas que é conveniente esclarecer. Usualmente, pressupõem uma noção de coesão e unicidade em cada uma das culturas em contato, indicando uma mistura entre dois blocos monolíticos. Tal noção obscurece o sentido dinâmico da cultura e a diversidade, muitas vezes conflituosa, dos delineamentos possíveis em cada uma das diferentes culturas em contato, além de impedir o entendimento dos mecanismos de comunicação. Dessa maneira, ao indicarmos a situação cultural do planalto, tanto na análise de Sérgio Buarque quanto na nossa, por meio destes termos, pressupomos o seu sentido dinâmico.

\footnotetext{
${ }^{244}$ Marilza de Oliveira, em "Para a História social da língua portuguesa em São Paulo", apresenta mais referências documentais do uso do português em ambientes não oficiais, como cartas e bilhetes pessoais retirados dos testamentos e inventários seiscentistas, o que corrobora a interpretação social proposta por John Monteiro. In: CASTILHO, Ataliba Teixeira de (org.). História do português paulista. Série Estudos, Vol. I. Campinas: Institutos de Estudos da Linguagem, 2009, pp. 185-208. Cf. principalmente os anexos, pp. 207-8.

${ }^{245}$ HOLANDA, Sérgio Buarque de. Caminhos e fronteiras. $3^{a}$ ed. São Paulo: Companhia das Letras, 1994 [1956].

${ }^{246}$ Ibid., p. 12.
} 
Para o período de que nos ocupamos, anterior à "era das bandeiras", os registros documentais podem apontar alguns caminhos para se compreender melhor o pano de fundo sociocultural da questão da língua, ainda que não tratem diretamente do idioma falado pelos moradores de Santo André e São Paulo em ambientes públicos e domésticos. O destaque que a figura do "língoa" ou "língua" (intérprete) recebe nos registros documentais indica, ao que parece, tratar-se de uma importante especialização. Não eram utilizados apenas por europeus recém-chegados, como no caso em que Martim Afonso de Sousa leva João Ramalho e Antonio Rodrigues como "linguas d'esta terra"247, mas também por adventícios há muito estabelecidos no Brasil, como o próprio Manuel da Nóbrega em meados da década de $1560^{248}$.

Entretanto, não é possível saber em que idioma se dava a comunicação no ambiente civil e familiar neste momento de predomínio da união entre portugueses e índias, com filhos mamelucos. É interessante apontar que o esforço de Anchieta e Nóbrega em apresentar os filhos mestiços de João Ramalho profundamente indianizados não incluía a acusação de imperícia no português, como se daria nos registros seiscentistas tratados anteriormente. Por mais que a negação de um fato não comprove o seu contrário, essa ausência nas acusações jesuíticas quinhentistas indica, no mínimo, uma diferença de critérios utilizados na construção de uma imagem “indianizada” dos moradores de São Paulo.

A prática jesuítica de confessar por meio de intérprete, condenada pelo bispo D. Pedro Fernandes, não era utilizada apenas com índios, mas também com mestiças, mulheres de portugueses, que não falavam sua língua, como veremos a seguir. Por outro lado, alguns desses intérpretes eram também mestiços, o que indica, mais uma vez, a indefinição da situação do mameluco nesta sociedade.

As mesmas problemáticas referentes à língua apresentam-se para outros temas relacionados à influência indígena no cotidiano dos primeiros colonos do planalto. A análise de Sérgio Buarque de Holanda sobre a adoção pelos portugueses de técnicas e costumes indígenas no campo da vida material esclarece em larga medida esse aspecto do cotidiano planaltino, mas parte do reconhecimento que a abertura à influência nativa não seria a mesma na esfera da vida social, familiar e institucional ${ }^{249}$. No que diz respeito ao cotidiano religioso,

\footnotetext{
${ }^{247}$ MARQUES, Manuel Eufrásio de Azevedo. Apontamentos históricos, geográficos, biográficos, estatísticos e noticiosos da Província de São Paulo seguidos da cronologia dos acontecimentos mais notáveis desde a fundação da Capitania de São Vicente até o ano de 1876. São Paulo: Comissão do IV Centenário da cidade de São Paulo, 1954 [1879], tomo II, p. 41.

${ }_{248}^{24}$ José de Anchieta afirma ter acompanhado Nóbrega a Iperoig como intérprete (MB III, p. 564).

249 "A acentuação maior dos aspectos da vida material não se funda, aqui, em preferências particulares do autor por esses aspectos, mas em sua convicção de que neles o colono e seu descendente imediato se mostraram muito mais acessíveis a manifestações divergentes da tradição européia do que, por exemplo, no que se refere às instituições e sobretudo à vida social e familiar em que procuram reter, tanto quanto possível, seu legado
} 
deve-se considerar, portanto, sua estreita ligação com a própria identidade civilizacional, e sua importância na definição dos limites - ou "fronteiras", para usar novamente a bela imagem de Sérgio Buarque de Holanda - do contato entre europeus e indígenas.

O reconhecimento de ser cristão, entretanto, não se traduz simplesmente na adoção a um conjunto estanque de normas ortodoxas. A definição desses limites ocorre no interior de situações políticas concretas, nas quais as vozes em questão procuram dar-lhes os contornos que consideram mais adequados, e que nem sempre são muito nítidos. É dessa forma que podemos compreender a acusação feita aos paulistas do século XVI de adotar costumes indígenas justamente pelos jesuítas, vítimas da mesma acusação por parte de outros setores da Igreja. É bastante conhecida a polêmica envolvendo o conceito de adaptação no ministério da Companhia de Jesus e a defesa que a ordem fazia desta postura a partir da divisão entre práticas inofensivas à fé, que poderiam ser instrumentalizadas para a conversão, e as prejudiciais, que se deveriam combater implacavelmente ${ }^{250}$.

$\mathrm{Na}$ atuação da Companhia em terras brasileiras quinhentistas, a página mais célebre dessa polêmica desenvolveu-se em torno do conflito entre Manuel da Nóbrega e o bispo D. Pedro Fernandes, no qual a escrita epistolográfica cumpriu importante papel $^{251}$. O bispo não desenvolve sua crítica em torno da ideia de adaptação de forma geral, ainda que essa seja a consequência de sua argumentação; questiona diretamente Nóbrega, focando-se em episódios específicos ocorridos na Bahia. Sente-se escandalizado porque o superior jesuíta "confessava ciertas mugeres mistiças por intérprete", principalmente pelo intérprete ser "un niño de los de la tierra, mamaluquo de diez años" ${ }^{, 252}$. Pareceu-lhe uma afronta ao sacramento. No entanto, com exceção desta questão mais polêmica referente à confissão, grande parte de seu escândalo dizia respeito a práticas que Nóbrega entendia como não prejudiciais à fé. O bispo

\footnotetext{
ancestral". HOLANDA, Sérgio Buarque de. Caminhos e fronteiras. $3^{\mathrm{a}}$ ed. São Paulo: Companhia das Letras, 1994 [1956], p.12.

${ }^{250}$ PROSPERI, Adriano. "O missionário". In: VILLARI, Rosario (dir.). O homem barroco. Lisboa: Presença, 1995, pp. 154-61. Um dos registros mais notáveis desse posicionamento na Companhia, para o período, é o "Tratado em que se contém muito sucinta e abreviadamente algumas contradições e diferenças de costumes entre a gente de Europa e esta província de Japão [...]”, escrito pelo jesuíta Luís Fróis em 1585, no qual se apresenta com uma impressionante riqueza de detalhes os costumes dos japoneses, contrapondo-os pontualmente aos correspondentes europeus, com o evidente objetivo de melhor se inserir nessa sociedade e promover sua evangelização. Os capítulos que tratam dos bonzos e seus costumes, e "Dos templos, imagens e cousas que tocam ao culto de sua religião" destoam dos demais pelo tom agressivo de condenação (FRÓIS, Luís. Europa Japão: Um diálogo civilizacional no século XVI. Lisboa: Comissão Nacional para as Comemorações dos Descobrimentos Portugueses, 1993).

${ }^{251}$ Há uma carta do próprio bispo, datada de 1552 e endereçada ao provincial Simão Rodrigues, em Lisboa, e uma sequência de cartas de Nóbrega que fazem referência aos desentendimentos: $M B I$, carta 49, pp. 357-66; carta 51, pp. 367-75; carta 61, pp. 448-59; carta 69, pp. 489-503. O bispo retoma o assunto, no ano seguinte, em carta endereçada ao Reitor do Colégio de S. Antão de Lisboa: $M B$ II, carta 2, pp. 11-2.

${ }^{252}$ MB I, p. 361.
} 
não compartilhava da visão inofensiva de práticas como cortes de cabelos, modos de cantar e tocar instrumentos. Apontava-lhes consequências negativas:

[...] estos gentiles se alaban que ellos son los buenos, pues los Padres y niños tañiam sus instrumentos y cantavam a su modo. Digo que Padres tañiam, porque en la compañia de los niños venía hun Padre sacerdote, Salvador Rodrígez; tañía, dançava e saltava com ellos ${ }^{253}$.

O bispo advertiu Nóbrega de "que no venía aquá hazer lós christianos gentiles, sino a costumbrar los gentiles a ser christianos" 254 . Para D. Pedro Fernandes, a evangelização do indígena deveria começar justamente pela eliminação de seus costumes, e era muito maior motivo de preocupação a perversão dos brancos ${ }^{255}$. A versão do desentendimento que Nóbrega endereça a Simão Rodrigues, a quem também se dirigia D. Pedro Fernandes, baseiase na já citada contraposição entre costumes inofensivos e prejudiciais à fé, demarcando a diferença de posicionamento com o bispo, que não aceitara o argumento de que "[...] nom erão ritos nem custumes dedicados a ídolos, nem que perjudicassem a fee catholica" ${ }^{256}$.

Mesmo levando-se em conta a posição característica da Companhia de Jesus, a delimitação entre esses dois tipos de prática era sempre tênue. O caso de João Ramalho e seus filhos, que abordamos no capítulo anterior, é bastante revelador nesse sentido. A descrição negativa que Anchieta faz dos filhos de Ramalho vale-se tanto de práticas rituais, como matar o inimigo "com a maior crueldade, tingindo as próprias pernas de vermelho e tomando o nome de quem matara em sinal de honra", quanto de práticas meramente técnicas, como usar "arco e frechas como os índios", informação que cumpre um papel retórico na construção da imagem negativa desses mamelucos ${ }^{257}$.

De fato, a indianização de europeus, ainda que descrita em termos de características físicas e técnicas, não deixava de chamar a atenção de comentadores coloniais. Gabriel Soares de Sousa faz menção a um episódio em que:

N'este Rio Grande achou Diogo Paes de Pernambuco, lingua do gentio, um castelhano entre os Pitiguares, com os beiços furados como elles, entre os quaes andava havia muito tempo, o qual se embarcou em uma nao para França, porque servia de lingua dos francezes entre o gentio nos seus resgates $^{258}$.

\footnotetext{
${ }^{253} M B I$, p. 359.

${ }^{254} M B I$, p. 360.

${ }^{255} M B I$, p. 364.

${ }^{256} M B I$, p. 373.

${ }^{257} M B$ II, p. 115

258 SOUSA, Gabriel Soares de. Tratado descriptivo do Brasil em 1587. Introdução e comentários de Francisco Adolpho de Varnhagen. Rio de Janeiro: Typographia de João Ignacio da Silva, 1879, p. 14.
} 
O cronista considerou o fato inusitado o suficiente para referi-lo em meio a descrições quase que exclusivamente topográficas. O caso de São Paulo do primeiro século é, evidentemente, diverso, já que a abertura à influência nativa é reconhecidamente maior, como temos dito. No entanto, como no caso da língua geral, é preciso certo cuidado antes de ratificar a tradicional imagem do paulista indianizado, não muito diferente de um "Tapuia". Temos, por um lado, a natureza das fontes jesuíticas que, no século XVI, descrevem a adoção de práticas gentílicas pelos colonos do planalto. Por outro lado, temos o peso de uma imagem do paulista rebelde e barbarizado, construída a partir do XVII por autores jesuítas e repetidamente reforçada pela historiografia sucessiva.

A descrição da adoção dos costumes gentílicos por João Ramalho e seus filhos, como acompanhamos no tópico anterior, não indicava uma situação específica do planalto e fazia parte de uma construção retórica baseada no tema da assimilação da mão de obra indígena. Encontramos em uma longa carta do padre Manuel da Nóbrega a Tomé de Sousa, de 1559, uma argumentação construída nos mesmos moldes que aquela de José de Anchieta $^{259}$, mas apresentando uma avaliação do Brasil como um todo. É importante aqui transcrever um trecho relativamente longo, para reinseri-lo em seu contexto narrativo.

Em todas estas Capitanias, [...] notei outros [pecados] que muyto mais que todos offendem a divina Bondade e mais lhe atirão de rostro, porque sam contra a charidade, amor de Deus e do proximo. E estes peccados tem sua raiz e principio no odio geral que os christãos tem ao gentio, e não somente lhe avorecem os corpos, mas tambem lhes avorecem as almas, e em tudo estorvão e tapão os caminhos que Christo N. Senhor abrio pera se elas salvarem $[\ldots]$.

Em toda a costa se tem geralmente, por grandes e pequenos, que hé grande serviço de N. Senhor fazer aos gentios que se comão e se travem huns com os outros, e nisto dizem consistir o bem e segurança da terra, e isto aprovão capitãis e prelados, eclesiasticos e seculares, e asi o põem por obra todas as vezes que se offerece; e daqui vem que, nas guerras passadas que se tiverão com o gentio, sempre da[v]am carne humana a comer não somente a outros yndios, mas a seus proprios escravos. Louvão e aprovão ao gentio o comerem-se huns a outros, e já se achou christão mastigar carne humana pera dar com isso bom exemplo ao gentio.

Outros matam em terreiro hà maneira dos Yndios, tomando nomes, e não somente o fazem homens baixos e mamalucos, mas o mesmo capitão, às vezes! Ó cruel custume! Ó deshumana abominação! [...] E não hé muyto que siguão a seu capitão gente que não sei se algum[a] ora do ano está sem peccado mortal $^{260}$.

${ }^{259}$ MB II, pp. 114-5.

${ }^{260} M B$ III, pp. 76-7, grifo nosso. 
Diferentemente da citada carta de Anchieta, Nóbrega restringe a acusação às práticas propriamente rituais, relacionadas à antropofagia e a morte no terreiro. Não apresenta um caso exemplar, como era a praxe, mas sim uma avaliação do estado geral em todas as capitanias. Entretanto, a referência ao "capitão", não nomeado, destoa do caráter genérico da avaliação, indicando um episódio específico que não é abertamente tratado e que em tudo lembra o do próprio João Ramalho. Há ainda a referência a um "cristão", utilizado aqui no sentido de "branco", que teria efetivamente mastigado carne humana, o que o trecho acusatório a Ramalho e seus filhos não apresentava. Nesta carta, como na de Anchieta, as descrições da adoção de costumes dos gentios por brancos e "mamalucos" estavam submetidas ao tema da evangelização do indígena, e do empecilho que os colonos colocavam a esta atividade missionária.

A descrição da adoção de "costumes dos gentios" era frequentemente mobilizada quando se pretendia desqualificar as pessoas em questão, fossem colonos portugueses ou franceses calvinistas. Na longa narrativa que José de Anchieta escreve ao prepósito-geral Diego Laines acerca da paz de Iperoig, enviada em janeiro de 1565, os franceses estabelecidos no Rio de Janeiro são assim descritos:

La vida de los franceses que están en este Rio es ya no solamente oie apartada de la Iglesia Cathólica, mas también hecha salvage. Biven conforme a los Indios comiendo, bibiendo, bailando y cantando con ellos, teñiéndose con sus tintas prietas y bermejas, ornándose con las plumas de los páxaros, andando desnudos a las vezes, sólo con unos pañetes, y finalmente matando contrarios según el rito de los mismos Indios, y tomando nombres nuevos como ellos, de manera que no les falta más que comer carne humana, que en lo más su vida es corruptíssima. Y con esto, y con les dar todo género de armas, incitándolos siempre que nos hagan guerra y aiudándolos en ella, le son aún péssimos ${ }^{261}$.

O trecho apresenta muitos elementos semelhantes à descrição do mesmo Anchieta a respeito dos filhos de Ramalho ${ }^{262}$, mas organizados de maneira um pouco diversa. A narrativa do cativeiro de Iperoig, mais do que uma simples carta edificante, carrega muitos elementos de um relato de viagem, encadeando cronologicamente os episódios e fornecendo descrições dos locais visitados e da população neles existente. Nas informações a respeito dos franceses do Rio de Janeiro não há os episódios exemplificadores como para o caso dos mamelucos de Santo André. O estado geral que se quer comunicar é apresentado sucintamente de maneira descritiva. Os franceses, como os filhos mamelucos de João Ramalho, tornam-se "selvagens" por meio da adoção dos costumes e indígenas, incluindo os rituais (com exceção, nos dois

\footnotetext{
${ }^{261} M B I V$, p. 139.

${ }^{262} M B I I$, pp. $114-5$.
} 
casos, da antropofagia). Se a cristianização do indígena pressupunha a "civilização" de seus costumes - o que está na base da política dos aldeamentos -, o caminho inverso do processo civilizatório também poderia ser trilhado, de acordo com a argumentação de Anchieta. O tornar-se "selvagem", como vemos, é uma categoria que atribui aos diferentes episódios uma significação que transcende o particularismo factual. Há uma evidente dimensão retórica deste código, visto que, como demonstram os exemplos apresentados, ele era mobilizado em situações de conflito bastante concretos. Admitindo isto, compreendemos como as argumentações do bispo D. Pedro Fernandes e do padre Manuel da Nóbrega, anteriormente analisadas, estão indiretamente negociando o espaço da legitimidade cristã. A discordância em relação a quais práticas descaracterizariam a fé cristã, indicativa da diferença na maneira de entender a administração de sacramentos e a própria condição do indígena, desenvolve-se, contudo sob o mesmo código: o civilizado (cristão) que se torna selvagem.

Nas vereanças da vila, encontramos uma referência a brancos que bailam e bebem ao modo gentílico. Não há, como se vê, qualquer tipo de avaliação explícita da prática, que dificilmente teria lugar nesse formato de texto. Contudo, havendo ou não algum motivo por trás dessa resolução, o fato é que, servindo como argumentação, revela-nos que há uma identidade em questão:

[...] e mais requereo ho dito procuador do conselho que todo homem cristão branco que não seja negro de fora que se achar em aldea de negros foros ou cativos bebendo e bailando ao modo do dito jẽtio e suas merses lhes mãdasem e puzesem pregão e pena contra os tais ${ }^{263}$.

Em nossa interpretação, a mobilização deste código para se referir aos colonos leigos, nos exemplos que apresentamos, fundamenta-se em duas questões principais. A primeira é o papel retórico que este código cumpre no conflito envolvendo a escravidão indígena. Na correspondência, a partir desta construção, os jesuítas aparecem como os verdadeiros representantes da fé e da civilização, tanto em relação ao indígena quanto ao colono e o clero secular. A segunda questão é a prática da mancebia. Entendida não apenas como um costume gentílico, mas ainda como de caráter ritual, é um dos principais motivos que levavam os jesuítas a situarem colonos brancos no polo "selvagem" do processo civilizatório.

${ }^{263}$ ACVSP, 19/01/1583. 


\subsection{A mancebia}

A prática da mancebia ou do concubinato - palavras estas referentes a relações extraconjugais de tipos variados - foi bastante difundida no período colonial brasileiro, em todas as regiões. Diversas pesquisas abordaram essa questão, analisando os aspectos sociais, econômicos e religiosos envolvidos nesse tipo de união, concentrando-se em diferentes períodos e locais ${ }^{264}$. Interessa-nos aqui, mais especificamente, o aspecto religioso dessa prática, uma vez que os relatos jesuítas que analisamos interpretavam-na pelo viés do pecado, tendo como parâmetro o sacramento do Matrimônio ${ }^{265}$ e condenando-a insistentemente. Seguindo nossa proposta de trabalho, procuramos reconduzir as referências à mancebia em Santo André da Borda do Campo e São Paulo ao todo retórico das respectivas cartas. Para tanto, não consideramos essas narrativas um registro ou relatório do combate à mancebia pelos jesuítas: eram parte fundamental e atuante desse combate. Dessa forma, podemos fornecer um importante filtro crítico para a leitura dessa documentação, complementando as diversas leituras já realizadas nas pesquisas citadas, que se concentraram na análise de trechos específicos em conjunto com documentação de outra natureza.

Os historiadores valem-se frequentemente da correspondência jesuítica para investigar a prática da mancebia no século XVI, uma vez que dispõem de menos registros exteriores à Companhia para este século que para os períodos posteriores. Foi principalmente na leitura das cartas jesuíticas quinhentistas que Serafim Leite baseou sua análise das "Mancebias de brancos e mamelucos" em História da Companhia de Jesus no Brasil ${ }^{266}$. No texto de Serafim Leite, as cartas são tomadas como um registro objetivo do alcance e das modalidades da mancebia, assim como do combate a ela, realizado pelos missionários. Neste sentido, endossa a avaliação moralizante que baseia as descrições e a firmeza com que padres

\footnotetext{
${ }^{264}$ Cf., por exemplo: TORRES-LONDOÑO, Fernando. A outra família: Concubinato, Igreja e escândalo na Colônia. São Paulo: Edições Loyola, 1999; VAINFAS, Ronaldo. "Moralidades brasílicas: deleites sexuais e linguagem erótica na sociedade escravista". In: SOUZA, Laura de Mello e (org.). História da vida privada no Brasil, vol. 1: Cotidiano e vida privada na América portuguesa. São Paulo: Companhia das Letras, 1997, pp. 221-273; _. Trópico dos pecados: Moral, Sexualidade e Inquisição no Brasil. Rio de Janeiro: Campus, 1989; SILVA, Maria Beatriz Nizza da. Sistema de casamento no Brasil colonial. São Paulo: Editora da Universidade de São Paulo, 1984. Mariza Corrêa aponta a necessidade de contextualizar os estudos sobre estrutura familiar e relações interétnicas, evitando os modelos muito totalizantes, e de abordar as formas de relação familiar para além do modelo defendido como norma (no caso, o patriarcal): CORRÊA, Mariza. "Repensando a Família Patriarcal Brasileira". In: ALMEIDA, Maria Suely Kofcs et al. Colcha de Retalhos: Estudos sobre a Família no Brasil. São Paulo: Brasiliense, 1982, pp. 13-38.

${ }^{265}$ A grafia maiúscula de "Matrimônio" é aqui utilizada quando se refere especificamente ao sacramento, e não ao sentido mais amplo, que vem grafado com a minúscula.

${ }^{266}$ LEITE, Serafim, S. J. História da Companhia de Jesus no Brasil. Tomo II, século XVI - a obra. Lisboa; Rio de Janeiro: Livraria Portugalia; Civilização Brasileira, 1938, Capítulo IV, Livro Terceiro, pp. 361-90.
} 
e irmãos descreviam a própria batalha contra o dito pecado. $\mathrm{O}$ autor aponta, seguindo as afirmações dos missionários, as três medidas que estes propuseram para combatê-lo: "a vinda de homens honrados, já casados, com as suas mulheres; a vinda de mulheres brancas [...]; e o terceiro, mais difícil, porém mais cristão e civilizador: o casamento das índias com os brancos" 267 , medidas que tiveram, notadamente esta última, alcance limitado. Na apresentação das causas da grande incidência da mancebia, Serafim Leite elenca a adoção pelos colonos da poligamia indígena, a disposição moral ruim de parte dos portugueses adventícios, a disponibilidade das índias e até mesmo o clima $^{268}$. Com exceção desta última, para a qual indica ser tributário de Gilberto Freyre, as outras causas apontadas são abordadas com os mesmos parâmetros utilizados pelos missivistas. Entre as causas, estaria também a "conivência dalgum clero"269, questão levantada principalmente por Nóbrega, que colocaria os jesuítas como os legítimos defensores da moralidade, e não considerada em sua parcialidade argumentativa por Serafim Leite.

As pesquisas posteriores também utilizaram largamente a correspondência jesuítica para tratar do tema da mancebia, mas tiveram o cuidado de assinalar a subjetividade dessa documentação. Torres-Londoño, cuja pesquisa foca-se no século XVIII, utiliza as cartas para analisar o estabelecimento da mancebia dos portugueses com as índias durante o primeiro século de colonização, procurando, entretanto, problematizar a opinião nelas presente sobre a inclinação sexual das nativas, interpretando-a como uma "útil criação de portugueses e ocidentais", "carregada da misoginia européia" ${ }^{270}$. Nesta perspectiva, os relatos jesuíticos são relacionados, pelo autor, a uma mais ampla construção sobre o feminino, proveniente de ambientes religiosos e laicos europeus. A explicitação dessa interferência subjetiva na descrição dos nativos não deve nos levar, no entanto, a uma desconsideração da efetiva influência que os costumes sexuais e sociais das populações brasílicas tiveram na formação da sexualidade colonial. Deste aspecto se ocupam Ronaldo Vainfas ${ }^{271}$ e Maria Beatriz Nizza da Silva ${ }^{272}$, analisando a adoção de costumes indígenas por parte dos primeiros colonizadores, da qual os casos de Caramuru e João Ramalho seriam, segundo Vainfas, os mais representativos.

\footnotetext{
${ }^{267}$ LEITE, Serafim, S. J. História da Companhia de Jesus no Brasil. Tomo II, século XVI - a obra. Lisboa; Rio de Janeiro: Livraria Portugalia; Civilização Brasileira, 1938, Capítulo IV, Livro Terceiro, p. 372.

${ }^{268}$ Ibid., pp. 373-4.

${ }^{269}$ Ibid., p. 377.

${ }^{270}$ TORRES-LONDOÑO, Fernando. A outra família: Concubinato, Igreja e escândalo na Colônia. São Paulo: Edições Loyola, 1999, p. 35.

${ }^{271}$ VAINFAS, Ronaldo. "Moralidades brasílicas: deleites sexuais e linguagem erótica na sociedade escravista". In: SOUZA, Laura de Mello e (org.). História da vida privada no Brasil, vol. 1: Cotidiano e vida privada na América portuguesa. São Paulo: Companhia das Letras, 1997, pp. 231-2.

272 SILVA, Maria Beatriz Nizza da. Sistema de casamento no Brasil colonial. São Paulo: Editora da Universidade de São Paulo, 1984, especialmente pp. 36-8.
} 
A indicação nas cartas das uniões "segundo o costume da terra" fariam referência a essa adoção da prática poligâmica indígena, segundo a qual os homens que se destacassem em valentia e influência teriam mais mulheres. Mais do que uma simples adoção de práticas indígenas pelos portugueses, devido à carência de mulheres brancas, as prática da mancebia e da poligamia faziam parte do estabelecimento de alianças entre colonos e nativos ${ }^{273}$.

A referência dos missivistas à mancebia é constante em todo o período que tratamos, e assume, como veremos, um papel de destaque na descrição dos pecados dos colonos e no relato do trabalho ministerial dos missionários. O conceito de mancebia, no entanto, não é fechado e imutável. É necessário compreender o que os missionários queriam significar com sua utilização, uma vez que a definição do conceito é parte de um processo bastante longo, relacionado à delimitação do Matrimônio como único espaço válido e sacralizado, do ponto de vista da ortodoxia católica, para a união entre homem e mulher ${ }^{274}$. Nas cartas jesuíticas do Brasil quinhentista, predominou o uso dos termos "manceba" e "amancebados", ainda que não estivesse ausente o uso pontual da palavra "concubina", com o mesmo sentido ${ }^{275}$.

As palavras "concubinato", "mancebia" e "barregania" variaram em sua significação e uso ao longo do tempo. Na Idade Média Ibérica predominou o uso de barregania, significando a relação de união entre homem e mulher, com dependência econômica e ausência do laço matrimonial ${ }^{276}$. A legislação portuguesa dos séculos XVI e XVII manteve essa definição, considerando barregueiros "o homem e a mulher que dormiam juntos, sendo que a mulher era sustentada pelo homem sem que estivessem casados perante a Igreja"277. No século XVIII, essa relação passou a ser predominantemente denominada "concubinato", palavra que também se referia a contatos mais esporádicos. Torres-Londoño refaz a trajetória desse conceito desde a Antiguidade, mostrando como a acepção latina de concubinat - união permitida, mas sem os vínculos e direitos do matrimônio, devido à diferença social - foi transformando-se com o advento do cristianismo, tendo na obra de Santo Agostinho um

\footnotetext{
${ }^{273}$ MONTEIRO, John Manuel. Negros da Terra: índios e bandeirantes nas origens de São Paulo. São Paulo: Companhia das Letras, 1994, p. 34.

${ }^{274}$ Cf. VAINFAS, Ronaldo. Casamento, amor e desejo no ocidente cristão. São Paulo: Editora Ática, 1986, pp. 25-48; __ . Trópico dos pecados: Moral, Sexualidade e Inquisição no Brasil. Rio de Janeiro: Campus, 1989, pp. $70-5$.

${ }^{275}$ Cf., por exemplo, a carta do Irmão Pero Correia, enviada de S. Vicente a 10 de março de 1553 para o Padre Simão Rodrigues, na qual é utilizado o termo "concubina" para se referir às diversas escravas com que os homens casados se deitavam. O jesuíta não utiliza nas cartas os termos concubinato, mancebia ou amancebamento, adotando designações como "estava en pecado com um hombre", "vive en pecado mortal con una índia" ou "tenerlas [as índias] por mugeres". $M B I$, carta 60, pp. 433-448. Trata-se de tradução espanhola da carta original.

${ }^{276}$ TORRES-LONDOÑO, Fernando. A outra família: Concubinato, Igreja e escândalo na Colônia. São Paulo: Edições Loyola, 1999, pp. 25-7.

${ }^{277}$ Ibid., p. 27.
} 
marco para a definição do espaço legítimo do matrimônio ${ }^{278}$. Já a palavra "manceba", que também passaria no século XVIII a ser sinônimo de "barregã", poderia referir-se anteriormente à mulher envolvida em uma relação extraconjugal na qual era tida como de condição inferior ao homem em questão, seja por ser de uma camada social mais baixa, meretriz, ou mesmo escrava. No Brasil, o termo "mancebia" manteve, até o século XVII, essa ambiguidade no significado ${ }^{279}$. Ronaldo Vainfas, por sua vez, chama a atenção para a importância de situar melhor a relação entre matrimônio oficial e concubinato, destacando que, apesar dos casos de conjugalidade classificados como mancebia ou concubinato, em muitos outros os tratos ilícitos referiam-se a relações de natureza variada, fugazes ou duradouras, mas sem caráter conjugal e, dessa forma, seria preciso dimensionar melhor o papel da mancebia na sociedade colonial $^{280}$. Nesse sentido, o autor também percorre a trajetória do conceito de concubinato a partir da "tradição pagã greco-romana", destacando que "na História ocidental, o concubinato sempre foi, é certo, mais do que uma relação sexual episódica, mas não parece ter se identificado com qualquer forma de casamento" 281 .

Os pesquisadores têm apontado constantemente, para o século XVI, a relação entre mancebia e escravidão ${ }^{282}$. No que diz respeito a esse vínculo, a correspondência jesuítica já foi exaustivamente analisada pela historiografia. Dessa forma, não é preciso que nos detenhamos nas cartas para reafirmar o processo pelo qual a dominação dos senhores sobre as escravas se estendia também à sexualidade. No entanto, para compreender a que os jesuítas se referiam ao utilizar os conceitos de "manceba" e "amancebados", é necessário analisar as consequências terminológicas decorrentes desse vínculo entre mancebia e escravidão. Partindo da centralidade deste vínculo, a palavra "amancebamento", nesse período, serviria para designar os tratos ilícitos entre brancos e suas escravas e, assim sendo, o termo "manceba" guardaria parte do sentido ligado à condição social inferior da mulher em questão, como indicamos anteriormente. Nessa formulação, cumprem papel de destaque as primeiras cartas enviadas por Nóbrega ainda em 1549, ano de sua chegada ao Brasil, nas quais busca apresentar o estado geral da terra. Nesse conjunto, há um trecho de uma carta datada de 9 de

\footnotetext{
${ }^{278}$ TORRES-LONDOÑO, Fernando. A outra família: Concubinato, Igreja e escândalo na Colônia. São Paulo: Edições Loyola, 1999, pp. 21-30.

${ }^{279}$ Ibid., p. 27.

${ }^{280}$ VAINFAS, Ronaldo. "Moralidades brasílicas: deleites sexuais e linguagem erótica na sociedade escravista". In: SOUZA, Laura de Mello e (org.). História da vida privada no Brasil, vol. 1: Cotidiano e vida privada na América portuguesa. São Paulo: Companhia das Letras, 1997, p. 237.

${ }^{281}$ VAINFAS, Ronaldo, Trópico dos pecados: Moral, Sexualidade e Inquisição no Brasil. Rio de Janeiro: Campus, 1989, p. 72.

${ }^{282}$ Id., "Moralidades brasílicas", op. cit., pp. 230-4; TORRES-LONDOÑO, op. cit., pp. 31-46; SILVA, Maria Beatriz Nizza da. Sistema de casamento no Brasil colonial. São Paulo: Editora da Universidade de São Paulo, 1984, pp. 36-8.
} 
agosto que se tornou citação obrigatória para os historiadores que estudaram a mancebia na colônia: "Nesta terra há hum grande peccado, que hé terem os homens quasi todos suas negras por mancebas, e outras livres que pedem aos negros por molheres, segundo ho custume da terra, que hé terem muitas molheres"283.

Maria Beatriz Nizza da Silva aponta nesse trecho a distinção vocabular entre "mancebas" e "mulheres", referindo-se o primeiro termo à relação entre o senhor e a escrava, e o segundo à "união entre o branco e a índia livre segundo o costume da terra" ${ }^{284}$. Afirma a autora:

A interpenetração entre as práticas matrimoniais indígenas e as práticas transplantadas da metrópole antes da reformulação tridentina criava situações complicadas, que os padres descreviam, a maior parte dos casos, genericamente como situações de concubinato ou de mancebia. Por vezes, contudo, eles próprios distinguiam claramente entre uma situação de autêntica mancebia (o branco e suas escravas índias) de uma outra de união com índias livres "segundo o costume da terra" $" 285$.

Torres-Londoño, por sua vez, aponta o uso de "mancebia" no século XVI para "caracterizar os tratos que os colonos portugueses estabeleceram com as índias, negras e mestiças" 286 , na qual se destacaria igualmente o amancebamento entre senhor e escrava. Ambos, entretanto, indicam a polissemia do termo, já que também seria usado para classificar diversas outras “situações complicadas", ou relações apenas entre indígenas ${ }^{287}$. Consideramos importante, no entanto, esmiuçar mais essa polissemia, pois a separação entre um uso genérico, relativo a diversos tratos ilícitos, e um outro estrito, referente à relação entre senhores e escravas não parece corresponder aos critérios mais caros aos missionários jesuítas em seu ministério entre brancos e índios. A leitura da Informação dos Casamentos dos Índios do Brasil, escrita por Anchieta ${ }^{288}$, indica que a relação entre um uso mais estrito e um mais genérico está presente mesmo quando voltado apenas para a descrição dos indígenas. A utilização de "amancebados" também para indígenas batizados aparece em outras cartas, como na do próprio Anchieta, de $1562^{289}$; em duas do irmão António de Sá, a primeira

\footnotetext{
${ }^{283} M B I$, p. 119.

284 SILVA, Maria Beatriz Nizza da. Sistema de casamento no Brasil colonial. São Paulo: Editora da Universidade de São Paulo, 1984, p. 36.

${ }^{285}$ Ibid., p. 37.

286 TORRES-LONDOÑO, Fernando. A outra família: Concubinato, Igreja e escândalo na Colônia. São Paulo: Edições Loyola, 1999, p. 28.

${ }^{287}$ M. B. Nizza da Silva, por exemplo, aborda a diferença da classificação das relações indígenas entre mancebia ou casamento de acordo com o argumento de que a carta tratasse (op. cit., pp. 34-5).

288 ANCHIETA, José de, S.J. Cartas, Informações, Fragmentos Históricos e Sermões do Padre Joseph de Anchieta, S.J. (1554-1594). Rio de Janeiro: Civilização Brasileira, 1933, pp. 448-456.

${ }^{289} M B$ III, p. 455.
} 
enviada do Espírito Santo em $1559^{290}$ e a segunda, enviada de Pernambuco em $1563^{291}$, na qual utiliza "amancebados" para escravos batizados e não batizados; e na escrita em 1568 pelo padre Baltasar Fernandes, de São Vicente.

O trecho de Nóbrega anteriormente citado parece, dessa forma, ter uma preocupação mais descritiva que analítica. De fato, "ter por mulher" poderia ser utilizado também para descrever a situação de amancebamento entre senhor e escrava, como sugere o uso que lhe dá o irmão Pero Correia na carta escrita de São Vicente em março de 1553: "Era costumbre antiguo en esta tierra los hombres casados que tenían 20 y más esclavas y índias tenerlas todas por mugeres" 292 . Entre a pluralidade dos sentidos que fazem parte do uso desses termos, torna-se ainda mais importante contextualizar o uso que se lhes dá em cada carta. A partir daí, algumas distinções clareiam os critérios de combate a esse pecado movido pelos membros da Companhia. A utilização mais estrita do termo "amancebado" tem como referência a ausência do sacramento do Matrimônio, tanto para brancos quanto para índios. Portanto, quando os missionários descrevem o costume tão comum de os senhores terem suas negras por mancebas, como vimos, especificam com maiores detalhes. Quando usado de forma mais geral, correspondendo a "trato ilícito", seja o esporádico ou o continuado, ainda mantém o vínculo com o sacramento, mas com um valor descritivo menos preciso. Já a palavra "manceba" apresenta, na maioria das vezes, ainda que nas entrelinhas, uma qualificação inferiorizada daquela mulher específica e, neste sentido, é constante nas descrições dos senhores brancos amancebados com índias escravas. No entanto, como nos mostra a utilização de Anchieta, pode também descrever uma relação de uma cativa de guerra, índia ou mestiça, com um indígena ${ }^{293}$.

A recorrência do tema da mancebia na correspondência jesuítica indica, além da grande incidência da prática, o papel central que ela ocupa na relação dos missionários com os colonos. Como vimos, é constante na epistolografia jesuítica apresentar um estado geral das coisas, que poderia ser acompanhado ou não de algum exemplo representativo. Quando se apresenta o estado geral em que se encontram os colonos, a mancebia figura, na maioria das vezes, como principal acusação. As primeiras cartas enviadas da capitania de São Vicente que chegaram até nós - uma de Leonardo Nunes em fins de 1550, seguida de um conjunto de sete cartas escritas por ele e por irmãos, provavelmente todas em junho de 1551 - indicam já essa

\footnotetext{
${ }^{290} M B I I I$, p. 47.

${ }^{291} M B I V$, p. 37.

${ }^{292} M B I$, p. 438.

293 ANCHIETA, José de, S.J. Cartas, Informações, Fragmentos Históricos e Sermões do Padre Joseph de Anchieta, S.J. (1554-1594). Rio de Janeiro: Civilização Brasileira, 1933, p. 450.
} 
tendência ${ }^{294}$. Tomadas em conjunto, estas cartas exprimem o grande interesse que os inacianos tinham nos índios, fornecendo descrições e afirmando constantemente a boa disposição destes para o batismo; mas, por outro lado, revelam que grande parte do tempo era ainda dedicada ao trabalho com os brancos. Neste trabalho, a mancebia ocupava um papel de destaque.

Na carta de 1550, enviada por Leonardo Nunes aos padres e irmãos de Coimbra ${ }^{295}$, predomina o caráter edificante, com a inclusão de episódios consoladores - para usar o vocabulário da Companhia - na narrativa mais longa do trajeto que o padre realizou da Bahia até a Capitania de São Vicente, passando por Porto Seguro e Espírito Santo, com o objetivo de restituir à sua terra alguns índios injustamente cativos. Leonardo Nunes fornece uma descrição a respeito de cada uma das localidades em que passou, a qual intercala um estado geral das coisas com narrativas factuais do que realizou durante sua estadia. Sobre a capitania de São Vicente, escreve o missivista:

[...] todos quasi los habitadores destas três villas estavan en gravissimos peccados offuscados assí casados como solteros, y mucho más los sacerdotes, los començó de moyer y traer a tal confusión y sentimiento de sus peccados, que todos trabajavan por se apartar dellos, unos casándose con las mugeres y índias que tenian, otras echándolas fuera, y otros buscándole maridos, otros determinando de vivir castamente con sus mugeres, y todos con grandes espantos de sí, viendo su ceguedad y peligro en que estavan tanto tiempo avia, porque avia muchas almas que no avían sido confessadas treinta o quarenta años avia, y estavan en peccado mortal, y esto públicamente $^{296}$.

O relato consiste, como se vê, em uma contraposição entre o estado negativo em que se encontravam os colonos e o resultado positivo que a ação do jesuíta causou. É a mesma estrutura utilizada para descrever, um pouco antes, a situação da capitania do Espírito Santo: "En esta Capitania La mayor parte de la gente estava en pecado, y quiso nuestro Señor que con mi llegada se començassen a mover". "Mover" significava apartar-se de "pecado mortal", como os "dos hombres [que] se casaron com índias que tenían em casa" "297. A persistência do problema nos anos posteriores indica que esse "movimento" não se realizava com a intensidade apontada por Leonardo Nunes. Considerando o caráter subjetivo do relato, fica praticamente impossível recuperar se a admoestação do missionário causou um ímpeto inicial

\footnotetext{
${ }^{294} M B I$, cartas 18, 23, 24, 25, 26, 27, 28 e 29.

${ }^{295}$ Serafim Leite indica que a carta parece ter sido dirigida primitivamente ao padre Simão Rodrigues, por causa de uma indicação no corpo texto. Dessa forma, a destinação para os padres e irmãos de Coimbra poderia ser uma alteração do tradutor. Esta questão não afeta a análise, uma vez que a evocação de Simão Rodrigues poderia ser simplesmente indireta e na carta predomina o tom edificante assim como naquelas destinadas a padres e irmãos (MBI, p. 201).

${ }^{296} M B I$, p. 207.

${ }^{297} M B$ I, p. 203.
} 
nos colonos, que depois arrefeceu; se ele deixou-se levar por atitudes apenas exteriores; ou o quanto a necessidade de construir uma narrativa edificante condicionou as informações, mesmo que de forma não intencional. O que podemos apontar, de fato, é que a apresentação dos resultados positivos no combate à mancebia cumpria na estrutura retórica dessas cartas o papel de edificar espiritualmente, além de divulgar, para dentro e fora da Companhia ${ }^{298}$, os bons frutos da presença da ordem no Brasil.

Alguns casamentos entre brancos e índias amancebados parecem ter de fato ocorrido, como aponta a próxima carta do próprio Leonardo Nunes, de junho de 1551, na qual esse resultado positivo traduz-se em termos numéricos: "Algunos hombres de los que estavão amancebados com índias se casavan con ellas, que serán 15 ó 16 y aora andam otros 7 ó 8 para hazer lo mismo"299. Mesmo ressaltando que havia "muchos muy endurecidos", o foco direciona-se aos bons resultados, sendo também essa referência parte de um balanço positivo mais geral, de caráter edificante, que interpreta e comunica esses sucessos pontuais como um movimento em direção à piedade. Nesse balanço sobre o trabalho com os colonos, trata ainda de temas como o fim de "los saltos que los christianos hazião en los gentiles de la costa"; "el comer carne" na quaresma, que "es muy emendado"; o "darles [aos índios] armas, que era muy general hazerlo" - e então se corrigia -; e os juramentos, que também estariam "muy emendados, porque jurão poco y se reprehenden unos a otros quando juran"300 . A seguir, o missionário passa a tratar dos indígenas. O que temos, portanto, é um elenco dos problemas identificados nos colonos de São Vicente, todos sendo resolvidos pelo trabalho da Companhia, sem deixar de destacar que "era tan grande la perditión de las animas, que aún ay mucho que hazer" ${ }^{301}$. Este tom otimista seria bastante frequente nas cartas edificantes dos primeiros anos, e podemos encontrá-lo de forma semelhante nas primeiras cartas do Padre Manuel da Nóbrega ${ }^{302}$.

No trecho anteriormente transcrito, da carta enviada em 1550 por Leonardo Nunes, não se observa, nem marginalmente, referência a resistências por parte dos colonos, como apareceria na segunda, já que o missivista utiliza o absoluto "todos" para mostrar a intensidade do movimento piedoso de afastamento da mancebia. Encontramos essa indicação

\footnotetext{
${ }^{298}$ Lembrando que essa carta circulou em tradução italiana nas coletâneas impressas em Roma e Veneza (MB I, p. 201).

${ }^{302}$ Cf., por exemplo, trecho da carta de 9 de agosto de 1549: “[...] e huns se casão com algumas molheres se se achão, outros com has mesmas negras, e outros pedem tempo para venderem as negras, ou se casarem. De maneira que todos, gloria ao Senhor, se poem em algum bom meo". A seguir relata o que seria a única exceção (MB I, p. 120, grifo nosso).
} 
somente mais ao final da carta $^{303}$, quando o padre apresenta um relato de suas próprias atividades. Nessa espécie de "relatório" individual, têm menos destaque as atividades em concreto do que a demonstração de prudência e alinhamento com a postura ministerial característica da Companhia, dando origem a formulações mais abstratas e vagas, como: “ejercitándome em otras obras pías, buscando en todo la salvación de las animas" lembrando que a Companhia entendia seu ministério justamente como ajuda de almas. Continua o autor: "Y no con poco trabajo por ser solo [único padre, os outros em São Vicente nesse momento eram irmãos], y por la persecución de algunos deste puerto, porque de uma parte fui persiguido de algunos amancebados por los querer apartar del pecado", tratando mais das condições difíceis de seu trabalho e, portanto, de sua firmeza, que da situação dos colonos. A referência a essa "perseguição" sofrida por Leonardo Nunes em São Vicente, que desponta discretamente no relato, é semelhante à narração do episódio em que João Ramalho e seus filhos teriam-no agredido em Piratininga pelo mesmo motivo, feita pelos irmãos Pero Correia e Diogo Jácome, em $1551^{304}$.

O mesmo trecho permite-nos ainda identificar outros elementos da prática da mancebia e da forma como os jesuítas interpretavam-na e combatiam-na. Primeiramente, é bastante representativo do que analisamos anteriormente em relação às problemáticas terminológicas e do que estavam os inacianos combatendo de fato, uma vez que trata dos "gravíssimos peccados" ${ }^{305}$, sem utilizar nenhum conceito específico, como "amancebamento" ou "manceba". Ao descrever como os colonos estavam se "apartando" dos ditos pecados, fornece-nos especularmente um elenco dos comportamentos que estavam sendo combatidos. Na passagem “unos [estavam] casándose con las mugeres y índias que tenían” ou “echándolas fuera", podemos ver uma condenação das relações com coabitação, como sugere a solução de lançá-las fora. Por outro lado, o par "mugeres y índias" poderia significar "índias livres e escravas”, por analogia, ou simplesmente mulheres mestiças e índias. Qualquer que seja o sentido que lhes deu o missivista, podemos ver que a condenação das relações com escravas e não escravas apareciam correlacionadas ou, ao menos, condenadas no mesmo nível. A seguir, com a passagem "determinando de vivir castamente con sus mugeres", podemos observar a condenação dos tratos ilícitos de qualquer natureza, em uma construção que poderia incluir as relações episódicas com as escravas - provavelmente a mais frequente -, assim como qualquer tipo de adultério.

\footnotetext{
${ }^{303} M B I$, p. 209-10, para todo o trecho a seguir.

${ }^{304} M B I$, p. 222 e 243.

${ }^{305}$ MB I, p. 209-10, para todo o parágrafo.
} 
As cartas provenientes de São Vicente de que tratamos descrevem a mancebia como corrente em toda a capitania, uma vez que estão, como dissemos, apresentando seu estado geral. Ainda que grande parte das descrições refira-se especificamente à vila de São Vicente, não há, nessas primeiras cartas, uma diferenciação, quanto a esse pecado, entre os povoadores do Campo e da costa. Podemos, de acordo com essa tendência, encontrar uma utilização do caso de João Ramalho, povoador do Campo, para descrever exemplarmente o que seria a situação generalizada dos costumes dos colonos em toda a capitania, como faz o irmão Diogo Jácome ${ }^{306}$.

\subsection{Administração de sacramentos}

A relação dos colonos do planalto paulista com a Igreja católica, no que tange à liturgia, aos sacramentos ou à malha paroquial, dificilmente é analisada por meio de um tratamento sistemático das informações disponíveis. Selecionando uma ou outra alusão documental, conclui-se, às vezes apressadamente, que os moradores da região estavam afastados da comunhão da Igreja ou, por outro lado, que tudo corria na mais perfeita normalidade. $\mathrm{O}$ que sabemos a respeito deste tema está profundamente marcado pelo que veicularam os textos jesuíticos. É sobre esse problema que nos debruçaremos no presente tópico.

O período de que nos ocupamos é caracterizado pela exclusividade jesuítica no planalto. Os padres da Companhia eram os únicos a quem os colonos podiam recorrer para receber os sacramentos. Dessa maneira, entender a relação dos colonos com a prática ministerial jesuítica é, em larga medida, entender sua relação institucional com a Igreja. É necessário, contudo, esclarecer alguns pontos da relação de Santo André da Borda do Campo e São Paulo com a administração eclesiástica presente na costa vicentina.

Nosso objetivo não é apresentar um quadro descritivo da atividade pastoral da Companhia junto aos colonos, como no trabalho até hoje mais completo sobre o tema, realizado pelo padre Serafim Leite ${ }^{307}$. Temos buscado demonstrar, com nossa análise, os problemas que a natureza da documentação coloca a uma reconstrução factual tal qual a

\footnotetext{
${ }^{306} M B I$, p. 243.

${ }^{307}$ LEITE, Serafim, S. J. História da Companhia de Jesus no Brasil. Lisboa: Livraria Portugália; Rio de Janeiro: Civilização Brasileira, 1938, Tomo II, Livro III, Capítulo 1, pp. 269-98.
} 
desenvolvida na obra do historiador jesuíta. Propomos aqui uma análise da maneira como a correspondência apresenta o tema da administração de sacramentos aos colonos, dialogando criticamente com o viés institucional dos documentos e cotejando as informações com as fornecidas pelas atas da Câmara da vila de São Paulo.

O sacramento do Matrimônio, um dos que aparecem mais frequentemente nas cartas, foi já analisado no tópico anterior, em sua relação com a prática da mancebia e o combate que lhe moveram os missionários jesuítas. Consideramos mais conveniente tratar separadamente esse sacramento pela grande importância do tema na historiografia e pelas questões específicas que a descrição da mancebia apresenta nessa documentação, como vimos. O enfoque do presente tópico na confissão e comunhão justifica-se por seu destaque nas cartas, fruto da importância a elas atribuída no ministério da Companhia de Jesus.

A administração de sacramentos ocupava um lugar importante no ministério jesuíta, ainda que houvesse uma ênfase maior nos ministérios da palavra e obras de misericórdia ${ }^{308}$. $\mathrm{O}$ Instituto da Companhia determinava que os membros não deveriam assumir a condição de pastores de paróquias. No entanto, eram autorizados a administrar os sacramentos permitidos aos simples sacerdotes, o que excluía a Confirmação e as Ordens, reservados aos bispos. Entendiam os inacianos que faria parte de seu ministério administrar a Eucaristia e a Penitência ordinariamente, mas o Batismo, o Matrimônio e a Extrema-unção somente em ausência de párocos ${ }^{309}$.

O sacramento da Penitência, que "requeria a confissão dos próprios pecados", adquiriu primazia em relação aos demais no ministério jesuíta ${ }^{310}$. Inácio de Loyola foi defensor da prática frequente da confissão, bem como da recepção mais frequente da Eucaristia. A necessidade da confissão para obter o perdão dos pecados era já defendida por teólogos medievais, e a prática crescia em importância no século XVI, sendo comum o uso de manuais de confissão ${ }^{311}$. Os jesuítas deram particular ênfase ao aspecto consolador da confissão, vista como uma oportunidade de orientação, advertência e conforto para o penitente ${ }^{312}$. Este caráter consolador do sacramento é bastante presente nos relatos epistolares do Brasil.

\footnotetext{
308 O’MALLEY, John W. Os primeiros jesuítas. Tradução Domingos Armando Donida. São Leopoldo, RS: Editora UNISINOS; Bauru, SP: EDUSC, 2004, p.211.

${ }^{309}$ Ibid., pp. 211-2.

${ }^{310}$ Ibid., pp. 140-1;

311 Ibid., p. 214; EISENBERG, José. As missões jesuíticas e o Pensamento político moderno: Encontros culturais, aventuras teóricas. Belo Horizonte: Ed. UFMG, 2000, p. 39.

312 O’MALLEY, op. cit., pp. 220-2.
} 
Em relação ao trabalho missionário com os indígenas brasileiros, as narrativas epistolares dão grande destaque, ao lado da Penitência e da Eucaristia, aos sacramentos do Batismo e do Matrimônio. Este conjunto estava na base da estratégia missionária de conversão do gentio. Relatando as atividades dos jesuítas na Bahia, José de Anchieta assim descreve o trabalho com índios e africanos das fazendas, engenhos e paróquias:

O metodo que se adota nestas missões, é ensinara e explicar a doutrina cristã aos Indios e Africanos reunidos em um lugar, batizar, ouvir-lhes as confissões, separá-los das concubinas e sujeitá-los ás leis do matrimonio: o que nesta provincia é trabalho quotidiano, necessario e utilissimo á salvação das almas ${ }^{313}$.

Em relação às povoações dos portugueses, como mencionamos anteriormente, os jesuítas poderiam, onde não houvesse presença de párocos, suprir as necessidades pastorais da população, ainda que se buscasse evitar essa situação. O caso das vilas de Santo André da Borda do Campo e de São Paulo de Piratininga situa-se justamente nessa condição. Entretanto, visto que raramente essa atividade é mencionada na correspondência, além de ser abordada a partir de condicionamentos institucionais e formais particulares, analisados ao longo da dissertação, é fundamental que não se tome arbitrariamente trechos singulares como norma cotidiana. Antes que descrever o cotidiano pastoral no planalto paulista, interessa-nos identificar alguns dos elementos envolvidos na relação dos jesuítas e colonos com os sacramentos, as cerimônias e a estrutura eclesiástica.

Afonso Taunay considera que, no período de exclusividade pastoral da Companhia na vila de São Paulo, não ficavam os moradores desassistidos, posto que "no Colégio de Piratininga, numerosos sacerdotes jesuítas havia, que facilmente davam conta do serviço da restrita cura de almas”314. Esta afirmação, contudo, não é desenvolvida em linhas menos generalistas e, mesmo sem apresentar a sua fundamentação, podemos conjecturar se o célebre historiador não estaria ecoando a maneira vaga com que as cartas jesuíticas apresentaram o tema. Há alguns questionamentos de importância a serem colocados a uma afirmativa como esta.

Em primeiro lugar, o que poderia significar "dar conta" em cada uma das perspectivas envolvidas (jesuítas e colonos)? Se pensarmos na dimensão política (no sentido do viver em uma comunidade urbana) de atividades como sepultamento, Batismo,

\footnotetext{
313 ANCHIETA, José de, S.J. Cartas, Informações, Fragmentos Históricos e Sermões do Padre Joseph de Anchieta, S.J. (1554-1594). Rio de Janeiro: Civilização Brasileira, 1933, p. 399.

314 TAUNAY, Afonso de E. São Paulo nos primeiros anos (1554-1601): ensaio de reconstituição social; São Paulo no Século XVI: história da vila piratiningana. Coordenação de Paula Porta. São Paulo: Paz e Terra, 2003 [1920, 1921], p. 58.
} 
Matrimônio, festas e procissões, missas etc., pode-se tentar averiguar se os jesuítas atendiam suficientemente a estas necessidades da comunidade. Todavia, mesmo cumprindo estas tarefas, não é dessa maneira que os jesuítas entendiam seu próprio ministério, ao qual estas atividades representavam um empecilho, e certamente não é a elas que aludem em sua correspondência quando afirmam fazer "bom fruto" com os portugueses. Em segundo lugar, é necessário questionar como a frequência à igreja da Companhia se relacionaria à dinâmica de ocupação espacial da região, visto como as atividades agropastoris afastavam os portugueses do núcleo murado, preferencialmente voltado às atividades administrativas e cerimônias religiosas, ainda que o predomínio das atividades agrárias causasse certa indefinição quanto aos limites físicos entre o meio rural e o propriamente urbano ${ }^{315}$.

Serafim Leite, tratando do Brasil em conjunto, também destaca o zelo ministerial dos jesuítas para com a população branca, tanto de maneira geral quanto especificamente nos lugares em que não havia pároco. Porém, também em seu texto, essa afirmação se limita a reafirmar a maneira vaga com que os missionários relatavam sua própria atividade entre os colonos. Nesse sentido, afirma: "Os Padres confessavam todo o género de pessoas. Mas de modo particular os humildes, índios e negros. Não descuravam contudo os brancos, quando o pediam" 316 . O autor utiliza uma citação que indica o bom resultado da atividade ministerial entre os portugueses, isolada de seu contexto narrativo, para ratificar a própria avaliação da carta.

O fruto entre os próprios Portugueses fêz-se sentir. Vicente Rodrigues, escrevendo em 1552, diz que os "brancos ganham o jubileu com muita devoção". Havia práticas à sexta-feira, "onde vem muita gente e o Governador com tôda a gente principal, nos quais há muita emenda na vida e exemplo: não juram, e se escapa alguma, olham para trás, para ver se ouvem" $" 317$.

Não faltam, como vimos no capítulo anterior, referências contrárias, isto é, do pouco fruto obtido com os portugueses. No texto de Serafim Leite, este tema é incluído na descrição dos vícios dos colonos, aos quais não cediam os inacianos. Dessa forma, na obra apologética

\footnotetext{
${ }^{315}$ MORSE, Richard M. Formação histórica de São Paulo (de comunidade à metrópole). São Paulo: Difusão Européia do Livro, 1970 [1954], p. 30; SILVA, Maria Beatriz Nizza da (org.) et al. História de São Paulo colonial. São Paulo: Editora UNESP, 2009, pp. 35-6. Sérgio Buarque de Holanda analisa o processo da ocupação e exploração de terras no planalto desde o final do século XVI, apontando também para o século posterior a ausência de missa e doutrina em função do afastamento do núcleo urbano ("Movimentos da população em São Paulo em meados do século XVIII (sic)", Revista do IEB, n.1, 1966, pp. 55-111).

${ }^{316}$ LEITE, Serafim, S. J. História da Companhia de Jesus no Brasil, tomo II. Lisboa: Livraria Portugália; Rio de Janeiro: Civilização Brasileira, 1938, p. 279.

${ }^{317}$ Ibid., p. 270.
} 
do autor, o tema da administração de sacramentos entre os portugueses foca-se nos bons resultados ou na diligência dos missionários em combater os vícios ${ }^{318}$.

As alusões epistolares à atividade pastoral entre os habitantes da vila de São Paulo estão centradas na indicação de não possuírem pároco próprio. No documento intitulado "Memorial das cousas que o P. ${ }^{\mathrm{e}}$ Gregorio Sarraõ ha propuesto a N. P. ${ }^{\mathrm{e}}$ Geral cõ la respuesta de su Paternidad. año .76."319, que pede esclarecimento acerca de diversas questões envolvendo o ministério jesuíta no Brasil, aponta-se o seguinte em relação à vila de São Paulo: "En Piratininga esta una uilla de blancos, y por no tener cura, los P. es exercitan este officio, y por esta cauza se entierran en nra' Iglesia los de aquella Villa"320. O documento é um conjunto de dúvidas referentes à maneira de proceder no Brasil, daí a objetividade do tratamento e a ausência de mais informações. A resposta indicava a necessidade de providenciarem pároco, à qual se acrescenta à margem, em data posterior: "ja o te"”. Destacamos ainda o interessante pormenor de que, dentre todas as atividades que se poderia incluir para indicar o caráter praticamente paroquial assumido pela igreja, Gregório Serrão cita o sepultamento na igreja, que mais destacaria, em seu entender, esse aspecto.

No interior da estrutura formal e do repertório temático das cartas regulares não havia muito espaço para o cotidiano praticamente paroquial do atendimento jesuíta a moradores de uma pequena vila sem pároco. Algumas indicações a respeito da frequência e da maneira com que se atendia aos colonos de São Paulo são fornecidas por outras modalidades de escritos, também jesuíticos, como as informações e os relatos de viagens, construídos a partir de critérios diversos. Em uma Informação da Provincia do Brasil para nosso Padre de 1585, atribuída a Anchieta, afirma-se que a vila de São Paulo "não tem cura nem ha outros sacerdotes senão os nossos, nem os Portugueses os querem aceitar” e, dessa forma, os jesuítas eram "como curas dos Portugueses e lhes administram todos os sacramentos, são mui amados de todos e como pais daquela gente"321. Já o relato de viagem de Fernão Cardim, dá a entender que os moradores compareciam regularmente à missa do domingo, além de acrescentar uma listagem das atividades realizadas.

\footnotetext{
${ }^{318}$ LEITE, Serafim, S. J. História da Companhia de Jesus no Brasil, tomo II. Lisboa: Livraria Portugália; Rio de Janeiro: Civilização Brasileira, 1938, p. 280.

319 ARSI, Bras. 2, ff. 24-6. O título está riscado, e acima se atribui em anotação a proposição do memorial ao provincial Inácio Tolosa.

${ }^{320}$ Ibid., 24. O trecho está transcrito em grafia atualizada em LEITE, Serafim, S. J. História da Companhia de Jesus no Brasil. Lisboa: Livraria Portugália; Rio de Janeiro: Civilização Brasileira, 1938, Tomo I, p. 313, mas recorremos ao original para compreender seu contexto narrativo. Mantivemos a grafia do documento para seguir o padrão adotado no restante do trabalho.

${ }^{321}$ ANCHIETA, José de, S.J. Cartas, Informações, Fragmentos Históricos e Sermões do Padre Joseph de Anchieta, S.J. (1554-1594). Rio de Janeiro: Civilização Brasileira, 1933, p. 423-4.
} 
Vão aos domingos á igreja com roupões ou berneos de cacheira sem capa. A villa [...] não tem cura nem outros sacerdotes senão os da Companhia, aos quaes têm grande amor e respeito, e por nenhum modo querem aceitar cura. Os padres os casam, baptisam, lhes dizem as missas cantadas, fazem as procissões, e ministram todos os sacramentos, e tudo por sua caridade: não tem outra igreja na villa senão a nossa. Os moradores sustentam seis ou sete dos nossos, com suas esmolas com grande abundancia ${ }^{322}$.

Tomando a descrição inteira de Cardim acerca da vila de São Paulo, fica claro o predomínio do trabalho com os portugueses da vila em relação aos índios aldeados em Pinheiros e São Miguel. A função praticamente paroquial da igreja jesuítica pode ser visualizada também, de forma indireta, nas atas da Câmara da vila de São Paulo:

Aos coatro dias do mes de abrill de mill e quinhentos e setenta e sinquo anos as portas da igreja desta villa de san paullo o sair da misa estando junto a mor parte do povo desta villa hi $\mathrm{p}^{\mathrm{r}}$ pero fr̃z $\mathrm{p}^{\mathrm{r}} \operatorname{tr}^{\mathrm{o}}$ deste cõselho foi llancado preguão em alltas vozes ẽ q apreguoava o q $\mathrm{q}^{\sim}$ os senhores vreadores tinhão mandado $\mathrm{p}^{\mathrm{r}}$ termos fazer no llivro da camara ${ }^{323}$.

A referência à "igreja desta villa", justamente por consistir aqui em uma simples indicação técnica do pregão, revela o entendimento mais prosaico que se poderia ter da relação dos moradores com a igreja da Companhia. Sequer é mencionado o fato de se tratar da igreja dos jesuítas, irrelevante para o que se registrava. A igreja e a missa aparecem no trecho com a naturalidade do fato cotidiano, raramente visualizada nas referências jesuíticas em relação às atividades com os colonos nesta vila. A regularidade da presença dos moradores na missa está indicada não apenas por nessa ocasião estar ali junta a "mor parte do povo desta villa", mas pela própria frequência das indicações de que se tratava de lugar ordinário para se apregoar as posturas da Câmara ${ }^{324}$, sem considerar ainda os casos em que não se indica o local do pregão, que poderia ser o mesmo. Em uma ocasião, essa regularidade vem explícita: “[...] ao domingo ao sair da igreja como he custume nesta dita vila lanso diguo apreguoarão as posturas" 325 .

Há um problema, contudo, na constatação dessa regularidade semanal de comparecimento às missas. A dinâmica de ocupação espacial da região no período, com o predomínio da vida rural e o núcleo urbano voltado preferencialmente às atividades

\footnotetext{
${ }^{322}$ CARDIM, Fernão. Tratados da terra e gente do Brasil. Introduções e notas de Baptista Caetano, Capistrano de Abreu e Rodolpho Garcia. Rio de Janeiro: J. Leite \& Cia., 1925, p. 356.

${ }^{323}$ ACVSP, 04/04/1575.

${ }^{324}$ Além da expressão "ao sair da misa", presentes também nas atas de 07/05/1576; 22/09/1576 e 10/04/1588, utiliza-se também "no adro da igreja desta vila" (02/04/1580), "a frente da igreija" (23/05/1580) e "ao sair da higreja" (21/10/1584).

${ }^{325}$ ACVSP, 06/10/1583. A afirmação também é feita na ata de 01/12/1583.
} 
administrativas e religiosas ${ }^{326}$, influenciou a regularidade da frequência à igreja por parte dos moradores que se estabeleciam em locais mais afastados: “[...] os ditos moradores por rezam de as não poderem aproveitar vam lavrar daqui tres e quatro legoas de $\mathrm{q}^{\sim}$ os ditos moradores resebem muita perda outrosim por rezam de lavrarem logem deixam de vir algŭas vezes de virem a misa [...]"327. Depreende-se da informação que as dificuldades materiais influenciavam no cotidiano religioso e, ao mesmo tempo, que a presença nas cerimônias religiosas era alvo de atenção e controle pelos oficiais da Câmara.

Nesse sentido, também a presença nas procissões era controlada, podendo levar à cobrança de multas:

[...] loguo na dita camara requereo o perqurador $\mathrm{q}^{\sim}$ faltaram na prisiam de santa sabel a marquos fr̂zo velho e marquos fr̂z o moso e joam fr̂z filho de joam francisco digo joam ramalho $\mathrm{q}^{\sim}$ estes não viherao a prisiam $\mathrm{q}^{\sim}$ os condenasem nas pena $\mathrm{q}^{\sim}$ el rei da os quais loguo os condenarão a cada hŭ em dozentos res e mandarão pasar mãdado pera serẽ penhorados $[\ldots]^{328}$.

Durante o período em que a igreja da Companhia de Jesus funcionou como igreja "desta villa" e os jesuítas eram "como curas dos portugueses", os moradores de São Paulo gozavam de relativa regularidade em relação à administração dos sacramentos e celebrações, malgrado o caráter fragmentário das informações deixe algumas questões em aberto, como indicamos. Todavia, o período posterior à transferência de Santo André da Borda do Campo para junto do colégio de Piratininga, em 1560, representa um momento bastante diverso na história deste povoado. Além do afluxo dos moradores de Santo André, a população indígena reunida em torno do colégio estabelecia-se nos aldeamentos de Pinheiros e São Miguel ${ }^{329}$, transformando efetivamente o povoado de um núcleo predominantemente indígena em uma vila de portugueses.

Antes da transferência de Santo André da Borda do Campo para o sítio do colégio, e antes mesmo da fundação da casa de Piratininga, qual era a situação destes colonos e mamelucos do Campo? Em relação ao período de convivência entre a vila de Santo André e a casa, depois colégio, de Piratininga, indica-se também a assistência dos jesuítas, a partir de uma alusão rápida de Anchieta. Afirma Serafim Leite:

A vila de Santo André não teve pároco nem padre algum. Depois da fundação de S. Paulo, iam lá os Jesuítas aos domingos e dias santos.

\footnotetext{
${ }^{326}$ MORSE, Richard M. Formação histórica de São Paulo (de comunidade à metrópole). São Paulo: Difusão Européia do Livro, 1970 [1954], p. 30.

327 ACVSP, 27/02/1580.

${ }^{328}$ ACVSP, 16/07/1580.

${ }^{329}$ PETRONE, Pasquale. Aldeamentos paulistas. São Paulo: Edusp, 1995, p. 114.
} 
Celebravam missa, administravam os sacramentos, prègavam aos brancos, doutrinavam os Índios ${ }^{330}$.

Considerando-se, todavia, que, mesmo com os moradores estabelecidos em São Paulo, a dinâmica de ocupação do espaço criava dificuldades para o comparecimento semanal à missa, podemos questionar se, com a vila distante e os moradores espalhados pelas fazendas, a frequência era grande. De qualquer maneira, há uma questão mais importante. Os campos de Piratininga estavam sob a jurisdição do padre Simão de Lucena, vigário de São Vicente $^{331}$. Não há menção a contatos frequentes entre o vigário e a população de Serra Acima mas, ao que parece, a ideia de isolamento também condicionou essa conclusão. Há, por exemplo, uma carta do irmão Pero Correia que narra o episódio em que o "alguazil [meirinho] de los clérigos", tomou uma escrava da índia amancebada com Ramalho (Bartira) por "estar tanto tiempo en aquel y en otros pecados"332. Não está explicitado se João Ramalho e sua mulher estavam no litoral, ou se o "alguazil" subiu ao planalto. Em qualquer uma das possibilidades, há efetivamente contato. Levando em conta o quanto discutimos rapidamente acerca da ideia de isolamento, consideramos lícito questionar se não havia algum tipo de contato esporádico com o vigário de São Vicente antes de os jesuítas assumirem a cura espiritual dos colonos.

Muito do que se escreveu acerca da situação do colono do planalto no que tange à administração eclesiástica baseia-se na primeira carta de São Vicente, enviada por Leonardo Nunes em novembro de $1550^{333}$. Trata-se de uma carta importante para vários dos temas que tratamos ao longo da dissertação.

Ela se inicia por um exordium que, além das tradicionais fórmulas de humildade e obediência (benevolentiae captatio) pede que se "encomiende a Dios esta perdida gentilidad", destacando desde o início o fundamento da atividade missionária. Ainda como parte do exordium, resume o assunto das cartas anteriores: o pecado "muy arraygado y malo de arrancar" que era ter muitos índios injustamente cativos. Segue-se um relato de suas atividades no Espírito Santo e em São Vicente. Os dois relatos que apresenta destacam o grande fruto alcançado nas populações dos dois locais devido à sua presença. Descrevendo os bons frutos, apresenta indiretamente em que entendia constituir o ministério jesuíta: confissão, pregações, pacificação de conflitos, doutrina para escravos e portugueses. A descrição dos

\footnotetext{
${ }^{330}$ LEITE, Serafim, S. J. História da Companhia de Jesus no Brasil, tomos I. Lisboa: Livraria Portugália; Rio de Janeiro: Civilização Brasileira, 1938, p. 282.

${ }^{331}$ KUHNEN, Alceu. As origens da Igreja no Brasil: 1500 a 1552. Bauru, SP: EDUSC, 2005, 443.

${ }^{332} M B I$, pp. 435-6.

${ }^{333} M B I$, carta 18, pp. 200-10, para todas as citações a seguir.
} 
bons frutos alcançados contrapõe a sua própria atividade à do vigário local, que aparece como pouco zeloso de suas tarefas:

Continuavam con grandes desseos la doctrina y trabajavan mucho por la aprender, y dizían unos a otros: "Este es el verdadero que Dios manda, pues que no busca interés, sino enseñar a todos de balde las cosas de Dios" [...] Y quando la postreta noche en que me avía de despedir dellos vino, encomendéles que siempre perseverassen como lo avían hasta alli hecho, que el Padre vicario los enseñaría como yo, porque me lo tenía assí prometido.

O padre Leonardo Nunes constrói assim uma "apologia" do modo de proceder jesuíta, de como eles entendiam o próprio ministério e as vantagens em relação aos demais. Em relação ao pecado da mancebia, indica também o bom fruto que realizava e a condição de amancebado também dos sacerdotes. A seguir, descreve sua ida ao Campo, na passagem que se tonou emblemática:

Aquí me dixeron que en el Campo quatorze o quinze leguas daqui, entre los Indios estava alguna gente christiana derramada, y passávase el año sin oyr missa y sin se confessar, y andavam en una vida de salvajes. Viendo esto determiné de yr allá, tanto por dar remedio a estos christianos como por verme con estos gentiles, los quales están más apartados de los christianos que todas las otras Capitanías. [...]

Y yendo, en la postrera jornada topamos un mancebo con unas cartas para mí, que me estavan esperando, porque ya tenían nuevas que yo desseava de les yr a ver. Trabajé mucho con los christianos que allé derramados en aquel lugar entre los Indios, que se tornassen a las villas entre los christianos, en lo qual yo los hallé muy duros, mas en fin acabé com ellos que se ayuntassen todos en un lugar y hiziessen una hermita y buscassen algún Padre que les dixesse missa y confessasse. Pusiéronlo luego por obra y tomaron luego campo para la iglesia. Gasté dos o tres días con ellos, y confessé algunos y diles el Sanctissimo Sacramento.

Después desto nos fuimos dar con los Indios a sus aldeas que estavan quatro o cinco leguas day. [...] También hallé allí algunos hombres blancos, y acabé con ellos que se tornassen a los christianos.

Destacamos novamente aqui o que afirmamos anteriormente a respeito do isolamento. O "mancebo", que chega com umas cartas por saber de sua intenção de lá ir, não parece corroborar muito a ideia de uma região isolada. Há, por outro lado, vários questionamentos importantes a colocarmos a esse trecho.

Em primeiro lugar, o que poderíamos entender por "gente christiana derramada"? O sentido mais rapidamente identificável é o de não estarem juntos em uma vila, já que com os cristãos "derramados" ele trabalhou para que tornassem às vilas entre os cristãos. Pela dificuldade em fazê-los tornar à costa, fez com que "se ayuntassen" e convenceu-os a fazer uma ermida e buscar padre para rezar missa e confessar. Dessa forma, o que lhes falta é a 
instituição política (vila) e a religiosa (igreja e padre). Ao que parece, não viviam esses primeiros "christãos" na aldeia, já que é somente após permanecer três dias com eles que foram encontrar os índios em suas aldeias, onde também havia cristãos. Podemos cogitar a hipótese de que estarem derramados signifique que viviam em fazendas espalhadas pela região, sem uma vila em que se oficiassem as cerimônias religiosas e se dispusesse das instituições políticas. É apenas uma hipótese, mas em acordo com a tendência com que vai se desenvolver a ocupação na região, mesmo após a fundação da vila de Santo André.

Por fim, porque Leonardo Nunes considera que esses cristãos viviam "entre los Indios", se as aldeias estavam em outro lugar? E porque considerava os índios "más apartados de los christianos que todas las otras Capitanías", se havia cristãos vivendo entre eles? Seria apenas uma questão quantitativa? Se considerarmos, contudo, as categorias que o padre utiliza, podemos propor outra hipótese. O "viver entre índios" ou "entre cristãos" poderia referir-se à condição, antes que a uma referência à presença de um e de outro. Seria a ausência ou presença da organização política, das celebrações religiosas e dos sacramentos que definiria o que é viver entre índios ou entre cristãos. Vê-se então que Leonardo Nunes considerava como critérios para se classificar o que seria uma "vida de salvajes" justamente aqueles elemento que se procuraram incutir aos indígenas na política de aldeamentos: a vida política, as leis, os sacramentos e as cerimônias. Não desconsideramos a efetiva adoção de costumes indígenas, que, de fato, foi intensa e marcou profundamente a sociedade colonial. Gostaríamos apenas de destacar o fato que o conceito de selvagem era também mobilizado para interpretar ou descrever diferentes conflitos político-religiosos. 
CONSIDERAÇÕES FINAIS 
A “armadilha" envolvida em uma pesquisa que se volta à análise de uma prática discursiva e de seus condicionantes é fechar-se na ideia de que "um texto é apenas a prova de si próprio, das próprias categorias" ${ }^{334}$. A nossa dissertação concentrou-se justamente na análise das categorias e procedimentos formais que orientavam a atividade epistolográfica da Companhia de Jesus, mas teve como pressuposto resguardar a dimensão referencial destes textos. Em outras palavras, operamos com a convicção de que as cartas tinham algo a nos informar acerca da vida cotidiana dos colonos, por pouco que fosse, e não apenas do que os jesuítas escreveram a propósito dela. A essa altura, podemos estabelecer algumas relações entre as diversas partes do trabalho e tecer algumas considerações finais a respeito de duas questões principais: quais as relações concretas - políticas, religiosas e culturais - que estão compreendidas na utilização das categorias e formatos textuais em questão? $O$ que efetivamente a correspondência informa a respeito da vivência religiosa dos colonos a partir de nossa premissa epistemológica?

Comecemos pela segunda questão, tratada mais rapidamente, destacando um aspecto fundamental da natureza dessa documentação: a voz (ou vozes) nela presentes. Carlo Ginzburg debruçou-se sobre esse problema em relação à documentação inquisitorial. Esta documentação é fruto de um diálogo entre duas culturas distintas, a do inquisidor e a do acusado, com um evidente desequilíbrio de poder, real e simbólico ${ }^{335}$. A voz em desvantagem, contudo, pode ser identificada em algumas situações específicas em que o texto adquire um caráter mais acentuadamente dialógico. Um interrogatório é mais suscetível a tais situações, dada sua própria conformação, do que uma crônica, uma carta ou um tratado, mas, também nestes últimos, o caráter dialógico pode se manifestar de maneira indireta.

Um procedimento similar tem sido aplicado à documentação missionária, da qual fazem parte as cartas jesuíticas, por uma série de pesquisas voltadas ao processo de "mediação cultural" necessariamente desenvolvido no "encontro", também em desigualdade de forças, entre europeus e indígenas, como discutimos em nossa introdução ${ }^{336}$. O diálogo intercultural presente na correspondência jesuítica é entre missionários e indígenas. Não há (ou somente de forma muito indireta), por parte do missionário, o interesse analítico em relação aos costumes, crenças e características dos colonos portugueses, como há em relação ao indígena (mesmo que submetido a categorias prévias), à semelhança do que ocorre entre inquisidor e acusado.

\footnotetext{
${ }^{334}$ GINZBURG, Carlo. "O inquisidor como antropólogo: Uma analogia e as suas implicações”. In: . A micro-história e outros ensaios. Rio de Janeiro: Bertrand, 1991, pp. 203-14.

335 Ibid., 207-8.

336 Sem adentrar novamente esta discussão, indicamos aqui uma obra conjunta que sintetiza os principais elementos desenvolvidos por essa corrente: MONTERO, Paula (org.). Deus na Aldeia: missionários, índios e mediação cultural. São Paulo: Globo, 2006.
} 
Nesse sentido, procuramos, ao longo do trabalho, identificar sob quais condições a correspondência os descreve.

Sendo assim, não podemos considerar a descrição dos costumes gentílicos, rituais ou não, adotados pelos colonos como um elenco de práticas heterodoxas que os jesuítas estivessem buscando identificar e combater. São, antes de tudo, peças que compõem a imagem do civilizado que se torna selvagem, uma categoria interpretativa e retórica possível naquele contexto e mobilizada em diversas situações conflituosas, indissociavelmente religiosas e políticas. Apresentar os costumes gentílicos adotados por brancos ou mamelucos a partir das narrativas epistolares equivale a fazer uma analogia indireta entre estes textos, no que tange à presença de vozes de jesuítas e de colonos, e os processos inquisitoriais referentes aos "desvios" surgidos no contexto intercultural brasileiro, como é o caso da famosa Santidade de Jaguaripe, estudada mais pormenorizadamente por Ronaldo Vainfas ${ }^{337}$. A impressionante situação de ambivalência cultural dos mamelucos investigados neste processo, trafegando com relativa desenvoltura entre o âmbito português e indígena ${ }^{338}$, leva-nos imediatamente a conjecturar o que havia de concreto nas descrições de Anchieta e Nóbrega a respeito dos filhos de João Ramalho. Entretanto, individualizar o que é verdadeiro e o que é retoricamente construído naqueles trechos não pode evitar um caráter arbitrário. Ao aceitarmos o fato, verossímil, de que os mamelucos Ramalhos participassem de execuções rituais ou seu descaso para com a Inquisição, somos metodologicamente compelidos a também aceitar a acusação, bastante suspeita para uma época de ferrenha polêmica entre católicos e protestantes, de que os franceses calvinistas do Rio de Janeiro haviam se indianizado quase por completo. Delimitar essa lacuna e o campo do indecifrável, neste caso, é fundamental para não reservar ao historiador o papel de propagador de categorias de pensamento e indisposições políticas dos jesuítas.

O que esperamos ter demonstrado, em nossa análise, a respeito das relações culturais entre brancos, índios e mamelucos é que as cartas, cotejadas com as atas da Câmara, corroboram a tese de uma clivagem social para a configuração cultural do planalto, a despeito da persistência da ideia do predomínio da mestiçagem e hibridismo cultural em certa historiografia. Dito de outra forma: ainda que o objetivo dos missivistas fosse, muitas vezes, o de apresentar brancos e mamelucos conjuntamente como selvagens, as cartas contêm elementos não intencionais que possibilitam entrever a existência de um ambiente no qual a

\footnotetext{
${ }^{337}$ VAINFAS, Ronaldo. A heresia dos índios: catolicismo e rebeldia no Brasil colonial. São Paulo: Companhia das Letras, 1995.

${ }^{338}$ Ibid., pp. 141-51.
} 
identidade cristã (no sentido civilizacional) era mais claramente reconhecida, notadamente através das instituições municipais e religiosas. Por não ser propriamente o foco de nossa investigação, não procuramos abordar essa configuração social de maneira aprofundada, apenas esboçamos alguns elementos presentes nas cartas que podem apontar direcionamentos quanto ao tema. Pretendemos ter deixado claro, ainda, que o tema da mancebia recebia um cuidado analítico maior na correspondência, fruto da centralidade deste "pecado" dentre os vários que os jesuítas combatiam. Consideramos que se trata do ponto em que os colonos mais "se abriram" à influência local.

Quanto à questão das relações concretas envolvidas na utilização das categorias e formatos textuais da correspondência jesuítica, o resultado mais significativo é a constatação da ligação entre a indicação da "vida de selvagens" apontada para alguns portugueses e os elementos institucionais da vida civil, ligados à administração da vila e seus instrumentos. Viver em meio aos índios e viver como selvagem significava, fundamentalmente, viver alheio aos instrumentos civilizatórios europeus, dos quais não se pode dissociar o aspecto religioso (civil e doutrinário ao mesmo tempo) e o cultural. De onde se conclui que, nos códigos utilizados pelos jesuítas para interpretar a realidade colonial, dançar ao modo dos índios no Rio de Janeiro calvinista era mais selvagem que dançar do mesmo modo para propagar a "verdade" religiosa católica.

A atividade epistolográfica jesuítica, como a consideramos desde o início, não era um reflexo da atuação da ordem no Brasil, mas parte fundamental dela. Uma das maneiras como as cartas atuaram foi delimitando seu próprio ministério, sua própria política indígena, sua atividade econômica etc., como o espaço legítimo da verdade cristã, em oposição aos colonos e ao clero secular. O viés negativo com que o clero secular frequentemente figura na correspondência jesuítica brasileira está ligado ao processo de afirmação do "modo de proceder" da Companhia no seio da Igreja e para fora dela. A classificação da vivência religiosa dos colonos do planalto paulista como selvagem ou de maus cristãos, muito presente na correspondência jesuítica e na historiografia posterior, ainda que obscureça em alguma medida o quanto podemos compreender sobre as características efetivas desse cotidiano religioso, é bastante reveladora do processo por meio do qual a dimensão política da religião delimita o espaço da legitimidade de costumes e crenças determinados. 
BIBLIOGRAFIA 


\section{FONTES}

Archivum Romanum Societatis, Roma.

Brasile 2. "Memorial das cousas que o P. ${ }^{\mathrm{e}}$ Gregorio Sarraõ ha propuesto a N. P. ${ }^{\mathrm{e}}$ Geral cõ la respuesta de su Paternidad. año .76.", ff. 24-25.

Lusitania 69. Carta de Cristóvão de Gouveia, 19 de agosto de 1585, ff. 131-131v.

Carta de Cristóvão de Gouveia, 19 de agosto de 1585, ff. 133-134.

Carta de Cristóvão de Antônio Ferreira, 15 de março de 1585, ff. 53-54.

Actas da Camara da villa de S. Paulo, vol. I (1562-1596). Publicação official do Archivo Municipal de S. Paulo. São Paulo: Duprat \& C. ${ }^{\text {a }} 1914$.

"Actas da Camara de Santo André da Borda do Campo". In: TAUNAY, Afonso de E. João Ramalho e Santo André da Borda do Campo. São Paulo: Publicação comemorativa do Quarto Centenário da Fundação de Santo André da Borda do Campo, 1953, pp. 261-320.

ANCHIETA, José de, S.J. Cartas, Informações, Fragmentos Históricos e Sermões do Padre Joseph de Anchieta, S.J. (1554-1594). Rio de Janeiro: Civilização Brasileira, 1933.

ARMAS, Antonio Rumeu de. "Una carta inédita del apostol del Brasil, beato José de Anchieta, al rey Felipe II", Anuário de estudos Atlânticos, 43. Madrid/Las Palmas, 1997, pp. 469-500.

CARDIM, Fernão. Tratados da terra e gente do Brasil. Introduções e notas de Baptista Caetano, Capistrano de Abreu e Rodolpho Garcia. Rio de Janeiro: J. Leite \& Cia., 1925.

LEITE, Serafim, S.J. (org). Monumenta Brasiliae, v. I-IV. Roma, 1956-60.

LOYOLA, Inácio de. Gli scritti, A cura dei gesuiti della Provincia d’Italia. Roma: Edizioni Adp, 2007.

PROCESSO DE JOÃO DE BOLÉS E JUSTIFICAÇÃO REQUERIDA PELO MESMO (1560-1564), Anais da Biblioteca Nacional, 25, 1903, pp. 215-307.

SOUSA, Gabriel Soares de. "Capítulos que Gabriel Soares de Sousa deu em Madrid ao Sr. D. Cristovam de Moura contra os padres da Companhia de Jesus que residem no Brasil, com umas breves respostas dos mesmos padres que dêles foram avisados por um seu parente a quem os ele mostrou", Anais da Biblioteca Nacional, 62, 1940 [1587], pp. 347-381. 
. Tratado descriptivo do Brasil em 1587. Introdução e comentários de Francisco Adolpho de Varnhagen. Rio de Janeiro: Typographia de João Ignacio da Silva, 1879.

SOUSA, Tomé de. "Carta do governador Tomé de Sousa ao rei D. João III, com notícia das vilas e povoações que visitara na costa do Brasill", Cidade de Salvador, 1 de junho de 1553. In: SERRÃO, Joaquim Veríssimo. O Rio de Janeiro no século XVI, vol. II. Lisboa: Edição da Comissão Nacional das Comemorações do IV centenário do Rio de Janeiro, 1965, pp. 25-9.

VASCONCELOS, Simão de. Chronica da Companhia de Jesu do Estado do Brasil, vol. I. $2^{\mathrm{a}}$ ed. Lisboa: 1865 [1663].

\section{REFERÊNCIAS BIBLIOGRÁFICAS}

ABREU, Capistrano. Capítulos de História Colonial (1500-1800). Rio de Janeiro: M. Orosco \& C., 1907.

AGNOLIN, Adone. Jesuítas e Selvagens: A negociação da fé no encontro catequético-ritual americano-tupi (séc. XVI - XVII). São Paulo: Humanitas Editorial, 2007.

AMARAL, Antonio Barreto do. Dicionário de História de São Paulo. São Paulo: Imprensa Oficial, 2006 [1903].

BLAJ, Ilana. "Mentalidade e Sociedade: revisitando a historiografia sobre São Paulo colonial”, Revista de História da Universidade de São Paulo, n. 142-143, 1 sem. 2000, pp. 239-259.

- A trama das tensões: O processo de mercantilização de São Paulo colonial (16811721). São Paulo: Humanitas/FFLCH/USP: Fapesp, 2002.

BRELICH, A. "Prolegómenos a una historia de las religiones". In: PUECH, Henri-Charles (org.). Historia de las religiones, vol. 1: Las religiones antiguas I. 6 ed. Madrid: Siglo XXI, 1986, pp. 30-97.

BRUNO, Ernani Silva. História e tradições da cidade de São Paulo, vol. I: Arraial de sertanistas (1554-1828). Rio de Janeiro: Livraria José Olympio Editôra, 1953. 
CAMARGO, Paulo Florêncio da Silveira. A Igreja na História de São Paulo, Vol. I (15301624). São Paulo: Instituto Paulista de História e Arte Religiosa, 1952.

CASTILHO, Ataliba Teixeira de (org.). História do português paulista. Série Estudos, Vol. I. Campinas: Institutos de Estudos da Linguagem, 2009.

CERELLO, Adriana Gabriel. O livro nos textos jesuíticos do século XVI: edição, produção e circulação de livros nas cartas dos jesuítas na América Portuguesa (1549-1563). 2007. 143 f. Dissertação (Mestrado em Literatura Brasileira) - Faculdade de Filosofia, Letras e Ciências Humanas, Universidade de São Paulo, São Paulo, 2007.

CHAMBOULEYRON, Rafael. "A evangelização do Novo Mundo: O plano do Pe. Manuel da Nóbrega", Revista de História da Universidade de São Paulo, n. 134, 1 sem. 1996, pp. $37-47$.

CORREAA, Mariza."Repensando a Família Patriarcal Brasileira”. In: ALMEIDA, Maria Suely Kofcs et al. Colcha de Retalhos: Estudos sobre a Família no Brasil. São Paulo: Brasiliense, 1982, pp. 13-38.

EISENBERG, José. As missões jesuíticas e o Pensamento político moderno: Encontros culturais, aventuras teóricas. Belo Horizonte: Ed. UFMG, 2000.

FERRETTI, Danilo José Z. \& CAPELATO, Maria H.R. "João Ramalho e as Origens da Nação: os paulistas na comemoração do IV centenário da descoberta do Brasil", Revista Tempo, Dep. de História da UFF, v. 4, n. 8, dez/1999. Consulta em mar/2011. URL: http://www.historia.uff.br/tempo/artigos_dossie/artg8-4.pdf

FERRETTI, Danilo José Z. A construção da paulistanidade: identidade, historiografia e política em São Paulo (1856-1930). 2004. 391 f. Tese (Doutorado em História Social) Faculdade de Filosofia, Letras e Ciências Humanas, Universidade de São Paulo, São Paulo, 2004.

FEITLER, Bruno. Nas malhas da consciência: Igreja e Inquisição no Brasil: Nordeste 16401750. São Paulo: Alameda: Phoebus, 2007.

GINZBURG, Carlo. "O inquisidor como antropólogo: Uma analogia e as suas implicações". In: A micro-história e outros ensaios. Rio de Janeiro: Bertrand, 1991, pp. 20314. 
GLEZER, Raquel. Chão de terra e outros ensaios sobre São Paulo. São Paulo: Alameda, 2007.

HANSEN, João Adolfo. "O nu e a Luz: Cartas jesuíticas do Brasil. Nóbrega, 1549-1558”, Revista do Instituto de Estudos Brasileiros, São Paulo, n. 38, 1995, pp. 87-119.

"Para uma história dos conceitos das letras coloniais luso-brasileiras dos séculos XVI, XVII e XVIII”. In: FERES JÚNIOR, João; JASMIN, Marcelo (orgs.). História dos conceitos: diálogos transatlânticos. Rio de Janeiro: Editora PUC-Rio/ Edições Loyola/ IUPERJ, 2007.

HOLANDA, Sérgio Buarque de. "Movimentos da população em São Paulo em meados do século XVIII (sic)", Revista do IEB, n.1, 1966, pp. 55-111.

Caminhos e fronteiras. 3. ed. São Paulo: Companhia das Letras, 1994 [1956].

Raízes do Brasil. 26. ed. São Paulo: Companhia das Letras, 1995 [1936].

. "Capelas antigas de São Paulo", Revista do Serviço de Patrimônio Histórico Nacional, vol. 5, Rio de Janeiro, 1941.

KEHL, Luis Augusto Bicalho. Simbolismo e profecia na fundação de São Paulo: A casa de Piratininga. São Paulo: Editora Terceiro Nome, 2005.

KUHNEN, Alceu. As origens da Igreja no Brasil: 1500 a 1552. Bauru, SP: EDUSC, 2005.

LEITE, Serafim, S. J. História da Companhia de Jesus no Brasil, tomos I e II. Lisboa: Livraria Portugália; Rio de Janeiro: Civilização Brasileira, 1938.

MACHADO, Alcântara. Vida e morte do bandeirante. São Paulo: Imprensa Oficial do Estado de São Paulo, 2006 [1929].

MADRE DE DEUS, Frei Gaspar da. Memórias para a história da Capitania de S. Vicente, hoje chamada de S. Paulo, do Estado do Brazil. Lisboa: Tipographia da Academia, 1797.

MARQUES, Manuel Eufrásio de Azevedo. Apontamentos históricos, geográficos, biográficos, estatísticos e noticiosos da Província de São Paulo seguidos da cronologia 
dos acontecimentos mais notáveis desde a fundação da Capitania de São Vicente até o ano de 1876. São Paulo: Comissão do IV Centenário da cidade de São Paulo, 1954 [1879]. 2 tomos.

MASSENZIO, Marcello. A história das religiões na cultura moderna. São Paulo: Hedra, 2005.

MEIHY, José Carlos Sebe Bom. A presença do Brasil na Companhia de Jesus (1549-1649). 1975. 255 f. Tese (Doutorado em História Social) - Faculdade de Filosofia, Letras e Ciências Humanas, Universidade de São Paulo, São Paulo, 1975.

MOMIGLIANO, Arnaldo. "As origens da historiografia eclesiástica”. In: As raízes clássicas da historiografia moderna. Bauru, SP: EDUSC, 2004, pp. 187-212.

MONTEIRO, John Manuel. Negros da Terra: índios e bandeirantes nas origens de São Paulo. São Paulo: Companhia das Letras, 1994.

Tupis, Tapuias e historiadores: Estudos de História indígena e do indigenismo. 2001. 233 f. Tese (Livre Docência em Etnologia) - Instituto de Filosofia e Ciências Humanas, Unicamp, Campinas, 2001.

MONTERO, Paula (org.). Deus na Aldeia: missionários, índios e mediação cultural. São Paulo: Globo, 2006.

MORSE, Richard M. Formação histórica de São Paulo (de comunidade à metrópole). São Paulo: Difusão Européia do Livro, 1970 [1954].

MURPHY, James J. La retorica nel Medioevo: Uma storia delle teorie retoriche da s. Agostino al Rinascimento. Napoli: Liguore Editore, 1983.

NEMÉSIO, Vitorino. O campo de São Paulo: A Companhia de Jesus e o plano português do Brasil. $3^{a}$ ed. Lisboa: Secretaria de Estado da Informação e Turismo, 1971 [1954].

OLIVEIRA, José Joaquim Machado d'. Quadro Histórico da Província de São Paulo. São Paulo: Typographia Imparcial de J. R. A. Marques, 1864.

O’MALlEY, John W. Os primeiros jesuitas. Tradução Domingos Armando Donida. São Leopoldo, RS: Editora UNISINOS; Bauru, SP: EDUSC, 2004. 
PÉCORA, Alcir. "Arte das Cartas jesuíticas do Brasil". In: ENCONTRO INTERNACIONAL NÓBREGA-ANCHIETA, 1999, São Paulo. VOZ LUSÍADA. Anais do Encontro Internacional Nóbrega-Anchieta. São Paulo: Green Forest do Brasil, 1999, v. 1, p. 31-78.

PETRONE, Pasquale. Aldeamentos paulistas. São Paulo: Edusp, 1995.

POMPA, Cristina. Religião como tradução: missionários, Tupi e "Tapuia" no Brasil colonial. Bauru, SP: EUDSC, 2003.

PORTA, Paula (org.) História da Cidade de São Paulo, v.1: a cidade colonial. São Paulo: Paz e Terra, 2004.

PRADO Jr., Caio. "O fator geográfico na formação e no desenvolvimento da cidade de São Paulo". In: . Evolução política do Brasil e outros estudos. São Paulo: Editora Brasiliense, 1953, pp. 99-118.

PROSPERI, Adriano. "O missionário". In: VILLARI, Rosario (dir.). O homem barroco. Lisboa: Presença, 1995, pp. 145-171.

. "As missões no Brasil, vistas de Roma". Comunicação apresentada no Colóquio internacional Contextos missionários: Religião e poder no Império português, realizado na Universidade de São Paulo, 1-5 de outubro de 2007.

Revista trimensal do Instituto Histórico e Geográfico Brasileiro. Rio de Janeiro, tomo XL, parte II, 1877; tomo LXII, parte II, 1900.

Revista do Instituto Histórico e Geográfico de São Paulo, vol. VII, 1902; vol. IX, 1904.

RUIZ GONZALEZ, Rafael. A vila de São Paulo durante a união das coroas: estratégias políticas e transformações jurídicas. 2002. 229 f. Tese (Doutorado em História Social) Faculdade de Filosofia, Letras e Ciências Humanas, Universidade de São Paulo, São Paulo, 2002.

. "Colonos e jesuítas no planalto: A força dos usos e costumes na vila de São Paulo" In: CAMARGO, Ana Maria de A. São Paulo, uma longa história. São Paulo, CIEE, 2004, pp. 13-38.

SALVADOR, José Gonçalves. Cristãos-Novos, jesuítas e inquisição: Aspectos de sua 
atuação nas capitanias do Sul, (1530-1680). São Paulo: Livraria Pioneira Editora, 1969.

SANT'ANA, Nuto. "Festas religiosas e profanas". In: Ensaios paulistas: Contribuição de 'O Estado de São Paulo' às comemorações do IV Centenário da cidade. São Paulo: Anhambi, 1958, pp. 441-57.

SILVA, Janice Teodoro da. São Paulo: 1554-1880: discurso ideológico e organização espacial. São Paulo: Editora Moderna, 1984.

SILVA, Maria Beatriz Nizza da. Sistema de casamento no Brasil colonial. São Paulo: Editora da Universidade de São Paulo, 1984.

(org.) et al. História de São Paulo colonial. São Paulo: Editora UNESP, 2009.

SOUZA, Laura de Mello e. Inferno Atlântico: demonologia e colonização: séculos XVIXVIII. São Paulo: Companhia das Letras, 1993.

. "Vícios, virtudes e sentimento regional: São Paulo, da Lenda Negra à Lenda Áurea", Revista de História da Universidade de São Paulo, n. 142-143, 1 sem. 2000, pp. 261-276.

TAUNAY, Afonso de E. João Ramalho e Santo André da Borda do Campo. São Paulo: Publicação comemorativa do Quarto Centenário da Fundação de Santo André da Borda do Campo, 1953.

São Paulo nos primeiros anos (1554-1601): ensaio de reconstituição social; São Paulo no Século XVI: história da vila piratiningana. Coordenação de Paula Porta. São Paulo: Paz e Terra, 2003 [1920, 1921].

TORRES-LONDOÑO, Fernando. A outra família: Concubinato, Igreja e escândalo na Colônia. São Paulo: Edições Loyola, 1999.

. "Escrevendo Cartas. Jesuítas, Escrita e Missão no Século XVI", Revista Brasileira de História. São Paulo, v. 22, n 43, 2002, pp. 11-32

VAINFAS, Ronaldo. Casamento, amor e desejo no Ocidente cristão. São Paulo: Editora Ática, 1986.

. Trópico dos pecados: Moral, Sexualidade e Inquisição no Brasil. Rio de Janeiro: 
Campus, 1989.

- A heresia dos índios: catolicismo e rebeldia no Brasil colonial. São Paulo: Companhia das Letras, 1995.

"Moralidades brasílicas: deleites sexuais e linguagem erótica na sociedade escravista". In: SOUZA, Laura de Mello e (org.). História da vida privada no Brasil, vol. 1: Cotidiano e vida privada na América portuguesa. São Paulo: Companhia das Letras, 1997, pp. 221-273.

VILARDAGA, José Carlos. São Paulo na órbita do Império dos Felipes: Conexões castelhanas de uma vila da América portuguesa durante a União Ibérica (1580-1640). 2010. 399 f. Tese (Doutorado em História Social) - Faculdade de Filosofia, Letras e Ciências Humanas, Universidade de São Paulo, São Paulo, 2011.

ZERON, Carlos Alberto de M. R. Ligne de foi: La compagnie de Jésus et l'esclavage dans le processus de formation de la société coloniale en Amérique portugaise (XVIe-XVIIe siècles). Paris: Honoré Champion Éditeur, 2009. 